\title{
Demonstration of Entrained Solids and Sr/TRU Removal Processes with Archived AN-107 Waste
}

Richard T. Hallen

Kriston P. Brooks

Lynette K. Jagoda

July 2000

Prepared for

BNFL, Inc.

under contract W375-98-LC-4168

Battelle, Pacific Northwest Division

Richland, Washington 99352 


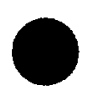

•

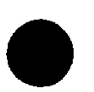




\section{DISCLAIMER}

This report was prepared as an account of work sponsored by an agency of the United States Government. Neither the United States Government nor any agency thereof, nor any of their employees, make any warranty, express or implied, or assumes any legal liability or responsibility for the accuracy, completeness, or usefulness of any information, apparatus, product, or process disclosed, or represents that its use would not infringe privately owned rights. Reference herein to any specific commercial product, process, or service by trade name, trademark, manufacturer, or otherwise does not necessarily constitute or imply its endorsement, recommendation, or favoring by the United States Government or any agency thereof. The views and opinions of authors expressed herein do not necessarily state or reflect those of the United States Government or any agency thereof. 


\section{DISCLAIMER}

Portions of this document may be illegible in electronic image products. Images are produced from the best available original document. 


\section{SUMMARY}

Waste from Hanford underground storage Tank 241-AN-107 is a candidate low-activity waste (LAW) for Envelope C. Envelope $\mathrm{C}$ wastes require pretreatment to remove entrained solids, radioactive strontium, transuranics, radioactive cesium, and technetium before immobilization. The initial baseline pretreatment process includes plans for entrained solids removal by crossflow filtration, $\mathrm{Sr} / \mathrm{TRU}$ precipitation with added strontium and iron, and $\mathrm{Sr} / \mathrm{TRU}$ precipitate removal by crossflow filtration. However, studies have shown that entrained solids and the $\mathrm{Sr} / \mathrm{Fe}$ precipitates were very difficult to filter from candidate Envelope $\mathrm{C}$ waste. An alternative pretreatment process being developed uses permanganate instead of iron. Permanganate treatment has been shown to be effective for decontaminating waste from Hanford Tank SY-101.

Small-scale experiments with archived AN-107 waste were conducted by Battelle to determine the effectiveness of the permanganate treatment process. These tests were conducted in three rounds of experiments. The early tests showed that permanganate treatment alone would provide adequate TRU removal, however, it would not provide adequate $\mathrm{Sr}$ removal. The second set of experiments showed the preferred $\mathrm{Sr}$ /TRU removal process involved addition of strontium and permanganate. Because the composition of the archived waste had been altered by past pretreatment tests (diluted and removal of cesium and settled solids), the final set of experiments included tests with actual AN-107 diluted feed. These tests identified conditions that should provide adequate $\mathrm{Sr} / \mathrm{TRU}$ decontamination.

The work reported here was conducted to evaluate process conditions with two, 1-L batches of archived AN-107, which provided a volume of waste large enough for crossflow filtration studies. One, 1-L sample of archived waste was adjusted to $1 \mathrm{M}$ hydroxide and used for entrained solids removal tests. Following this test, Sr/TRU removal was accomplished by addition of a strontium nitrate solution followed by sodium permanganate solution. The resulting precipitate was used for crossflow filtration tests to demonstrate the performance of a 0.1-um filter element.

Even though many of the entrained solids were removed from the archived AN-107 sample by previous pretreatment testing (settle/decant and deep bed filtration from the ion exchange column), crossflow filtration was found to be impractical to remove the remaining solids due to very low filtrate flux rates $\left(0.0079 \mathrm{gpm} / \mathrm{ft}^{2}\right)$. Therefore, $\mathrm{AN}-107$ waste was treated for $\mathrm{Sr} / \mathrm{TRU}$ removal with the entrained solids present. The entrained solids were then removed along with the $\mathrm{Sr} / \mathrm{TRU}$ precipitate, in a single filtration step. Crossflow filtration tests were conducted in the Cell Unit Filter (CUF) system with the Sr/TRU precipitated waste. The filterability of archived AN-107, as determined by filter flux rate, increased by an order of magnitude after the pretreatment process (average of $0.11 \mathrm{gpm} / \mathrm{ft}^{2}$ ). The pretreated waste could be effectively filtered by crossflow filtration.

Results were obtained from experiments with archived AN-107 samples treated at two different target reagent concentrations, $1 \mathrm{M}$ hydroxide, $0.075 \mathrm{M}$ strontium, and $0.05 \mathrm{M}$ permanganate, and $0.8 \mathrm{M}$ hydroxide, $0.05 \mathrm{M}$ strontium, and $0.03 \mathrm{M}$ permanganate. Approximately $1-\mathrm{L}$ of archived AN-107 were treated in each experiment. Decontamination of strontium-90 and TRU (primarily 
Am-241) in the supernatant was greater than needed to meet the immobilized low-activity waste (ILAW) requirements (less than $100 \mathrm{nCi} / \mathrm{g}$ TRU and less than $20 \mathrm{Ci} / \mathrm{m}^{3} \mathrm{Sr}-90$ in the final ILAW). The target DFs were 10 for Sr-90 and 5 for Am-241. The stronium-90 decontamination factors (DFs) obtained were consistently greater than 20 and the Am-241 DF was 10 and greater. Removal of Eu isotopes 154 and 155 was slightly less than the Am DFs. These DFs include the contribution from the removal of the entrained solids although this was relatively small. The removal of the entrained solids accounted for very little $\mathrm{Sr}-90$ removal and about $10 \%$ of the DF for Am-241 because the archived waste samples had most of the solids already removed. 


\section{CONTENTS}

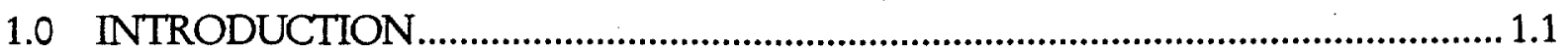

2.0 TEST CONDITIONS AND EXPERIMENTAL PROCEDURES.................................. 2.1

2.1 Description of Archived AN-107 Sample .................................................................. 2.1

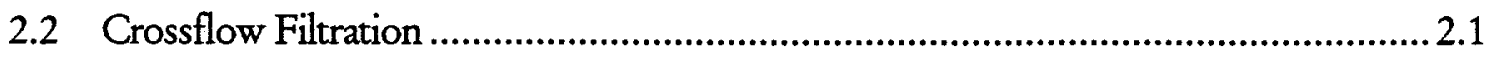

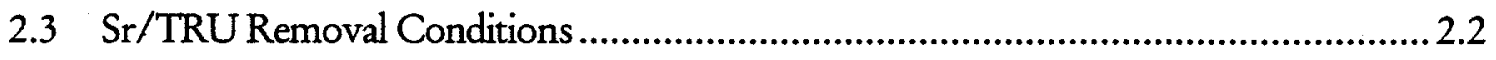

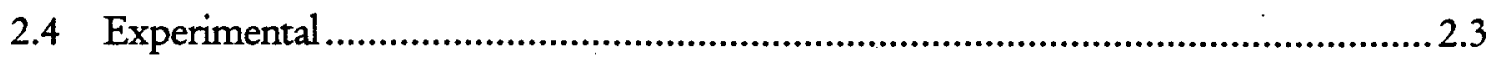

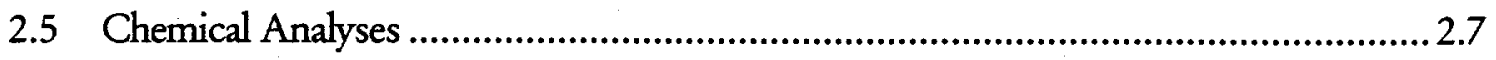

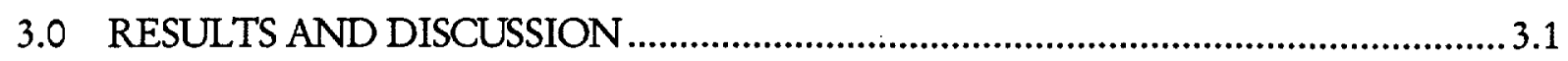

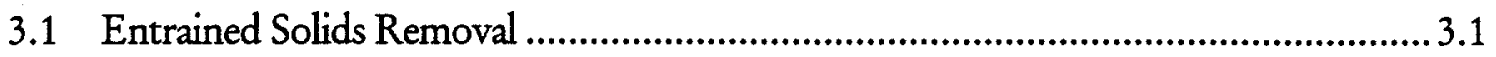

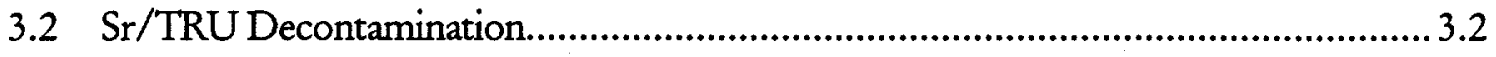

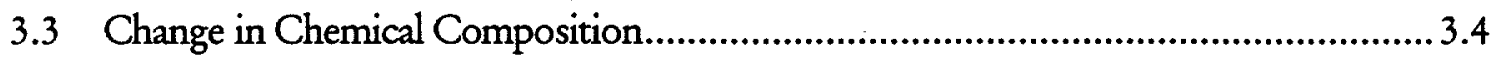

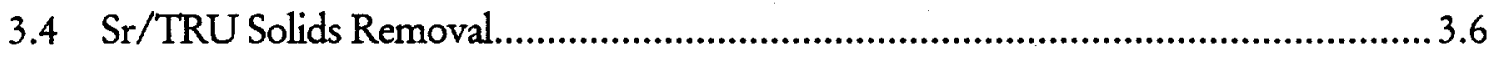

4.0 CONCLUSIONS AND RECOMMENDATIONS .................................................... 4.1

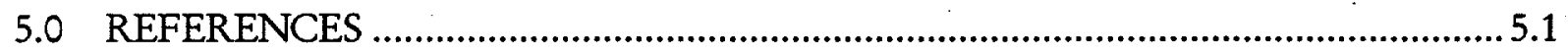

APPENDIX A: TEST INSTRUCTION-041, DATA SHEETS, AND LOG BOOK

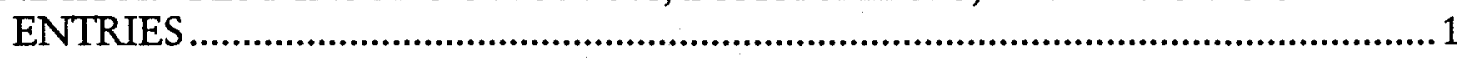

APPENDIX B: TEST INSTRUCTION-063 AND LOG BOOK ENTRIES ...............................

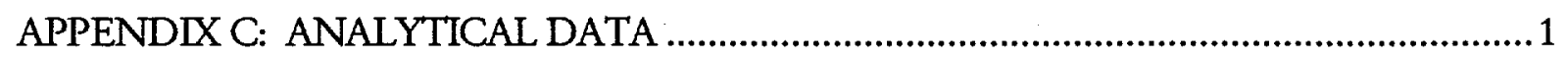

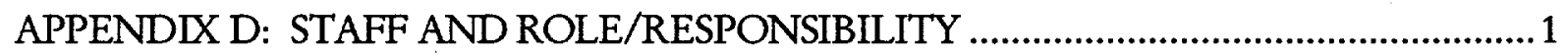




\section{FIGURES}

Figure 2.1. Flow Chart of Archive AN-107.

Figure 3.1. Comparison of the Filtrate Flux for Entrained Solids and Sr/TRU

Precipitate/Entrained Solids Removal from Archived AN-107 Waste at Target

Conditions of $55 \mathrm{psi}$ TMP and $12.2 \mathrm{ft} / \mathrm{s}$ Crossflow Velocity .

Figure 3.2. Volume-Weighted Particle Size Distribution Comparison Between Archive AN-107 Entrained Solids and Sr/TRU Precipitate.

Figure 3.3. Average Filtrate Flux for Conditions Tested With the Archived AN-107 $\mathrm{Sr} /$ TRU Precipitate

Figure 3.4. Particle Size Distribution Comparison of Archive AN-107 Sr/TRU

Precipitate With and Without Sonication.

\section{TABLES}

Table 2.1. Sr/TRU Target Concentrations and Volume for the Two Experiments Conducted with Archived AN-107

Table 2.2. Test Conditions Studied for Entrained Solids Removal from Archived AN-107 .... 2.4

Table 2.3. Test Conditions Studied With Archive AN-107 Sr/TRU Solids Removal ............... 2.5

Table 2.4. Samples and Their Required Analyses.................................................................... 2.6

Table 2.5. Samples and Their Required Analyses...................................................................... 2.6

Table 3.1. Samples and Mass Dilution for Calculating Decontamination Factors .................... 3.2

Table 3.2. Strontium, Am, and Eu Decontamination Factors for Samples MN-22 to MN32 and the Composition of Composite CUF Filtrate (MN-32).

Table 3.3. Samples and Mass Dilution for Calculating Decontamination Factors ...................... 3.3

Table 3.4. Radioactive Element Decontamination Factors and Composition of Filtrate (MR-03)

Table 3.5. Concentration of Major ICP Metals in Samples MN-21 to MN-32 and Sample Density (data not corrected for sample dilution from added reagents)

Table 3.6. Concentration of Major ICP Metals in Samples MR-01 to MR-03 (data not

corrected for sample dilution from added reagents). 3.5 


\subsection{INTRODUCTION}

BNFL Inc. was awarded the Privatization Contract for treatment of Hanford underground storage tank wastes as part of the River Protection Project-Waste Treatment Plant (RPP-WTP). In Part B-1, Battelle is conducting technology development and demonstration of process flowsheet steps for BNFL. Entrained solids removal by crossflow filtration is the first proposed process step in pretreatment. Filtration should remove sufficient solids to prevent plugging of the ion exchange columns downstream and to ensure that insoluble radioactive strontium and transuranic isotopes (TRU) are removed. These solids are then to be concentrated and returned to the U.S. Department of Energy (DOE). The RPP-WTP Privatization Contract (2000) specifies certain isotopic, chemical, and physical limits for the entrained solids returning to the DOE double-shell tanks.

Three candidate low-activity waste types have been identified: Envelope A, Envelope B, and Envelope C. Treatment and disposal of the liquid (supernatant) fraction of Envelope $C$ wastes, such as Tank 241-AN-107, requires additional treatment to remove transuranics and radioactive strontium. Because of the high concentration of organic complexants in this waste (Complexant Concentrate waste), conventional separation processes (e.g., ion exchange) are not effective.

During Part A-1 of privatization, Savannah River Technical Center (SRTC) developed a Sr/TRU removal process involving isotopic dilution and precipitation with added strontium and iron (SRTC 1997a, 1997b, 1997c, and 1997d). While this treatment process provided the necessary supernatant decontamination, the resulting precipitate could not be filtered. The search began for an alternate treatment process. Battelle proposed permanganate be examined as an alternative, because it had been demonstrated to work with waste from Hanford Tank SY-101, which also contained high levels of organic complexants (Orth et al. 1995).

Permanganate has been examined as an oxidant for complexing agents (Orth et al. 1995), solubilizing chromium (Rapko et al. 1995, Rapko 1998), and oxidation of technetium species to pertechnetate (Schroeder et. al 1998) in tank wastes. Permanganate was found to oxidize chromium first, then organic carbon, and lastly nitrite. For wastes such as Tank SY-101, the chromium in the sludge consumes as much as half the permanganate. Orth et al. recommended permanganate doses of $0.1 \mathrm{M}$ for decomplexing SY-101 type wastes. At this level of permanganate, decontamination factors (DF) of $>143$ were obtained for $\mathrm{Sr}$ and 28.5 for $\mathrm{Pu}$. $\mathrm{AN}-107$ does not have the high chromium values in the sludge so permanganate is expected to be effective at lower concentrations.

Permanganate is also used as a precursor to $\mathrm{MnO}_{2}$ and/or $\mathrm{Mn}(\mathrm{OH})_{2}$ coprecipitants via the "Method of Appearing Reagents" (Krot et al. 1996). The method of appearing reagents requires the addition of a reductant to the waste to be treated. However, for Hanford wastes this is not necessary because reductants are already present in the waste. The resulting solids are effective coprecipitants for $\mathrm{Pu}$ and other TRU elements but generally not as effective as iron precipitates. Decontamination factors of greater 100 have been reported for various simulated waste streams.

The objective of this work was to demonstrate the entrained solids and Sr/TRU removal processes with archived AN-107 waste before proceeding with the integrated processing of AN107 diluted feed. Similar to entrained solids removal tests for AW-101 (Brooks et. al 1999), tests 
were planned to determine the permeability of an Envelope $C$ feed through a single element filter as a function of transmembrane pressure, axial velocity, solids concentration, and time. The archived AN-107 waste was used to demonstrate the treatment scheme for $\mathrm{Sr} / \mathrm{TRU}$ removal developed from small-scale tests conducted at Battelle with waste simulants and actual waste involving strontium and permanganate addition. Supernatant decontamination data were obtained from two treatment levels; $0.075 \mathrm{M} \mathrm{Sr}$ and $0.05 \mathrm{M}$ permanganate, and $0.05 \mathrm{M} \mathrm{Sr}$ and $0.03 \mathrm{M}$ permanganate. Crossflow filtration tests were conducted with waste treated with $0.075 \mathrm{M}$ $\mathrm{Sr}$ and $0.05 \mathrm{M}$ permanganate to determine the efficiency for $\mathrm{Sr} / \mathrm{TRU}$ solids removal. In addition, the efficiency of back pulse and chemical cleaning on the filter performance was evaluated. The chemical and radiochemical composition of the supernatant and filtrates were measured to determine efficiency of the Sr/TRU removal process.

This report contains the results of entrained solids removal, $\mathrm{Sr} / \mathrm{TRU}$ decontamination, and $\mathrm{Sr} / \mathrm{TRU}$ solids removal testing conducted at Battelle with archived AN-107 waste. Test conditions and experimental procedures are described in Section 2.0. Results from entrained solids removal and treatment with added $\mathrm{Sr}$ and permanganate are described in Section 3.0. The major conclusion and recommendations that evolved from this work are given in Section 4.0. The appendices contain the test instruction, data sheets, logbook entries, analytical data, calculation, and staff role/responsibilities for this work. 


\subsection{TEST CONDITIONS AND EXPERIMENTAL PROCEDURES}

The conditions for conducting the entrained solids and $\mathrm{Sr} / \mathrm{TRU}$ removal tests were detailed in $\mathrm{Sr}$ /TRU Precipitation and Ultrafiltration Test Specification (Townson 1998) issued by BNFL. The Test Specification was used to prepare a Test Plan (TP 29953-013) that described the general requirements for the $\mathrm{Sr} / \mathrm{TRU}$ removal tests to be conducted at Battelle. The actual test was conducted in accordance with Test Instruction-29953-041, which was specific to the $\mathrm{Sr}$ /TRU Removal test described in this report for archived AN-107. Deviations from the test instructions were necessary. The additional $\mathrm{Sr} / \mathrm{TRU}$ precipitation experiment was conducted in accordance with Test Instruction-29953-063.

\subsection{Description of Archived AN-107 Sample}

The archived AN-107 material used for this test was collected, diluted, settled solids removed, and cesium ion exchanged prior to its use for the BNFL project (Hendrickson 1997). It was collected as 45 grab samples in 125-mL bottles taken during January 1997. Approximately 5.4 liters of tank waste was then transferred to 222-S laboratory and $0.53 \mathrm{M}$ sodium hydroxide was added to dilute the waste to $5 \mathrm{M}$ sodium and to a free hydroxide concentration of $0.24 \mathrm{M}$. The supernatant was not filtered prior to cesium ion exchange. Instead, the solids were allowed to settle and the supernatant was decanted and sent through the crystalline silicotitanate loaded columns. Analysis of the waste after cesium removal indicated the free hydroxide to be $0.126 \mathrm{M}$. Following cesium removal the sample was transferred to PNNL in five 1-L poly bottles where it has been stored in the Shielded Analytical Laboratory (SAL) hot cells in the Radiochemical Processing Laboratory (RPL).

In June 1999, one liter of this archive AN-107 (1242.62 g) was adjusted with $\mathrm{NaOH}$ pellets to achieve a target concentration of $1 \mathrm{M}$ free hydroxide. This material was then transferred to the High-Level Radiochemistry Facility (HLRF) hot cells and placed into the CUF system for entrained solids removal testing.

\subsection{Crossflow Filtration}

The River Protection Project Waste Treatment Plant (RPP-WTP) (1996) flowsheet uses crossflow filtration as the solid/liquid separation technique. Unlike traditional dead-end filtration, which has a declining filtration rate caused by the growth of a filter cake on the surface of the filter medium, in cross-flow filtration, the filter cake is swept away by the fluid flowing across it. This filtration method is especially beneficial when there are very fine particles and when system simplicity is required.

One of the applications of crossflow filtration is to remove the entrained solids from the waste. The filtration should remove sufficient solids to prevent plugging of the ion exchange column downstream and to ensure that insoluble Sr-90 and transuranic isotopes are removed. Another application of crossflow filtration for Envelope $\mathrm{C}$ wastes is to remove the $\mathrm{Sr} / \mathrm{TRU}$ precipitate from the treated supernatant. The proposed flowsheet for Envelope $\mathrm{C}$ waste shows two sequential solids removal steps: First removal of the entrained solids, then $\mathrm{Sr}$ /TRU solids removal after $\mathrm{Sr}$ and permanganate treatment. 
Crossflow filtration tests were conducted in the HLRF hot cells with the Cell Unit Filter (CUF) system. The CUF had the following specifications:

- Mott sintered stainless steel filter, 0.1 micron rating, 24 in. long and 3/8 in. internal diameter (total area $0.196 \mathrm{ft}^{2}$ )

- Re-circulation flow with a maximum linear crossflow velocity of $16.4 \mathrm{ft} / \mathrm{s}$ along the axis of the filter

- Maximum transmembrane pressures of $80 \mathrm{psi}$

- Temperature control of $25 \pm 5^{\circ} \mathrm{C}$ during operation.

The system was fabricated based on modifications of the CUF system designed by SRTC. It is described in detail in Brooks et al. (1999). Unlike that used for the AW-101 testing, the filter used in this work was a Mott $0.1 \mu \mathrm{m}$-rated filter designed specifically for liquid service. Conditions for filtration tests were specified in Test Instruction 29953-041, Appendix A.

\subsection{Sr/TRU Removal Conditions}

Supernatant from Envelope $C$ waste contains $\mathrm{Sr}-90$ and TRU levels that are too high to meet immobilized low-activity waste (ILAW) requirements. The BNFL targets for ILAW are less than $100 \mathrm{nCi} / \mathrm{g}$ TRU and less than $20 \mathrm{Ci} / \mathrm{m}^{3} \mathrm{Sr}-90$ in the final ILAW. For AN-107 waste, this translates to target decontamination factors (DF) of approximately 10 for strontium $(90 \%$ removal) and 5 for TRU ( $80 \%$ removal). Since over $90 \%$ of the TRU in AN-107 is due to Am241, a decontamination factor of 5 was established for Am-241.

Experimental conditions for Sr/TRU removal were determined based on results from smallscale batch experiments with archived AN-107 waste (Hallen et al. 2000). The hydroxide concentration was increased by the addition of sodium hydroxide as solid pellets or 19M (50 wt\%) solution. Strontium nitrate and sodium permanganate were added as $1 \mathrm{M}$ solutions. The results from the small-scale experiments suggested that adequate $\mathrm{Sr} / \mathrm{TRU}$ removal could be obtained at a hydroxide concentration as low as $0.5 \mathrm{M}$ and reagent concentrations as low as $0.05 \mathrm{M}$ strontium and $0.03 \mathrm{M}$ permanganate for the archived AN-107 sample. But conservative conditions were chosen for the filtration tests, $1 \mathrm{M}$ hydroxide and reagent concentrations of $0.075 \mathrm{M}$ for strontium and $0.05 \mathrm{M}$ for permanganate, because the AN-107 diluted feed was more concentrated and contained more entrained solids than the archived waste. As part of an effort to prepare feed for sulfate removal tests, a later $\mathrm{Sr}$ /TRU removal experiment was conducted with archived AN-107 adjusted to $0.8 \mathrm{M}$ hydroxide and reagent concentrations of $0.05 \mathrm{M}$ strontium and $0.03 \mathrm{M}$ permanganate. This later sample was not tested in the CUF. Target compositions and volumes are shown in Table 2.1 for both experiments 
Table 2.1. Sr/TRU Target Concentrations and Volume for the Two Experiments Conducted with Archived AN-107

\begin{tabular}{|l|c|c|c|c|c|}
\hline $\begin{array}{c}\text { High } \\
\text { Conc. }\end{array}$ & $\begin{array}{c}\text { Target } \\
\text { Concentration } \\
(\mathbf{M})\end{array}$ & $\begin{array}{c}\text { Target } \\
\text { Volume } \\
(\mathbf{L})\end{array}$ & $\begin{array}{c}\text { Low } \\
\text { Conc. }\end{array}$ & $\begin{array}{c}\text { Target } \\
\text { Concentration } \\
(\mathbf{M})\end{array}$ & $\begin{array}{c}\text { Target } \\
\text { Volume } \\
(\mathbf{L})\end{array}$ \\
\hline initial waste & - & 0.82 & initial waste & - & 1.00 \\
\hline $\mathrm{NaOH}$ & 1 & 0.88 & $\mathrm{NaOH}$ & 0.8 & 1.05 \\
\hline $\mathrm{Sr}\left(\mathrm{NO}_{3}\right)_{2}$ & 0.075 & 0.95 & $\mathrm{Sr}\left(\mathrm{NO}_{3}\right)_{2}$ & 0.05 & 1.11 \\
\hline $\mathrm{NaMnO}_{4}$ & 0.05 & 1.00 & $\mathrm{NaMnO}_{4}$ & 0.03 & 1.14 \\
\hline
\end{tabular}

\section{$2.4 \quad$ Experimental}

All Sr/TRU and solids removal tests were performed in shielded process cells located in the RPL at Hanford. The CUF system, located in the HLRF, was used for entrained solids and $\mathrm{Sr} / \mathrm{TRU}$ precipitate removal tests. Test Instruction 29953-041, Appendix A, was used to conduct the entrained solids removal test, $\mathrm{Sr} / \mathrm{T} R U$ removal at high reagent concentration, and $\mathrm{Sr} / \mathrm{TRU}$ solids removal test. These tests were conducted from July 16 to July 28,1999 . The flowsheet describing these tests is shown in Figure 2.1.

Efforts were made prior to beginning this testing to ensure that clean water fluxes equal to or greater than the original factory specification were achieved. To do this, the pump and filter were changed out and remaining particulates were removed from the CUF by recirculating a side-stream through a $0.05 \mu \mathrm{m}$-rated cartridge filter. The clean water flux was then measured over the course of one hour. During this time, the average filtrate flux was $0.98 \mathrm{gpm} / \mathrm{ft}^{2}$ at 20 psi pressure differential and an axial velocity of $11.6 \mathrm{ft} / \mathrm{s}$. The clean water flux did not decline during this time. Following the hour long testing at 20 psid, the filter was tested at 10 and 30 psid for 20 minutes each. The filtrate flux remained relatively constant at 0.395 and 1.41 $\mathrm{gpm} / \mathrm{ft}^{2}$, respectively. These values were above the Mott reported values of $0.37 \mathrm{gpm} / \mathrm{ft}^{2}$ for 10 psid and $0.72 \mathrm{gpm} / \mathrm{ft}^{2}$ for 20 psid. The deionized water was drained from the system. It is estimated that approximately $100 \mathrm{~mL}$ of deionized water remained in the CUF after draining. This residual water diluted the archived AN-107 sample by roughly $10 \%$.

The entrained solids were tested in the CUF under two conditions rather than the original 6 point matrix due to low filtrate fluxes. If the filtrate flow were less than $10 \mathrm{~mL} / \mathrm{min}$ during the test, BNFL had specified that the test should be discontinued, the filter should be backpulsed, and a new condition should be tested. By stopping the test prematurely, unnecessary data would not be taken and further filter fouling would be prevented. The test conditions studied are shown in Table 2.2. When the flux was found to be very low for the first condition, two backpulses were attempted. Because of the low filtrate flux, only a small quantity of material could be collected in the backpulse chamber and two short backpulses were performed. A higher pressure was then tested to see if an increased flux were possible. Once again, the filtrate flux was excessively low and the test was discontinued. The entrained solids and filtrate were drained from the CUF and placed back into the original container. Samples were taken during the entrained solids removal test but were not analyzed. 


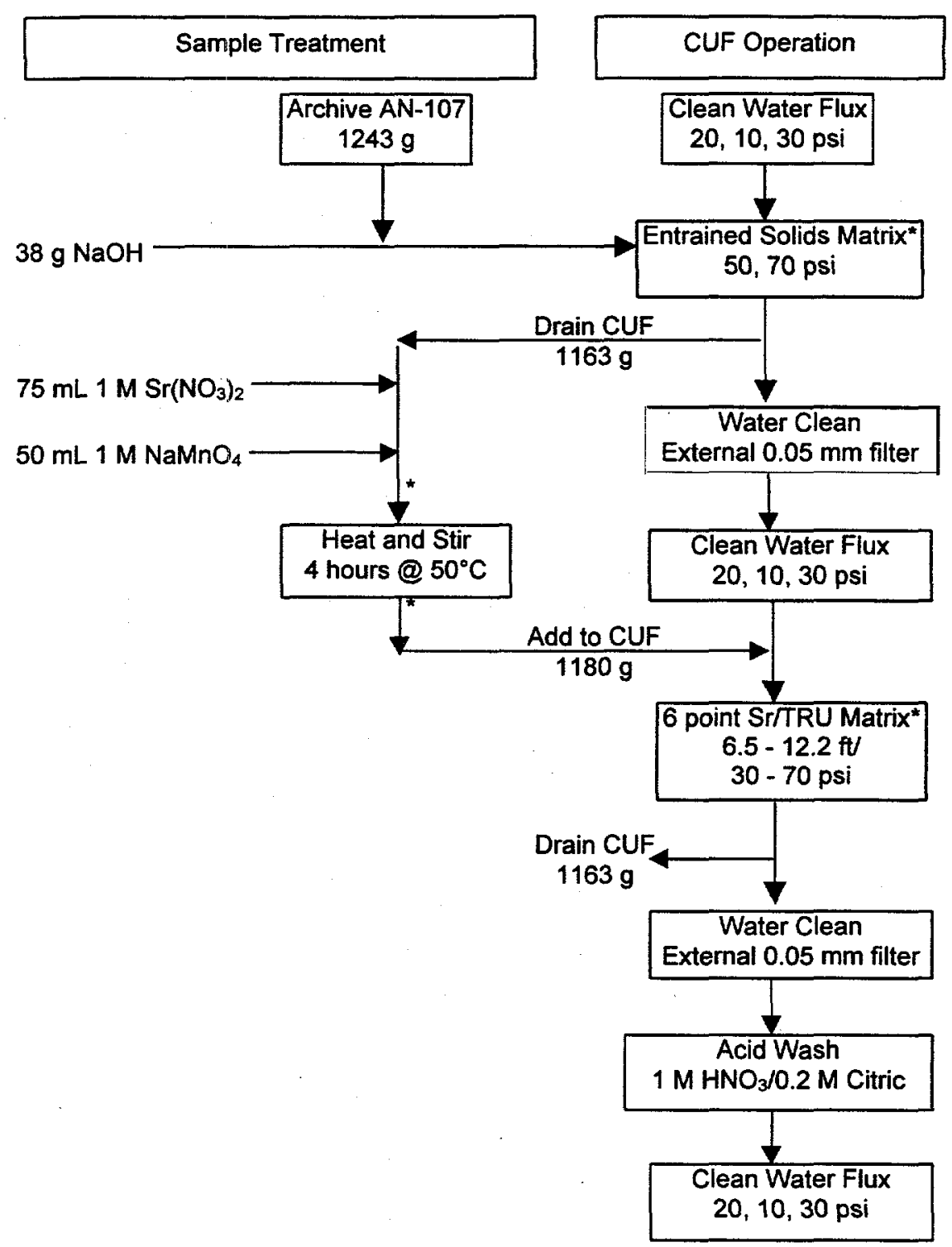

* Samples of filtrate or slurry were taken.

Figure 2.1. Flow Chart of Archive AN-107

Table 2.2. Test Conditions Studied for Entrained Solids Removal from Archived AN-107

\begin{tabular}{|c|c|c|}
\hline Condition & $\begin{array}{c}\text { Crossflow Velocity } \\
(\mathrm{ft} / \mathrm{s})\end{array}$ & $\begin{array}{c}\text { Transmembrane Pressure } \\
(\mathrm{psi})\end{array}$ \\
\hline 1 & 12.2 & 55 \\
\hline 3 & 9.3 & 70 \\
\hline
\end{tabular}


The CUF was drained, rinsed once with $0.2 \mathrm{M} \mathrm{NaOH}$, and then rinsed and the filter backpulsed multiple times with DI water to achieve a neutral $\mathrm{pH}$. Once neutral conditions were reached, a $0.05 \mu \mathrm{m}$ cartridge filter was attached to the CUF and the remaining particulate matter was removed. Clean water fluxes were measured and found that the original fluxes had been recovered. The system was drained in preparation for filtration of the $\mathrm{Sr} / \mathrm{TRU}$ precipitate. Once again approximately $100 \mathrm{~mL}$ of DI water left in the.CUF further diluted the archived AN-107 during the $\mathrm{Sr} / \mathrm{TRU}$ precipitation filtration test.

The archived AN-107 sample was transferred to an Erlinmeyer flask and placed on a stir plate. The sample was not heated to $50^{\circ} \mathrm{C}$ before reagent addition as originally specified in the Test Specification. Small-scale test had shown higher DFs when the reagents were added at ambient temperature, then digested after the addition was complete. At ambient cell temperature, approximately $75 \mathrm{~mL}$ of a $1 \mathrm{M}$ solution of $\mathrm{Sr}\left(\mathrm{NO}_{3}\right)_{2}$ was added to the archived $\mathrm{AN}-107$ sample over the course of 5 minutes. The original solution was dark brown, but during addition, white precipitate could be seen forming. Approximately 30 minutes later $50 \mathrm{~mL}$ of a $1 \mathrm{M}$ solution of $\mathrm{NaMnO}_{4}$ was added to the archived AN-107 sample over the course of 4 minutes. These quantities were added to produce target concentrations of $0.075 \mathrm{M} \mathrm{Sr}$ and $0.05 \mathrm{M}$ permanganate in the final treated sample. The slurry was then heated to $50^{\circ} \mathrm{C}$ with constant stirring and remained at temperature for 4 hours. The slurry was allowed to cool overnight and then it was added to the CUF for filtration testing.

Six conditions were tested with the $\mathrm{Sr} / \mathrm{TRU}$ precipitated, archived AN-107 sample in the CUF. The conditions are shown in Table 2.3. It was not possible to maintain the target flows at the required pressures. This may be due to the higher viscosity associated with the $\mathrm{Sr} / \mathrm{TRU}$ precipitate or pump stator wear.

Table 2.3. Test Conditions Studied With Archive AN-107 Sr/TRU Solids Removal

\begin{tabular}{|c|c|c|}
\hline Condition & $\begin{array}{c}\text { Crossflow Velocity } \\
(\mathrm{ft} / \mathrm{s})\end{array}$ & $\begin{array}{c}\text { Transmembrane Pressure } \\
(\mathrm{psi})\end{array}$ \\
\hline 1 & 11.2 & 53 \\
\hline 2 & 11.8 & 38 \\
\hline 3 & 8.1 & 70 \\
\hline 4 & 9.1 & 55 \\
\hline 5 & 6.4 & 54 \\
\hline 6 & 10.0 & 54 \\
\hline
\end{tabular}

During the course of testing, samples of the slurry and filtrate were taken for chemical and radiochemical analysis. Slurry samples were taken before $\mathrm{Sr}\left(\mathrm{NO}_{3}\right)_{2}$ and $\mathrm{NaMnO}_{4}$ addition and after the 4 hour heating and subsequent cooling of the $\mathrm{Sr} / \mathrm{TRU}$ precipitate. Filtrate samples were taken during each of the 6 conditions. Two slurry samples were also taken after Condition 3 and at the end of the CUF testing. Not all samples taken were analyzed. A filtrate composite sample, MN-32, was made of filtrate samples taken during each test condition and analyzed. The sample identification and analyses performed on each sample are shown in Table 2.4. 
Table 2.4. Samples and Their Required Analyses

\begin{tabular}{|c|c|c|c|c|}
\hline $\begin{array}{l}\text { Sample } \\
\text { Description }\end{array}$ & $\begin{array}{l}\text { Sample ID } \\
\text { Number }\end{array}$ & $\begin{array}{l}\text { Sample } \\
\text { Type }\end{array}$ & $\begin{array}{c}\text { Sample } \\
\text { Preparation }\end{array}$ & Analytes \\
\hline $\begin{array}{l}\text { Waste after } \\
\text { entrained solids } \\
\text { test (initial waste) }\end{array}$ & $\overline{\mathrm{MN}-21}$ & Slurry & $\begin{array}{l}0.45 \text { um filter, } \\
\text { acid digest }\end{array}$ & $\mathrm{Sr}-90, \mathrm{Am}-241, \mathrm{Na}, \mathrm{OH}^{-}$ \\
\hline $\begin{array}{l}\text { Waste after } \\
\text { Sr/TRU Removal } \\
\text { Treatment }\end{array}$ & $\overline{M N-22}$ & Slurry & $\begin{array}{l}0.45 \text { um filter, } \\
\text { acid digest }\end{array}$ & $\mathrm{Sr}-90, \mathrm{Am}-241, \mathrm{Na}, \mathrm{OH}^{-}$ \\
\hline $\begin{array}{l}1^{\text {st }} \text { CUF Permeate } \\
\text { Sr/TRU Solids } \\
\text { Removal }\end{array}$ & $\mathrm{MN}-23$ & Filtrate & acid digest & Sr-90, Am-241, Na \\
\hline Final CUF Slurry & MN-28 & Slurry & acid digest & Sr-90, Am-241, Na \\
\hline $\begin{array}{l}\text { Final CUF } \\
\text { Permeate }\end{array}$ & MN-31 & Filtrate & acid digest & Sr-90, Am-241, Na \\
\hline $\begin{array}{l}\text { Composite CUF } \\
\text { Permeate }\end{array}$ & $\overline{\mathrm{MN}-32}$ & Filtrate & acid digest & Sr-90, Am-241, Na \\
\hline
\end{tabular}

Test Instruction 29953-063 (see Appendix B) was used to conduct the Sr/TRU removal experiment at low reagent concentration. This experiment was conducted on October 26, 1999, to prepare $\mathrm{Sr} / \mathrm{TRU}$ treated waste for sulfate removal scoping tests. Starting with 1-L of archived AN-107 waste, $48 \mathrm{~mL}$ of $50 \mathrm{wt} \%(19 \mathrm{M}) \mathrm{NaOH}$ was added to give a calculated free hydroxide concentration of $0.8 \mathrm{M}$. A $50-\mathrm{mL}$ sample of caustic adjusted waste was removed for analyses (MR-01 and MR-02) and density determination. Then at ambient cell temperature, $57 \mathrm{~mL}$ of $1 \mathrm{M}$ $\mathrm{Sr}\left(\mathrm{NO}_{3}\right)_{2}$ was added with stirring over $6 \mathrm{~min}$. The solution was stirred for an additional $9 \mathrm{~min}$ before adding $34 \mathrm{~mL}$ of $1 \mathrm{M} \mathrm{NaMnO}_{4}$ over $6 \mathrm{~min}$. The waste was stirred for an additional 30 min before heating to $50^{\circ} \mathrm{C}$ and held there for 4 hours. After cooling to ambient temperature, the treated waste was filtered through a 0.45 um dead-end filter. The density of the filtrate was determined and a sample collected for analyses (MR-03). Table 2.5 listed the samples and analyses required.

Table 2.5. Samples and Their Required Analyses

\begin{tabular}{|l|c|c|c|c|}
\hline Process Variable & $\begin{array}{c}\text { Sample ID } \\
\text { Number }\end{array}$ & $\begin{array}{c}\text { Sample } \\
\text { Type }\end{array}$ & $\begin{array}{c}\text { Sample } \\
\text { Preparation }\end{array}$ & Analytes \\
\hline Archived AN-107 & MR-01 & Slurry & acid digest & Sr-90, Am-241, Na \\
\hline Archived AN-107 & MR-02 & Slurry & $\begin{array}{c}0.45 \text { um filter, } \\
\text { acid digest }\end{array}$ & Sr-90, Am-241, Na \\
\hline Treated AN-107 & MR-03 & Filtrate & acid digest & Sr-90, Am-241, Na \\
\hline
\end{tabular}




\subsection{Chemical Analyses}

All of the chemical analyses were conducted at Battelle. BNFL designated the analytes of interest and minimum reportable quantity in the test specification (see test instructions in appendix). Because the archived AN-107 sample had most of the radioactive cesium removed, Am-241 concentration could be determined directly by gamma energy analysis along with the $\mathrm{Eu}$ isotopes 154 and 155 . Relatively high levels of Cs-137 raise the gamma background level in the detector due to Compton scattering, thereby making it difficult to detect other, lower-level gamma emitters, especially those having gamma energies below that of Cs-137. The Sr-90 concentration was determined by chemical separation followed by beta counting. Sodium concentration was determined by inductively couple plasma-atomic emission spectrometry, as well as the other metals listed in the test specification

The samples taken during tests in HLRF were transferred to the SAL for analytical sample preparation. All of the analytical results are included in Appendix C. 


\subsection{RESULTS AND DISCUSSION}

The results of the testing and analyses are discussed below for entrained solids removal, $\mathrm{Sr} / \mathrm{TRU}$ decontamination, and Sr/TRU solids removal from archived AN-107 samples.

The experimental and test conditions were defined by BNFL in Test Specification (Townson 1998, 1999) documents, change request documents, and direct communications with BNFL staff. General test plans were prepared for LAW crossflow filtration and Sr/TRU removal tests (TP-29953-004 and-013). Test instructions were prepared which detailed the specifics for conducting and documented deviations from the test specification for conducting tests with archived AN-107 waste. The test instructions were used to record the specific details of the tests, and are attached in Appendix A and B.

\subsection{Entrained Solids Removal}

The proposed pretreatment flowsheet shows entrained solids are removed from the double-shell tank wastes as a first step pretreatment. The entrained solids removal test was conducted with a caustic adjusted ( $1 \mathrm{M}$ hydroxide), archived AN-107 waste sample. The test demonstrated that the entrained solids present in this waste could not easily be removed by crossflow filtration. For entrained solids removal, the initial flux dropped in less than a minute to $0.023 \mathrm{gpm} / \mathrm{ft}^{2}$ and within 5 minutes had dropped to $0.0074 \mathrm{gpm} / \mathrm{ft}^{2}$ at 55 psi transmembrane pressure (TMP) and $12.2 \mathrm{ft} / \mathrm{s}$ crossflow velocity. To prevent further plugging of the filter, no further testing was conducted at this condition. An attempt was made to collect sufficient filtrate to backpulse (clean) the filter. Only a small quantity of material could be collected in the backpulse chamber and two short backpulses were performed. A second condition was then tested at 70 psi and $9.3 \mathrm{ft} / \mathrm{s}$ (Condition 3 of the test matrix). In this case, after $1 \mathrm{~min}$ the filtrate flux was 0.0079 $\mathrm{gpm} / \mathrm{ft}^{2}$. Testing was stopped at this point and entrained solids removal was determined to be not feasible for AN-107 waste.

The archived AN-107 sample had most of the entrained solids removed by settle/decant and deep bed filtration as part of the ion exchange column testing. No visible solids remained, yet the sample could not be easily filtered. This suggests fine particles or colloidal solids are suspended in the AN-107 sample that plug or foul the filter media. The high axial velocity of liquid across the filter surface did not help filter performance, which suggests that filter cake build up is not an issue. Entrained solids removal is expected to be worse for AN-107 diluted feed because it has approximately $1 \%$ settled solids and has not been diluted and used for ion exchange testing.

The archived AN-107 sample was drained from the CUF and Sr/TRU precipitation test was conducted on the sample containing the entrained solids. The samples collected during the attempted filtration of the entrained solids were not analyzed. 


\section{$3.2 \mathrm{Sr} / \mathrm{TRU}$ Decontamination}

$\mathrm{Sr} / \mathrm{TRU}$ removal tests were conducted at two different target concentrations of caustic and reagent addition. To prepare the waste for the filtration tests using the CUF, chemicals were added to give a calculated final concentration of $1 \mathrm{M}$ hydroxide, $0.075 \mathrm{M} \mathrm{Sr}$, and $0.05 \mathrm{M}$ permanganate. Later as part of the sulfate removal scoping tests, $\mathrm{Sr}$ /TRU removal was determined for lower concentrations of added chemicals, $0.8 \mathrm{M}$ hydroxide, $0.05 \mathrm{M} \mathrm{Sr}$, and $0.03 \mathrm{M}$ permanganate. The results from these two experiments will determine the potential to minimize the addition of chemicals and the resulting amount of $\mathrm{Sr} / \mathrm{TRU}$ removal solids for disposal as high activity waste.

Multiple samples were taken during the Sr/TRU removal tests and analyzed to determine the change in waste composition upon treatment. Samples were taken after various stages of treatment and filtration. The radionuclide composition of the treated samples was compared with the initial composition to determine the extent of decontamination. The initial waste composition is the composition after caustic addition and any dilution that may have occurred. The Decontamination Factor (DF) is defined as the concentration of the component in the initial waste divided by the concentration after treatment, corrected by the amount of dilution that occurred:

$$
D F=[A]_{i} /([A] * M D)
$$

where $[A]_{i}$ is the concentration of component $A$ per mass in the initial sample, [A] is the concentration of component $A$ per mass in the treated sample, and $M D$ is the mass dilution, final mass of treated solution divided by the initial mass of solution. The final mass is determined by summing up the mass of initial waste and all dilution, adjustments, and/or reagent additions.

The archived AN-107 sample from the entrained solids test was used for the higher reagent concentration, $\mathrm{Sr} / \mathrm{TRU}$ removal test. At ambient hot-cell temperature, approximately $75 \mathrm{~mL}$ of $1 \mathrm{MSr}\left(\mathrm{NO}_{3}\right)_{2}$ and $50 \mathrm{~mL}$ of $1 \mathrm{M} \mathrm{NaMnO}_{4}$ were added to $882 \mathrm{~mL}$ of the caustic adjusted (1M) waste drained from the CUF. The precipitated waste was digested at $50^{\circ} \mathrm{C}$ for 4 hours. Table 3.1 lists the samples analyzed, mass dilution to be used for calculating DFs, and description of the sample.

Table 3.1. Samples and Mass Dilution for Calculating Decontamination Factors

\begin{tabular}{|c|c|l|}
\hline Sample ID & Mass Dilution & \multicolumn{1}{c|}{ Sample Description } \\
\hline MN-21 & - & initial waste, filtered and acid digested \\
\hline MN-22 & 1.1247 & treated waste before CUF tests, filtered and acid digested \\
\hline MN-23 & 1.1247 & CUF filtrate during Condition 1, acid digested \\
\hline MN-31 & 1.1247 & CUF filtrate during Condition 6, acid digested \\
\hline MN-32 & 1.1247 & Composite CUF filtrate, Conditions 1-6, acid digested \\
\hline
\end{tabular}


The strontium, americium, and europium supernatant decontamination factors for samples MN22 through $\mathrm{MN}-32$ are shown in Table 3.2. All samples had very high decontamination for $\mathrm{Sr}$ and TRU components, greatly exceeding the requirements for ILAW. No decontamination of Co-60 or Cs-137 was observed. The concentration of Sr-90 and major TRU components for CUF composite filtrate, $\mathrm{MN}-32$, is given to represent the expected $\mathrm{Sr} / \mathrm{TRU}$ concentration of treated AN-107 waste.

Table 3.2. Strontium, Am, and Eu Decontamination Factors for Samples MN-22 to MN-32 and the Composition of Composite CUF Filtrate (MN-32)

\begin{tabular}{|l|c|c|c|c|c|c|}
\hline & MN-22 & MN-23 & MN-31 & MN-32 & $\begin{array}{c}\text { Target } \\
\text { DF }\end{array}$ & $\begin{array}{c}\text { MN-32 } \\
(\mu \mathrm{Ci} / g)\end{array}$ \\
\hline Sr-90 & 23 & 20 & 21 & 19 & 10 & 1.82 \\
\hline Am-241 & 32 & 20 & 19 & 17 & 5 & $8.9 \mathrm{E}-3$ \\
\hline Eu-154 & 15 & 11 & 9 & 9 & $*$ & $2.3 \mathrm{E}-2$ \\
\hline Eu-155 & 15 & 11 & 8 & 9 & $*$ & $1.7 \mathrm{E}-2$ \\
\hline
\end{tabular}

* reduces activity of ILAW

A separate sample of archived AN-107 was used for the lower reagent concentration, $\mathrm{Sr} / \mathrm{TRU}$ removal test. The caustic level was adjusted by adding approximately $48 \mathrm{~mL}$ of $19 \mathrm{M} \mathrm{NaOH}$ to 1-L of archived AN-107. The waste was well mixed and two samples removed. At ambient hotcell temperature, approximately $57 \mathrm{~mL}$ of $1 \mathrm{MSr}\left(\mathrm{NO}_{3}\right)_{2}$ and $34 \mathrm{~mL}$ of $1 \mathrm{M} \mathrm{NaMnO}_{4}$ were added to $1 \mathrm{~L}$ of the caustic adjusted $(0.8 \mathrm{M})$ waste. The precipitated waste was digested at $50^{\circ} \mathrm{C}$ for 4 hours. After cooling, the waste was filtered through a 0.45 um deadend filter and a sample of the filtrate collected. Table 3.3 lists the samples analyzed, mass dilution to be used for calculating DFs, and description of the sample.

Table 3.3. Samples and Mass Dilution for Calculating Decontamination Factors

\begin{tabular}{|c|c|l|}
\hline Sample ID & Mass Dilution & \multicolumn{1}{c|}{ Sample Description } \\
\hline MR-01 & - & initial waste, acid digested (entrained solids present) \\
\hline MR-02 & - & initial waste, filtered and acid digested \\
\hline MR-03 & 1.0929 & treated waste filtrate, acid digested \\
\hline
\end{tabular}

Table 3.4 shows the DFs calculated based on the initial total sample (including entrained solids) and based on initial supernatant only for analyzed radioactive elements. Entrained solids removal contributed little to the DF. For Am-241, entrained solids account for approximately $10 \%$ of the total. The DFs were very high and consistent with the earlier $\mathrm{Sr} / \mathrm{TRU}$ removal test at higher concentration. These results suggest that the decontamination requirements for $\mathrm{Sr}$ and TRU can be met with reduced reagent concentrations. 
Table 3.4. Radioactive Element Decontamination Factors and Composition of Filtrate (MR-03)

\begin{tabular}{|l|c|c|c|c|}
\hline & $\begin{array}{c}\text { Total Sample } \\
\text { DF }\end{array}$ & $\begin{array}{c}\text { Supernatant } \\
\text { DF }\end{array}$ & $\begin{array}{c}\text { Target } \\
\text { DF }\end{array}$ & $\begin{array}{c}\text { Composition of } \\
\text { Filtrate (uCi/g) }\end{array}$ \\
\hline Sr-90 & 31 & 37 & 10 & 1.0 \\
\hline Am-241 & 18 & 10 & 5 & $1.3 \mathrm{E}-2$ \\
\hline Eu-154 & 12 & 7 & $*$ & $2.2 \mathrm{E}-2$ \\
\hline Eu-155 & 12 & 7 & $*$ & $1.5 \mathrm{E}-2$ \\
\hline Total Beta & 38 & 35 & - & 2.1 \\
\hline
\end{tabular}

* reduces activity of ILAW

\subsection{Change in Chemical Composition}

The $\mathrm{Sr} / \mathrm{TRU}$ precipitation and solids removal steps changed the chemical composition of the waste samples, i.e. solids and supernatant. Table 3.5 shows the compositional change of the major ICP elements and density for the various samples. The most interesting changes are for $\mathrm{Fe}$ and $\mathrm{Mn}$. Both are relatively high in the initial waste (MN-21). On treatment, Fe removal was very high, and most likely correlated directly with the high removal of Am and Eu isotopes. Manganese also decreased significantly, which suggests that soluble $\mathrm{Mn}$, likely $\mathrm{Mn}(\mathrm{II})$, is oxidized to insoluble $\mathrm{Mn}$ (IV) by reaction with $\mathrm{Mn}(\mathrm{VII})$. Calcium is precipitated on treatment while the $\mathrm{Sr}$ concentration increased because the original solution was below the saturation level for $\mathrm{Sr}$, and a fraction of the added $\mathrm{Sr}$ remained soluble. The free hydroxide, determined by titration, decreased very little on precipitation with $\mathrm{Sr}$ and permanganate, $0.03 \mathrm{M}$ after correction for dilution. This is in contrast to the earlier proposed Fe precipitation for TRU removal, which consumed 3 times the added Fe concentration of hydroxide $(3 * 0.075=0.225)$.

Sample MN-28 is the composition of the precipitated slurry, combined supernatant and precipitated solids. The solids were not analyzed, but comparison of the composition of the slurry to the initial composition and filtrates provides an indication of the solids composition. The solids contain primarily $\mathrm{Sr}$ and $\mathrm{Mn}$ as expected with lower amounts of $\mathrm{Fe}$ and $\mathrm{Ca}$. Comparing the $\mathrm{Fe}$ concentration in the initial waste and slurry suggests entrained solids contain significant $\mathrm{Fe}$. 
Table 3.5. Concentration of Major ICP Metals in Samples MN-21 to MN-32 and Sample Density (data not corrected for sample dilution from added reagents)

\begin{tabular}{|l|c|c|c|c|c|c|}
\hline & $\begin{array}{c}\text { MN-21 } \\
(\mathrm{ug} / \mathrm{g})\end{array}$ & $\begin{array}{c}\text { MN-22 } \\
\text { (ug/g) }\end{array}$ & $\begin{array}{c}\text { MN-23 } \\
(\mathrm{ug} / \mathrm{g})\end{array}$ & $\begin{array}{c}\mathrm{MN}-28 \\
\text { (ug/g) }\end{array}$ & $\begin{array}{c}\text { MN-31 } \\
\text { (ug/g) }\end{array}$ & $\begin{array}{c}\text { MN-32 } \\
\text { (ug/g) }\end{array}$ \\
\hline $\mathrm{Ca}$ & 227 & 128 & 130 & 220 & 129 & 129 \\
\hline $\mathrm{Fe}$ & 445 & 4.36 & 8 & 687 & 7.56 & 5.82 \\
\hline $\mathrm{Mn}$ & 44.1 & 3.785 & 1.13 & 2810 & 0.48 & 0.5 \\
\hline $\mathrm{Sr}$ & 1.14 & 112 & 115 & 4770 & 171 & 159 \\
\hline $\mathrm{Na}$ & 104000 & 87900 & 84600 & 85200 & 84200 & 86200 \\
\hline & $\mathrm{M}$ & $\mathrm{M}$ & $\mathrm{M}$ & $\mathrm{M}$ & $\mathrm{M}$ & $\mathrm{M}$ \\
\hline $\mathrm{Na}$ & 5.68 & 4.69 & 4.49 & 4.60 & 4.47 & 4.58 \\
\hline $\mathrm{OH}^{-}$ & 0.87 & 0.74 & - & - & - & - \\
\hline & $\mathrm{g} / \mathrm{mL}$ & $\mathrm{g} / \mathrm{mL}$ & $\mathrm{g} / \mathrm{mL}$ & $\mathrm{g} / \mathrm{mL}$ & $\mathrm{g} / \mathrm{mL}$ & $\mathrm{g} / \mathrm{mL}$ \\
\hline density & 1.26 & 1.23 & 1.22 & 1.24 & 1.22 & 1.22 \\
\hline
\end{tabular}

The lower reagent concentration test included ICP data for initial waste with and without entrained solids, and for the filtrate. The concentration of the major ICP elements for these three samples in given in Table 3.6. The most significant difference between the data from the two different concentrations of added reagents is the higher soluble $\mathrm{Mn}$ in sample filtrate from the lower treatment level. The reason for this is not understood.

The composition of the entrained solids can be estimated by comparing the composition of MR-01, initial sample with entrained solids, and MR-02, initial sample filtered before analysis. The solids are rich in $\mathrm{Fe}$ and $\mathrm{Mn}$. This is consistent with the data from Lumetta and Hoopes (1999) on washing/leaching of AN-107 solids.

Table 3.6. Concentration of Major ICP Metals in Samples MR-01 to MR-03 (data not corrected for sample dilution from added reagents)

\begin{tabular}{|l|c|c|c|}
\hline & $\begin{array}{c}\text { MR-01 } \\
\text { (ug/g) }\end{array}$ & $\begin{array}{c}\text { MR-02 } \\
(\text { ug/g) }\end{array}$ & $\begin{array}{c}\text { MR-03 } \\
(\text { ug/g) }\end{array}$ \\
\hline $\mathrm{Ca}$ & 246 & 254 & 144 \\
\hline $\mathrm{Cr}$ & 71.4 & 50.4 & 31.8 \\
\hline $\mathrm{Fe}$ & 687 & 219 & 11.7 \\
\hline $\mathrm{Mn}$ & 139 & 24.6 & 27.4 \\
\hline $\mathrm{Sr}$ & 1.2 & 1.2 & 109 \\
\hline $\mathrm{Na}$ & 92700 & 96000 & 104000 \\
\hline & $(\mathrm{g} / \mathrm{mL})$ & $(\mathrm{g} / \mathrm{mL})$ & $(\mathrm{g} / \mathrm{mL})$ \\
\hline density & 1.26 & 1.26 & 1.26 \\
\hline
\end{tabular}




\subsection{Sr/TRU Solids Removal}

Removal of entrained solids from the archived AN-107 sample with crossflow filtration was not practical so the $\mathrm{Sr} / \mathrm{TRU}$ precipitation was conducted with entrained solids present. The resulting slurry, containing both entrained solids and $\mathrm{Sr} / \mathrm{TRU}$ precipitate, was transferred to the CUF and filtration tests conducted. Figure 3.1 shows filtrate flux data for entrained solids removal alone and for $\mathrm{Sr} / \mathrm{TRU}$ precipitate/entrained solids removal from archived $\mathrm{AN}-107$ at target conditions of $55 \mathrm{psi}$ TMP and $12.2 \mathrm{ft} / \mathrm{s}$ crossflow velocity (Condition 1). The $\mathrm{Sr} / \mathrm{TRU}$ removal process, precipitation with added $\mathrm{Sr}\left(\mathrm{NO}_{3}\right)_{2}$ and $\mathrm{NaMnO}_{4}$, dramatically improved the filtrate flux rate for the archive $\mathrm{AN}-107$ material. The filtrate flux was an order of magnitude higher for the treated waste, $0.11 \mathrm{gpm} / \mathrm{ft}^{2}$ averaged over $30-60 \mathrm{~min}$ of testing.

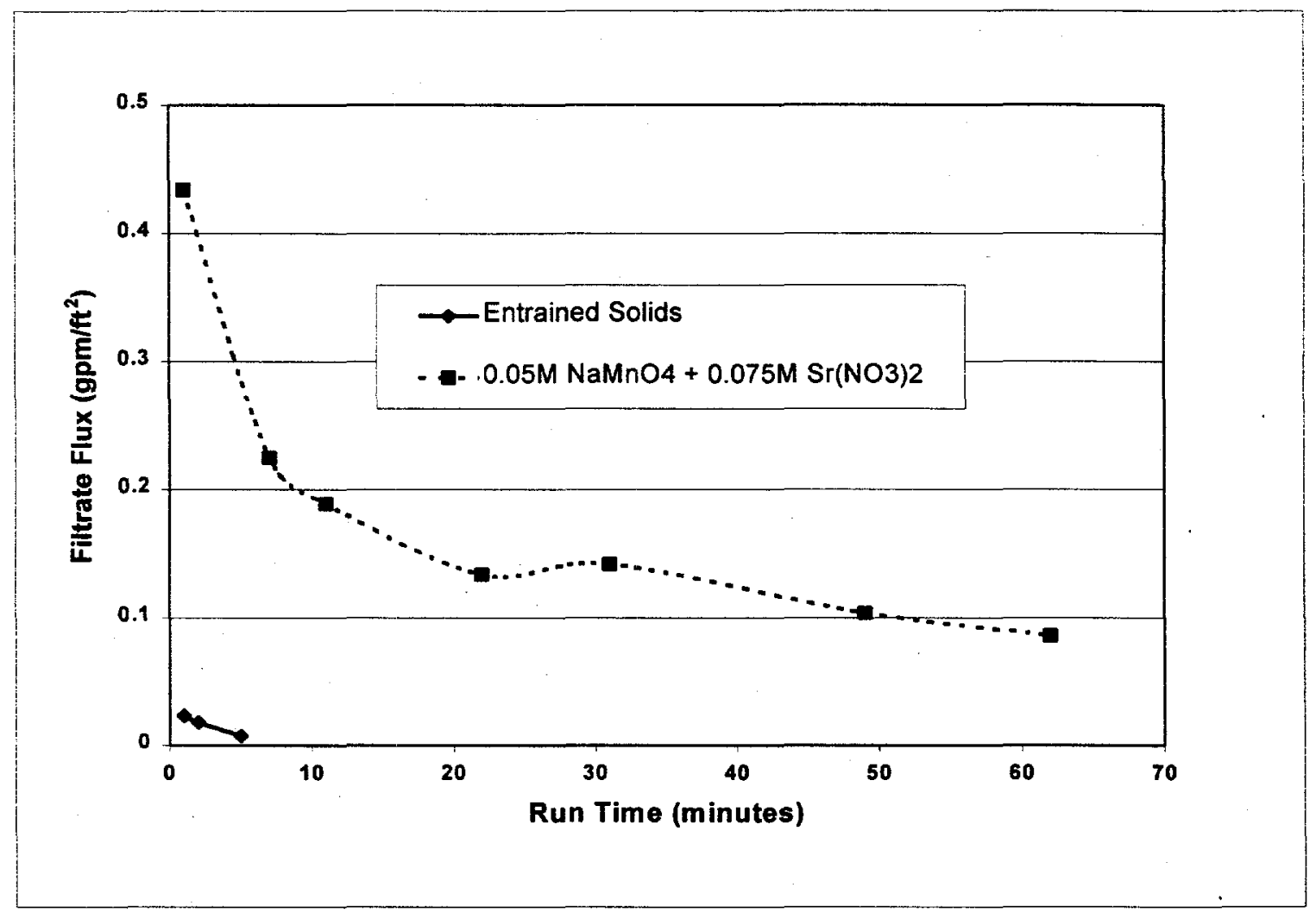

Figure 3.1. Comparison of the Filtrate Flux for Entrained Solids and Sr/TRU Precipitate/Entrained Solids Removal from Archived AN-107 Waste at Target Conditions of 55 psi TMP and $12.2 \mathrm{ft} / \mathrm{s}$ Crossflow Velocity

Based on these results, it appears that the $\mathrm{Sr} / \mathrm{TRU}$ precipitate addition acts as a filter aid. This is further illustrated when the particle size distribution measurements are compared. The entrained solids and $\mathrm{Sr}$ /TRU precipitate samples were analyzed using the Microtrac UPA. The particles size distribution of the small particles measured with this instrument are shown in Figure 3.2. Results indicate that the bulk of the entrained solids are one micron and less, while the $\mathrm{Sr} / \mathrm{TRU}$ precipitate particles are generally larger, beyond the range of the UPA instrument. 


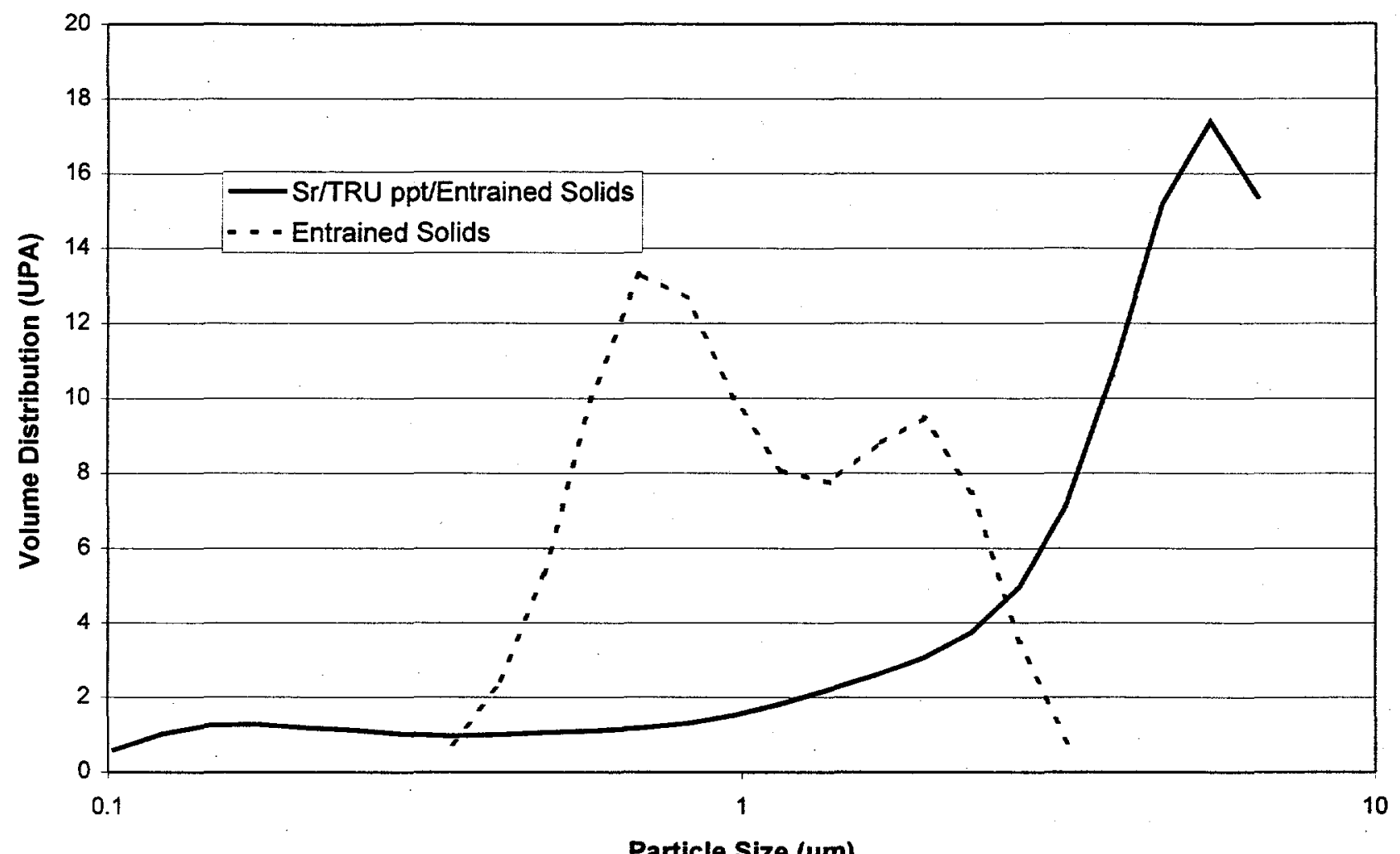

Figure 3.2. Volume-Weighted Particle Size Distribution Comparison Between Archive AN-107 Entrained Solids and Sr/TRU Precipitate

It is believed that during subsequent conditions (2-6), the shearing of the pump breaks apart the precipitated flocs resulting in smaller particles that reduce the filtrate flux. The results averaged between 20 and 60 minutes of testing for each condition are shown below in Figure 3.3. The results show a steady decline in filtrate flux over time. In fact, over conditions 2 through 5 , it is nearly a linear decrease, in spite of the changes in transmembrane pressure and axial velocity. The pressure and velocity at the initial condition was repeated for the final condition. During the 8.5 hours of run time, the filtrate flux dropped by $55 \%$.

The transmembrane pressure and axial velocity effects can also be seen in this data set. The transmembrane pressure appears to have little effect on the filtrate flux over the range from 38 to $70 \mathrm{psi}$. In fact, there is a decrease in filtrate flux between condition 2 (at 38 psid) and condition 3 (at $70 \mathrm{psid}$ ). The axial velocity, on the other hand, does appear to improve filtrate flux as evidenced by the increase in filtrate flux between condition 5 and condition 6 . The reduction in filtrate flux for condition 3 compared to condition 2 may be largely due to the decreased axial velocity, not the increase in pressure. 


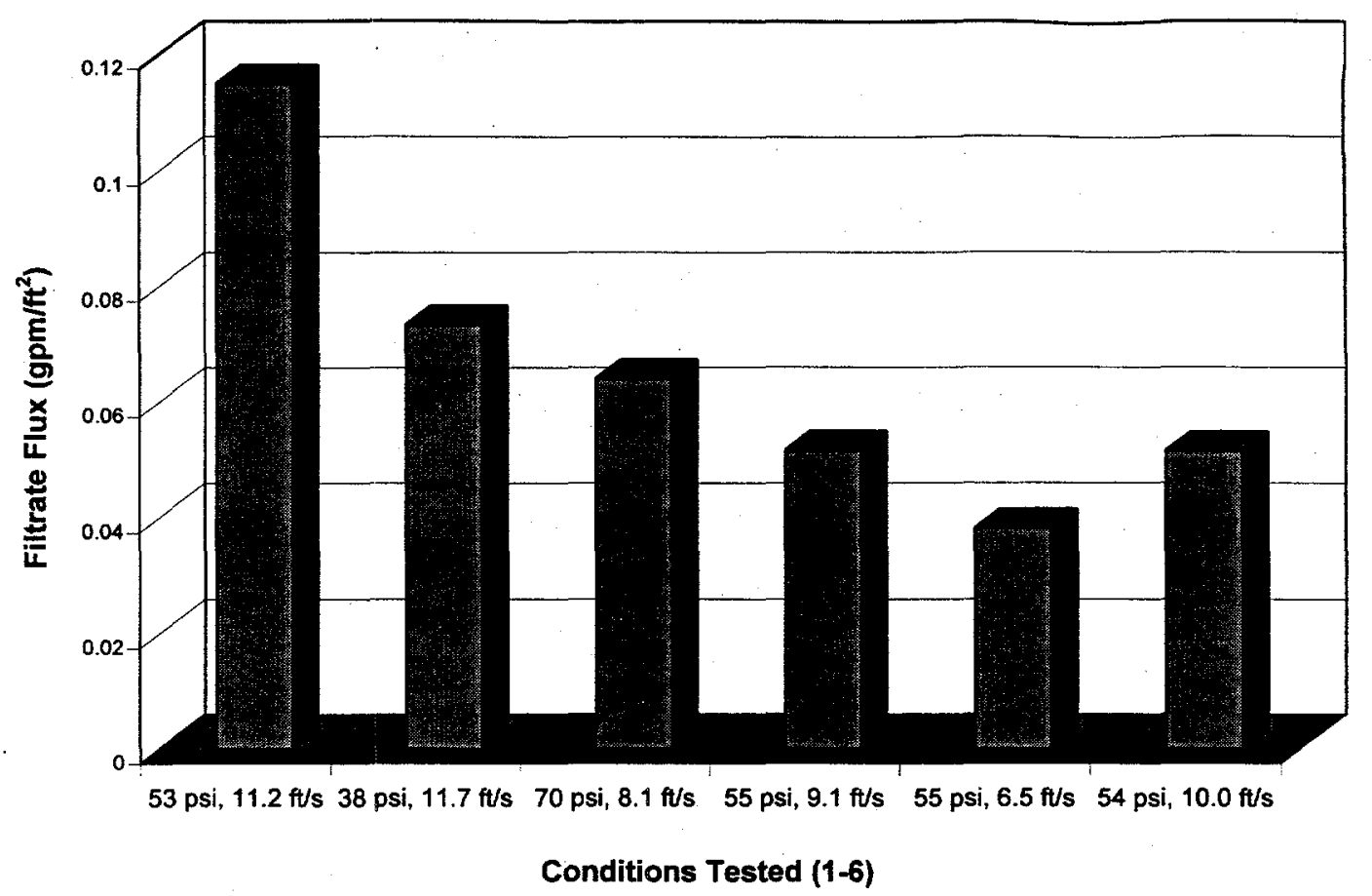

Figure 3.3. Average Filtrate Flux for Conditions Tested With the Archived AN-107 Sr/TRU Precipitate

In the full-scale process, the material will not continuously run through the pump to the extent seen in these liter-scale tests and thus filtrate fluxes may remain high at the other conditions. Thus, the time effect observed here may not significantly impact design. To remove the time dependency, statistical analysis is required. Non-linear regression was used to develop an equation describing flux as a function of time, axial velocity and transmembrane pressure. By minimizing the residual error, the following equation was developed:

where flux is the filtrate flux in $\mathrm{gpm} / \mathrm{ft}^{2}$, time is hours from the start testing, velocity is the crossflow velocity in $\mathrm{ft} / \mathrm{s}$ and pressure is the transmembrane pressure in psi. The time dependence is assumed to be exponential decay while the velocity and pressure dependence are assumed to be linear. Using this equation, it can be seen that both pressure and velocity increases result in improved filtrate flux. Crossflow velocity has a higher impact on filtrate flux over the conditions studied. Total filtration time is the dominant factor in predicting filtrate flux.

The cause of this reduction in filtrate flux over time may be the result of filter fouling. After cleaning the filter with DI water following the run, the filtrate flux was still significantly less than its original value. This is evidence of filter fouling. Furthermore, there is evidence that the particle size may have been reduced during the course of the run. These fines may become 
lodged inside the filter and result in the reduction of filtrate flux. Particle size distribution was performed using a Microtrac UPA with the Sr/TRU precipitate taken after CUF filtration. These samples were analyzed with and without sonication. By sonicating the sample, the effects of shear, similar to that seen in the pump can be evaluated. A plot of the sample PSD before and after sonication is shown in Figure 3.4. The plot shows a reduction in particle size on sonication over the range evaluated. Particles below 0.1 um particle size were found.

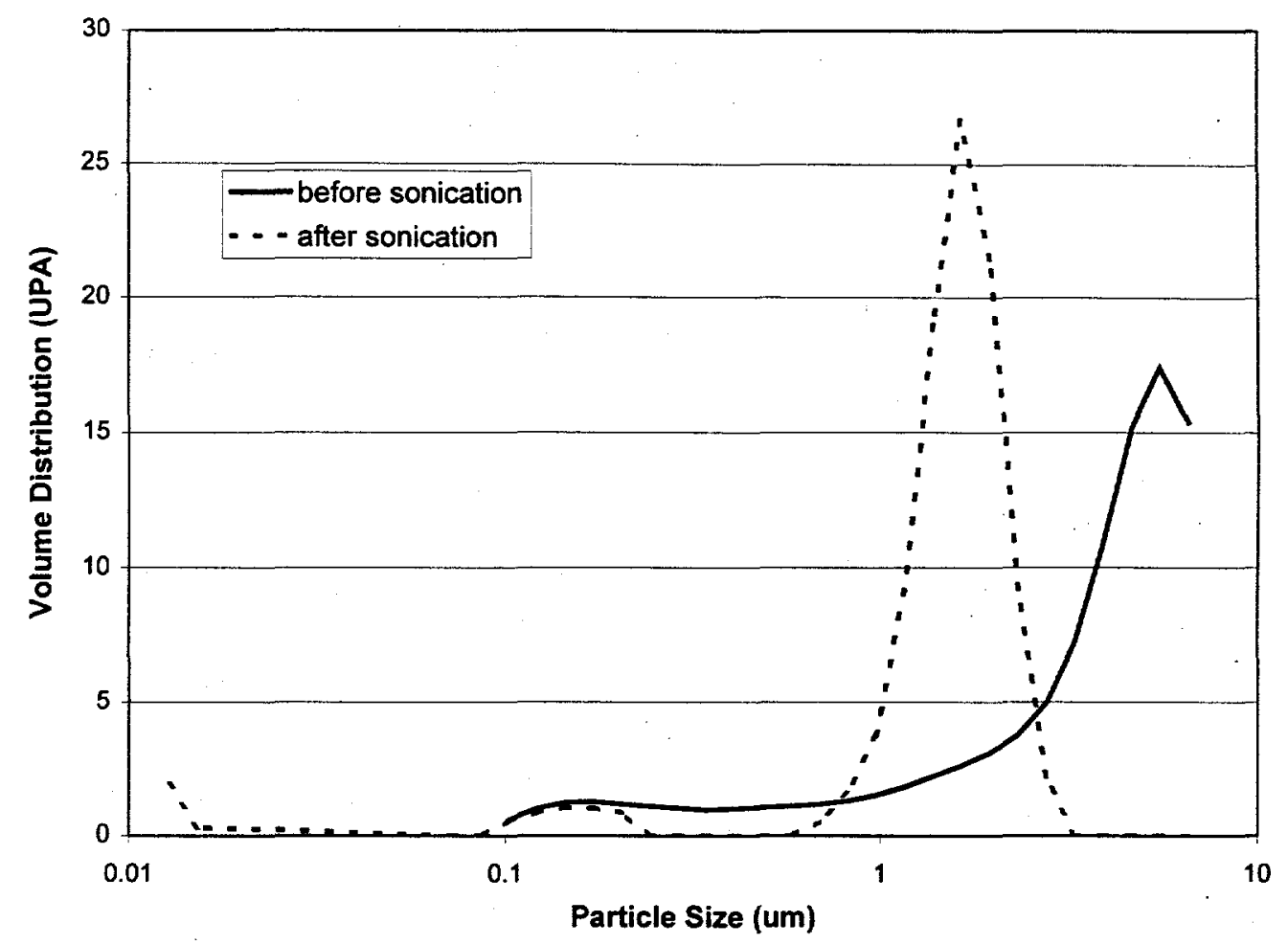

Figure 3.4. Particle Size Distribution Comparison of Archive AN-107 Sr/TRU Precipitate With and Without Sonication 


\subsection{CONCLUSIONS AND RECOMMENDATIONS}

Archived AN-107 waste was used to evaluate entrained solids removal, Sr/TRU decontamination of supernatant, and Sr/TRU solids removal. Even though most of the entrained solids had been previously removed from the archived sample, the residual entrained solids rapidly fouled the filter element resulting in very poor filter performance. An attempt to run at higher pressure resulted in more fouling, and reduced filter performance. Filtration efforts to remove entrained solids were abandoned and the waste was treated for $\mathrm{Sr}$ /TRU removal with the entrained solids present.

The new processing scheme for $\mathrm{Sr} / \mathrm{TRU}$ removal involving precipitation by added strontium and permanganate worked well. The decontamination factors for $\mathrm{Sr}$ and TRU components were significantly greater that the ILAW DF requirements for higher reagent concentrations of $1 \mathrm{M}$ hydroxide, $0.075 \mathrm{M} \mathrm{Sr}$, and $0.05 \mathrm{M}$ permanganate and lower reagent concentrations of $0.8 \mathrm{M}$ hydroxide, $0.05 \mathrm{M} \mathrm{Sr}$, and $0.03 \mathrm{M}$ permanganate. These results support the use of lower concentration of reagent additions in future tests. Optimization studies should be conducted to examine the reduction in added hydroxide from $1 \mathrm{M}$ to $0.5 \mathrm{M}$, reduction of $\mathrm{Sr}$ from $0.075 \mathrm{M}$ to $0.05 \mathrm{M}$, and reduction in permanganate from $0.05 \mathrm{M}$ to $0.03 \mathrm{M}$ and the impact this reduction has on filtration performance with new samples from Tank AN-107.

The combined entrained solids and $\mathrm{Sr} / \mathrm{TRU}$ precipitate were successfully filtered in the single element, crossflow filtration unit. The filtrate flux was high, $>0.1 \mathrm{gpm} / \mathrm{ft}^{2}$, at the initial test conditions of $53 \mathrm{psi}$ and $11.2 \mathrm{ft} / \mathrm{s}$ for the treated archived AN-107 sample. The filter flux rate dropped significantly with time as testing progressed and appears to be a result of shearing the agglomerated solids and fouling of the filter element by the resulting fine particles. The relatively low clean water flux rates obtained at the end of the test also indicate filter fouling. Chemical cleaning was required to restore clean water flux rates to pre-test levels. The filter performance as a function of wt\% solids could not be determined in this study because the treated waste volume was close to the minimum CUF volume and no dewatering could occur. Additional filtration tests need to be conducted to determine the filtrate flux as a function of $w t \%$ solids. Solids washing in the CUF also needs to be conducted to determine filtrate flux rate as a function of solids loading during washing. 


\subsection{REFERENCES}

Brooks, K. P., P. R. Bredt, G. R. Golcar, S. A. Hartley, M. W. Urie, J. M. Tingey, K. G. Rappe, and L.K. Jagoda. 1999. Ultrafiltration and Characterization of $A W-101$ Supernatant and Entrained Solids, PNWD-3000, Battelle, Richland, Washington.

Hallen, R. T., K. P. Brooks, and L. K. Jagoda. 2000. Development of an Altermative Treatment Scheme for Sr/TRU Removal: Permanganate Treatment of AN-107 Waste, PNWD-3047, Battelle, Richland, Washington.

Hendrickson, D.W. 1997. Hanford Complexant Concentrate Cesium Removal Using Crystalline Silicotitanate, SESC-EN-RPT-005, Rev. 0, SGN Eurisys Services Corporation Richland, Washington.

Krot, N. N., V. Shilov, A. Bressonov, N. Budantseva, I. Charushnikova, V. Perminov, and L. N. Astafurova. 1996. Investigation on the Coprecipitation of Elements from Alkaline Solutions by the Method of Appearing Reagents, WHC-EP-0898, Westinghouse Hanford Company, Richland, Washington.

Lumetta, G.J. and F.V. Hoopes. 1999. Washing of the AN-107 Entrained Solids, PNWD-2469, Battelle Pacific Northwest Division, Richland, Washington.

Orth, R. J., A. H. Zacher, A. J. Schmidt, M. R. Elmore, K. R. Elliott, G. G. Neuenschwander, and S. R. Gano. 1995. Removal of Strontium and Transuranics from Hanford Tank Waste via Addition of Metal Cations and Chemical Oxidant - FY 1995 Test Results, PNL-10766, Pacific Northwest Laboratory, Richland Washington.

Rapko, B.M., G.J. Lumetta, and M.J. Wagner. 1996. Oxidative Dissolution of Chromium from Hanford Tank Sludges Under Alkaline Conditions, PNNL-11233, Pacific Northwest National Laboratory, Richland, Washington

Rapko, B.M. 1998. Oxidative Alkaline Dissolution of Chromium from Hanford Tank Sludges Resultsof FY 98 Studies, PNNL-11908, Pacific Northwest National Laboratory, Richland, Washington.

River Protection Project Waste Treatment Plant (RPP-WTP) (formerly TWRS) Privatization Contract (mod. 14). 2000. DE-AC27-RL13308. U.S. Department of Energy, Richland, Washington.

Schroeder, N. C., J. G. Bernard, D. L. Clark, J. R. Ball, K. R. Ashley, A. P. Truong, and D. L. Blanchard. 1998. Fundamental Chemistry, Characterization, and Separation of Technetium Complexes in Hanford Wastes, Environmental Management Science Program Workshop, July 27-30, Chicago, Illinois.

SRTC 1997a, Hanford Envelope Archive C Tank Waste Precipitation Study, March 20, 1997, SRTC-BNFL-004, revision 0, Savannah River Technology Center, Aiken, South Carolina.

SRTC 1997b, Hanford Simulant Tank Waste Precipitation Study, July 8, 1997, SRTC-BNFL-006, revision 1, Savannah River Technology Center, Aiken, South Carolina. 
SRTC 1997c, Hanford Envelope C Tank Waste Precipitation Study, August 13, 1997, SRTC-BNFL-005, revision 2, Savannah River Technology Center, Aiken, South Carolina.

SRTC 1997d, Hanford Envelope C Tank Waste Sr/TRU Precipitation Demonstration, November 18, 1997, SRTC-BNFL-024, revision O, Savannah River Technology Center, Aiken, South Carolina.

Townson, Paul S., 1998, Sr/TRU Precipitation and Ultrafiltration Test

Specification TSP.W375-99-00004 Rev. 0, December 15, 1998, BNFL Inc., Richland, Washington. 


\title{
Appendix A: Test Instruction-041, Data Sheets, and Log Book Entries
}

Scoping Studies: Entrained Solids Removal, Permanganate Treatment for

Sr/TRU Removal, and Precipitate Removal from Archived AN-107

\author{
Data Sheets
}

Log Book Entries 


\subsection{Applicability}

This test instruction is to be used to perform studies on entrained solids removal, permanganate treatment for Sr/TRU removal and precipitate solids removal from archived AN-107 waste that has been previously treated by cesium ion exchange resin. The entrained solids and precipitate will be removed using the Cell Unit Filter (CUF) in the HLRF A-cell from approximately 1-L of $\mathrm{AN}-107$ waste (C3E5, C3E4 and/or C3E6). The permanganate treatment is to be conducted after the entrained solids removal and before precipitate removal.

\subsection{Supporting Documents}

This test instruction is not a stand-alone document. It will be used in conjunction with PNNL Operating Procedure BNFL-TP-29953-020 which contains the necessary procedural information for the safe operation of the CUF. It is also linked to PNNL Test Plan \#s BNFLTP-29953-004 and -013 which contains an overall description of the project, ES\&H compliance, emergency response, and the hazards assessment and mitigation. Scoping tests on the permanganate treatment of $\mathrm{AN}-107$ (cesium removed) is described in detail in test instruction, TP-29953-037.

\subsection{Responsible Staff}

The staff responsible for executing this test plan are as follows.

- Task Managers - Kriston Brooks and Rich Hallen

- SFO Manager - Randy Thornhill

- Test Scientists/Engineers - Kriston Brooks, Ken Rappe, Lynette Jagoda, Sam Bryan, and Rich Hallen

- Hot Cell Technician -Mac Zumhoff, Don Rinehart, and Ralph Lettau

- Radiological Control Technician

\subsection{Materials, Equipment, Supplies and Reagents Needed}

\subsection{Materials Required}

r1. Twenty two $20 \mathrm{~mL}$ glass scintillation vials for filtrate and slurry samples, pre-labeled on top and side as follows: $M N-21$ through MN-30 and CUF-AAN107-01 through CUF-AAN107-10, and Tc IX -01 and Tc IX-02.

$\checkmark$ 2. Three 1 liter polyethylene bottles. They should be labeled as follows: "MNO4 CUF Slurry," "CUF Archive AN-107 First Rinse" and "MNO4 CUF First Rinse." The bottle labeled "MNO4 CUF Slurry" should be marked with graduation lines at $100 \mathrm{~mL}$ intervals up to $1000 \mathrm{~mL}$.

3. Two 10 liter containers, one labeled for the alkaline rinses and the other labeled for the acidic rinses.

4. Containers for draining from the bottom of the pump and from the sample valve.

$\checkmark$ 5. 12 liters of 0.2 micron filtered DI water for determining clean water flux and for rinsing the CUF

\subsection{Equipment}

$\because$ 1. 4000 gram balance

2. $\mathrm{pH}$ paper 
$\sqrt{3}$. Hand held camera. To be used to read filtrate flowmeter.

$\checkmark 4$. Stopwatch

$\checkmark 5$. Calculator

6. CUF Ultrafiltration system with $100 \mathrm{~mL}$ plug in place using $0.1 \mathrm{micron}$ Mott-L filter and new pump rotor

7. $1000 \mathrm{~W}$ Chiller

8. 2-L flask

9. hot-stir plate (Ko-cell)

10. big stir bar

11. $2 \mathrm{~mL}$ pipet

\subsection{Reagents Needed}

1. 2 liters of $1 \mathrm{M} \mathrm{HNO}_{3}+0.1-0.2 \mathrm{M}$ Citric Acid

2. 1 liter of $5 \mathrm{ppm}$ hypochlorite solution $(\mathrm{pH}>7)$

$\sqrt{3} .50 \mathrm{~mL}$ of 1.0M NaMnO4

4. $75 \mathrm{~mL}$ of 1.0M Sr(NO3)2

V5. 1 liter of Archive $\mathrm{AN}-107$ that has been adjusted to $1 \mathrm{MOH}^{-}$

\subsection{Other Supplies}

: 1. Workplace Copy of Operating Procedure BNFL-TP-29953-020

$\checkmark 2$. Extra Copies of Data Sheets 1,2, and 3

$\checkmark$ 3. Laboratory Record Book

$\checkmark$ 4. DAS disk for recording data

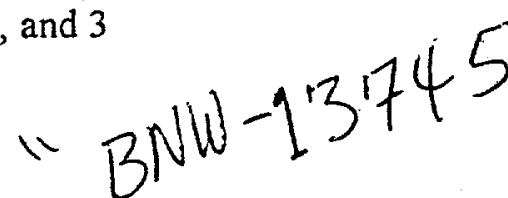

\subsection{Test Instructions for CUF Operation and Permanganate Treatment}

The laboratory record book (LRB) shall be used to record other testing information as required by this procedure and all test conditions not stated by this procedure.

Cross-contamination between samples and contamination of samples from outside sources must be minimized at each step. Use new tools and bottles for each sample as much as possible. Those tools that are reused should be washed and rinsed prior to reuse.

Keep all test materials in sealed containers as much as possible to prevent them from drying.

\subsection{Pre-start for Scoping Studies}

5.1.1 Inventory materials, equipment, supplies, and reagents to ensure all required items are available. Assure that all materials have been modified for remote handling.

5.1.2 Do the following and initial and date when each item is completed.

Review PNNL Operating Procedure BNFL-TP-29953-020. 
Review the work instructions in BNFL-TP-29953-041.

5.1.3 Conduct the "0.0 Pre-Start" operations in BNFL-TP-29953-020. Drain the system overflow container.

5.1.4 Perform "1.0 Start-Up" operations in BNFL-TP-29953-020 with 1 liter of filtered DI water with one variation: V4 the filtrate control valve should be closed. Run CUF for 5 minutes at between 4-6 gpm. In-line pressure should be varied from using V1 from 10 to $70 \mathrm{psig}$. Ensure that there are no leaks in the system. If leaks are detected, shut down system immediately.

5.1.5 Conduct the "10.0 Draining the system" operation in BNFL-TP-29953-020.

5.1.6 Perform "1.0 Start-Up" operations in BNFL-TP-29953-020 with 1.0 liter of filtered, distilled water with one variation: V4 the filtrate control valve should be closed. Run CUF for 5 minutes at between $4-6 \mathrm{gpm}$. In-line pressure should be varied from using V1 from 10 to $70 \mathrm{psig}$.

5.1.7 Conduct the "10.0 Draining the system" operation in BNFL-TP-29953-020.

5.1.8 Perform "1.0 Start-Up" operations in BNFL-TP-29953-020 with 1.0 liter of filtered, distilled water

\subsubsection{Perform "6.0 Back pulsing" operations in BNFL-TP-29953-020.}

5.1.10 Shut off the system and conduct the "10.0 Draining the system" operation in BNFL-TP29953-020.

5.1.11 Perform "1.0 Start-Up" operations in BNFL-TP-29953-020 with 1.0 liter of filtered, distilled water.

5.1.12 Conduct the "3.0 Operation during Ultrafilter Recycle Mode" operations in BNFL-TP29953-020 using the conditions below. Filtrate flow rate should be monitored and data collected in the operating procedure. Each test should be performed for only 20 minutes and the system should be back pulsed. After each condition, the test engineer should initial and date the table below.

\begin{tabular}{|c|c|c|c|}
\hline Condition & Flowrate (gpm) & $\begin{array}{c}\text { Transmembrane } \\
\text { Pressure (psig) }\end{array}$ & $\begin{array}{c}\text { Initial and date } \\
\text { when complete }\end{array}$ \\
\hline 1 & 4.20 & 10 \\
\hline 2 & 4.20 & 20 \\
\hline 3 & 4.20 & 30 \\
\hline
\end{tabular}

5.1.13 Shut off the system and conduct the "10.0 Draining the system" operation in BNFL-TP29953-020. 


\subsection{Start-Up for CUF Operation}

5.2.1 Obtain the following information:

\section{M\&TE List:}

Pm 4 cos Balance 1:

$$
\text { Calib ID } \frac{362-06-01-054}{\text { Location } \quad \text { A-cell North }}
$$

PM430 Balance 2:

$$
\text { Calib ID } \frac{362-06-01-961}{\text { L-cell South }}
$$$$
\text { Calib Exp Date } 8 / 99
$$

Thermocouple:

\section{Calib ID}

Location

Digital Thermometer:

Calib ID

Location
Calib Exp Date

Thermocouple type

5.2.2 Record the tare and sample weight of AN-107 with storage bottles (verify/identify sample is AN-107 id\#). (This bottle should have had 40 grams of $\mathrm{NaOH}$ pellets in it to raise the hydroxide 2 in concentration to 1M.) Record the weight(s) below.

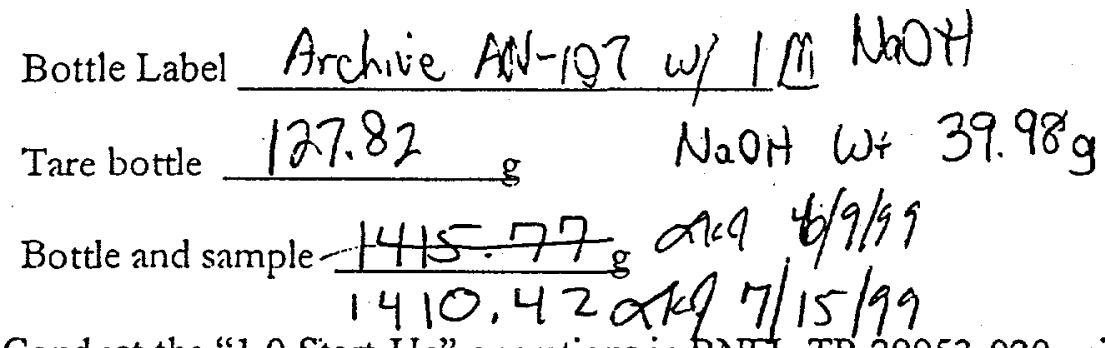

5.2.3 Conduct the "1.0 Start-Up" operations in BNFL-TP-29953-020 using AN-107. Shake the waste thoroughly before adding it to the slurry reservior. There may be some solids left the jars that cannot be transferred by shaking. If so, consult with the cognizant engineer on recovering

- these solids. DI water addition or scraping the sides with a spatula could be attempted. Record the method of recovery in the LRB.

5.2.4 Record the weight(s) of empty reaction vessel or sample bottles in the spaces provided below.

Empty bottle g 
$\therefore \quad$ ADDED
$\therefore \quad \mathrm{g}$

5.2.5 Record the level in the slurry reservoir sight glass.

Height 6 inches

\subsection{CUF Operation: Entrained Solids Removal Test with AN-107}

5.3.1 Conduct the "3.0 Operation during Ultrafilter Recycle Mode" operations in BNFL-TP29953-020 using the conditions below. Filtrate flow rate should be monitored and data collected as specified in the operating procedure. After each condition, the test engineer should initial and date the table below. If no filtrate flow occurs or the filtrate flow is less than $10 \mathrm{~mL} / \mathrm{min}$, discontinue testing and move to the next condition. After each condition, the test engineer should initial and date the table below.

NOTE: Samples of filtrate should be taken within the first 10 minutes of operation during Condition 1 and 30 minutes into each of the other 5 conditions. A slurry sample should be taken during Condition 3 . Instructions for sampling are provided below.

NOTE: Test conditions below are suggested and all conditions do not need to be run, make sure condition 1 is run for 1 hour, other conditions should be run at least 20 minutes, run as many of the conditions as time allows.

\begin{tabular}{|c|c|c|c|}
\hline Condition & Flowrate $(\mathrm{gpm})$ & $\begin{array}{c}\text { Transmembrane } \\
\text { Pressure }(\mathrm{psig})\end{array}$ & $\begin{array}{c}\text { Initial and date } \\
\text { when complete }\end{array}$ \\
\hline 1 & 4.20 & 55 & \\
\hline 2 & 4.20 & 40 & \\
\hline 3 & 4.20 & 70 & \\
\hline 4 & 3.13 & 55 & \\
\hline 5 & 5.23 & 55 & \\
\hline 6 & 4.20 & 55 & \\
\hline
\end{tabular}

5.3.2 Obtain 1 filtrate sample of at least 10 grams within the first 10 minutes of operation (during Condition 1). Record the weight and sample number in Data Sheet 3 . These will be used for chemical and radiochemical analyses.

5.3.3 Obtain filtrate samples of at least 5 grams each following "8.0 Filtrate Sampling" in BNFLTP-29953-020 and using the pre-labeled sample vials after approximately 30 minutes of operation for each condition. Record the weight and sample number in Data Sheet 3 . These will be used for chemical and radiochemical analyses.
Tare wts
CUFAAN $\overline{107}-01$ cu FAN $107-02$
Texe
17.0259
17.0349
25.580

with sampe 
5.3.4 Obtain 2 slurry samples of at least 10 grams following "7.0 Slurry Sampling" in BNFL-TP29953-020. The samples should be taken after condition 3. The first slurry sample should not be saved, but dumped back into the tank. Record the weight and sample number in Data Sheet 3.

\subsubsection{Tare weigh a prelabeled $20 \mathrm{~mL}$ sample vial.}

5.3.6 Using a pipet, transfer $2 \mathrm{~mL}$ from each of the 6 filtrate sample vials taken previously in step 5.3.3 into the sample vial. Record the weight and sample number in Data Sheet 3. This composite will be used for chemical and radiochemical analyses.

\subsubsection{Conduct the "11.0 Shutting down" operation in BNFL-TP-29953-020.}

\subsection{Entrained Solids Removal Test: Rinsing and Draining the System}

$$
\begin{aligned}
& \text { Baclc into original Bs the } \\
& \text { 5.4.1 Tare the } 1 \text { liter bottle labeled, "WOA-EUF Sturry?" } \\
& \text { Weight of bottle and lid } 1290.86 \\
& \begin{array}{l}
\text { volume calmost same } \\
\text { as pat into syskm } \\
\text { Wti luss poob. mosth solid's } \\
\text { vinued. }
\end{array}
\end{aligned}
$$

5.4.2 Conduct the "10.0 Draining the system" operation in BNFL-TP-29953-020. Collect liquid in 1 liter bottle. Make sure as much materials as possible has been collected. This materials will be used for the permanganate treatment. Weigh bottle after all liquid has been removed.

Weight of slurry, bottle and lid g

Weight of material collected g

NOTE: Sections 5.5, 5.6 and 5.7 can be completed after Step $\mathbf{5 . 4 . 2}$

5.4.3 Conduct the "9.0 Rinsing the system" operation in BNFL-TP-29953-020. The first rinse should be done with 1 liter of distiter. This liquid should be collected and saved in the container labeled "CUF Archive AN-107 First Rinse."." The second rinse should be done with 2 liters of filtered, distilled water, and the final rinse with 1 liter filtered, distilled water. The second and third rinses should be collected separately from the first in the alkaline rinse storage container. Conduct the acid wash of the CUF unit with IM HNO3/0.1-0.2M Citric Acid as described in the CUF operating procedure. The acidic solutions should be allowed to sit in the CUF overnight. When drained, the acidic solutions should be placed in a separate container.

5.4.4 The CUF should be drained according to "10.0 Draining the system" operation in BNFLTP-29953-020 and rinsed at least 3 times with filtered, distilled water to bring the pH back up to neutral. The acidic solutions should be placed in a separate container from the alkaline ones.

5.4.4 Perform "1.0 Start-Up" operations in BNFL-TP-29953-020 with 1.0 liter of filtered, distilled water. 
5.4.5 Perform "6.0 Back pulsing" operations in BNFL-TP-29953-020.

5.4.6 Shut off the system and conduct the "10.0 Draining the system" operation in BNFL-TP29953-020.

5.4.7 Perform "1.0 Start-Up" operations in BNFL-TP-29953-020 with 1.0 liter of filtered, distilled water.

5.4.8 Conduct the "3.0 Operation during Ultrafilter Recycle Mode" operations in BNFL-TP29953-020 using the conditions below. Filtrate flow rate should be monitored and data collected in the operating procedure. Each test should be performed for only 20 minutes and the system should be back pulsed. After each condition, the test engineer should initial and date the table below.

\begin{tabular}{|c|c|c|c|}
\hline Condition & Flowrate (gpm) & $\begin{array}{c}\text { Transmembrane } \\
\text { Pressure (psig) }\end{array}$ & $\begin{array}{c}\text { Initial and date } \\
\text { when complete }\end{array}$ \\
\hline 1 & 4.20 & 10 & \\
\hline 2 & 4.20 & 20 & \\
\hline 3 & 4.20 & 30 & \\
\hline
\end{tabular}

5.4.9 Shut off the system and conduct the "10.0 Draining the system" operation in BNFL-TP29953-020.

\subsection{Sr/TRU Removal by Permanganate Treatment}

NOTE: Sections 5.5, 5.6 and 5.7 can be completed after Step 5.4.2

5.5.1 Setup the ppt reaction equipment as specified. The precipitation is to be conducted in a $2 \mathrm{~L}$ flask. Secondary containment should be used to allow recovery from a possible breach of the $2 \mathrm{~L}$ flask. Place stir bar in flask.

Shake the bottle of waste thoroughly and collect two $20 \mathrm{~mL}$ one in the vial labeled Tc IX-01 and one in MN-21. Shake and transfer the remaining waste to the reaction vessel. There should be some solids. If solids are observed, record observation or notify the cognizant scientist/engineer (record observations in the LRB).

5.5.2 Record the weight( 5 ) of the empty bottle with lid in the spaces provided below. Calculate the amount of material transferred to the reaction vessel. The cognizant scientist/engineer will calculate the amount of strontium and permanganate solution to add.

AN-107

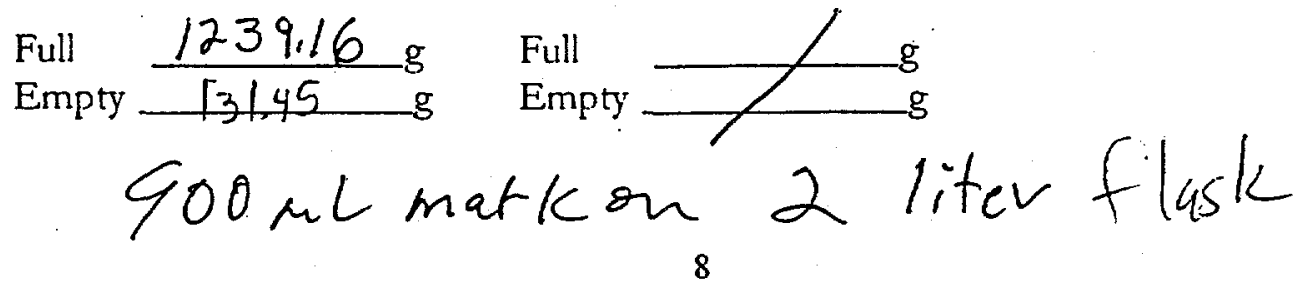


Added

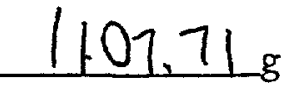

Added

Total

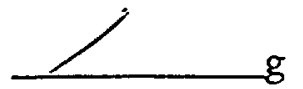

Density $=$

$\mathrm{g} / \mathrm{mL}$ total volume added

$\mathrm{mL}$

5.5.3 Calculate the amount of strontium and permanganate solution to add. The cognizant scientist/engineer calculations are to be reviewed prior to the additions, and retained in the project files.

$$
75 \mathrm{~mL} S \mathrm{SO}\left(\mathrm{NO}_{3}\right)_{2}(\mathrm{~m})
$$

Record here and below 50. mL Density $\mathrm{g} / \mathrm{mL}$ Weight

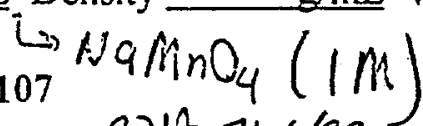

\subsection{Permanganate Treatment of AN-107

5.6.1 Turn on stirrer. Turn heat on and heat $50+56$.

5.6.2 While continuously stirring the waste sample, personnel are to slowly add $75 \mathrm{~mL}$ of $1.0 \mathrm{M} \mathrm{Sr}\left(\mathrm{NO}_{3}\right)_{2}$ solution per each liter of $\mathrm{AN}-107$ sample. (based upon BNF-003-98-0023, add

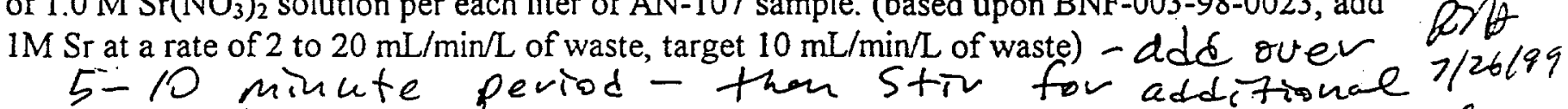
Tare bottle of $1 \mathrm{MSr} \frac{184.3352}{0.5} \quad 5-10$ minates cutil well mived. Tare Empty bottle Weight Added 100.522 83.813

5.6.4 Heat the waste nirty at $50 \pm 5^{\circ} \mathrm{C}$ with stirring for 2 hours atter completing the addition Ththe

5.6.5 Slowly add $50 \mathrm{~mL}$ of $1 \mathrm{M} \mathrm{NaMnO}_{4}$ solution per each liter of $\mathrm{AN}-107$ sample. (based upon BNF-003-98-0023, add $1 \mathrm{M} \mathrm{NaMnO}_{4}$ at a rate of 2 to $20 \mathrm{~mL} / \mathrm{min} / \mathrm{L}$ of waste, target $10 \mathrm{~mL} / \mathrm{min} / \mathrm{L}$ of waste) add oven a 5-10 mixute period-then stiv for an additibural 5-10 minutes antil well mixed.

Tare bottle of $1 \mathrm{M} \mathrm{NaMnO4} 112.1823$ g

Tare Empty bottle 590757.8579

Weight Added _ $54.325 \mathrm{~g}$

5.6.6 Heat the waste mixture at $50 \pm 5^{\circ} \mathrm{C}$ with stirring for 2 hours after completing the addition of the $\mathrm{NaMnO}_{4}$.

5.6.6 Turn off the stirrer and allow the waste to cool to $25 \pm 5^{\circ} \mathrm{C}$. If possible, use a video recorder to document the settling behavior of the waste mixture. Record the volume of settled solids. Not performeanu to $8 / 3 / 99$

5.6.7 Stir waste dCollect two $20 \mathrm{~mL}$ samples, one in TC IX-02 and one in MN-22. -of sup eirnati after coling/setting.

5.7 Completion of Permanganate Treatment/Precipitation and Startup of CUF Testing 
(The solids removal from the reaction vessel is to occur as soon after precipitation as possible. If for some reason, a delay is required between precipitation and solids removal, transfer the slurry from the reaction vessel to 1 or $2-1$ liter poly bottles as needed.)

5.7.1 Conduct the "1.0 Start-Up" operations in BNFL-TP-29953-020 using permanganate treated AN-107. Record the weight of the reaction-vessel and ppt. Shake/mix the waste slurry thoroughly before transferring to the slurry reservior. There may be some solids left in the flask that is difficult to transfer. If so, consult with the cognizant scientist/engineer on recovering these solids. DI water addition/washing could be attempted if the amount of solids looks significant. Record the method of recovery in the LRB.

5.7.3 Record the weight(s) of empty reaction vessel or sample bottles.

\section{Vessel and ppted AN-107 2204.704 g \\ Empty vessel $102434 \mathrm{~g}$ \\ $A D D E D \Perp 80.40 \mathrm{~g}$}

5.7.3 Record the level in the slurry reservoir sight glass.

Height Not seen_ inches

\subsection{CUF Operation: Sr/TRU Precipitate Removal Test with Archived AN-107}

5.8.1 Conduct the "3.0 Operation during Ultrafilter Recycle Mode" operations in BNFL-TP29953-020 using the conditions below. Filtrate flow rate should be monitored and data collected as specified in the operating procedure. After each condition, the test engineer should initial and date the table below. . If no filtrate flow occurs or the filtrate flow is less than $10 \mathrm{~mL} / \mathrm{min}$, discontinue testing and move to the next condition. After each condition, the test engineer should initial and date the table below.

NOTE: Samples of filtrate should be taken within the first 10 minutes of operation during Condition 1 and 30 minutes into each of the other 5 conditions. A slurry sample should be taken during Condition 3 . Instructions for sampling are provided below.

NOTE: Test conditions below are suggested and all conditions do not need to be run, make sure condition 1 is run for 1 hour, other conditions should be run at least 20 minutes, run as many of the conditions as time allows.

\begin{tabular}{|c|c|c|c|}
\hline \begin{tabular}{c} 
Condition \\
\hline 1
\end{tabular} & Flowrate $(\mathrm{gpm})$ & $\begin{array}{c}\text { Transmembrane } \\
\text { Pressure (psig) }\end{array}$ & $\begin{array}{c}\text { Initial and date } \\
\text { when complete }\end{array}$ \\
\hline 2 & 4.20 & 55 & 7 \\
\hline 3 & 4.20 & 40 & $7 / 27 / 99$ \\
\hline 4 & 4.20 & 70 & $7 / 7244$ \\
\hline 5 & 3.13 & 55 & $7 / 27 / 45$ \\
\hline
\end{tabular}


5.8.2 Obtain 1 filtrate sample of at least 10 grams within the first 10 minutes of operation (during Condition 1). Record the weight and sample number in Data Sheet 3 . These will be used for chemical and radiochemical analyses.

5.8.3 Obtain filtrate samples of at least 5 grams each following "8.0 Filtrate Sampling" in BNFLTP-29953-020 and using the pre-labeled sample vials after approximately 30 minutes of operation for each condition. Record the weight and sample number in Data Sheet 3. These will be used for chemical and radiochemical analyses.

5.8.4 Obtain 2 slurry samples of at least 10 grams following "7.0 Slurry Sampling" in BNFL-TP29953-020. The samples should be taken after condition 3 . The first slurry sample should not be saved, but dumped back into the tank. Record the weight and sample number in Data Sheet 3.

\subsubsection{Tare weigh a prelabeled $20 \mathrm{~mL}$ sample vial.}

5.8.6 Using a pipet, transfer $2 \mathrm{~mL}$ from each of the 6 filtrate sample vials taken previously in step 5.8.3 into the sample vial. Record the weight and sample number in Data Sheet 3. This composite will be used for chemical and radiochemical analyses.

\subsubsection{Conduct the "11.0 Shutting down" operation in BNFL-TP-29953-020.}

\subsection{Sr/TRU Precipitate Removal Test: Rinsing and Draining the System}

5.9.1 Tare the 1 liter bottle labeled, "MNO4 CUF Slurry."

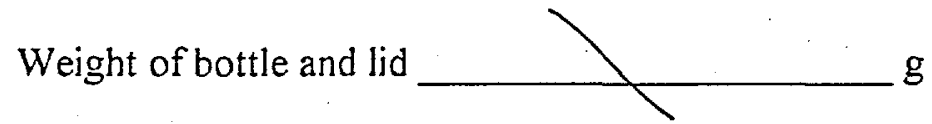

5.9.2 Conduct the "10.0 Draining the system" operation in BNFL-TP-29953-020. Collect liquid in 1 liter bottle. Make sure as much materials as possible has been collected. This materials will be used for the permanganate treatment. Weigh bottle after all liquid has been removed.

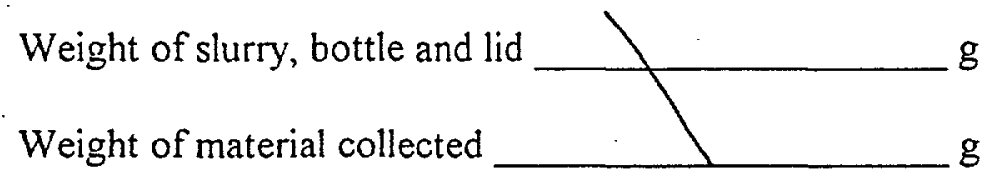

$$
2850 \mathrm{mb} \text { reaural }
$$

5.9.3 Conduct the "9.0 Rinsing the system" operation in BNFL-TP-29953-020. The first rinse should be done with 1 liter of distilled water. This liquid should be collected and saved in the container labeled "MNO4 CUF First Rinse." The second rinse should be done with 2 liters of filtered, distilled water, and the final rinse with 1 liter filtered, distilled water. The second and third rinses should be collected separately from the first in the alkaline rinse storage container. Conduct the acid wash of the CUF unit with 1M HNO3/0.1-0.2M Citric Acid as described in the 
CUF operating procedure. The acidic solutions should be allowed to sit in the CUF overnight. When drained, the acidic solutions should be placed in a separate container.

5.9.4 The CUF should be drained according to "10.0 Draining the system" operation in BNFLTP-29953-020 and rinsed at least 3 times with filtered, distilled water to bring the pH back up to neutral. The acidic solutions should be placed in a separate container from the alkaline ones.

5.9.4 Perform "1.0 Start-Up" operations in BNFL-TP-29953-020 with 1.0 liter of filtered, distilled water.

5.9.5 Perform "6.0 Back pulsing" operations in BNFL-TP-29953-020.

5.9.6 Shut off the system and conduct the "10.0 Draining the system" operation in BNFL-TP29953-020.

5.9.7 Perform "1.0 Start-Up" operations in BNFL-TP-29953-020 with 1.0 liter of filtered, distilled water.

5.9.8 Conduct the "3.0 Operation during Ultrafilter Recycle Mode" operations in BNFL-TP29953-020 using the conditions below. Filtrate flow rate should be monitored and data collected in the operating procedure. Each test should be performed for only 20 minutes and the system should be back pulsed. After each condition, the test engineer should initial and date the table below.

\begin{tabular}{|c|c|c|c|}
\hline Condition & Flowrate $(\mathrm{gpm})$ & $\begin{array}{c}\text { Transmembrane } \\
\text { Pressure (psig) }\end{array}$ & $\begin{array}{c}\text { Initial and date } \\
\text { when complete }\end{array}$ \\
\hline 1 & 4.20 & 10 & \\
\hline 2 & 4.20 & 20 & \\
\hline 3 & 4.20 & 30 & \\
\hline
\end{tabular}

5.9.9 Shut off the system and conduct the "10.0 Draining the system" operation in BNFL-TP29953-020.

\subsection{Experimental Clean Up and Sample Disposition.}

Clean up all of the equipment used.

Do not discard any samples without written instructions from the task manager. Duplicate samples were collected at all sampling points, but only primary samples submitted for analyses. The duplicates are to be retained until review of the analytical data is completed and notification is writing is received to dispose of these samples. The alkaline and acid CUF wash solutions should be disposed of properly.

\subsection{Sample Analysis}


The point of contact for physical property sample analysis of the slurry samples is Paul Bredt. The point of contact for the sample analysis of the filtrate, wash, and filtered solids samples is Mike Urie and Rick Steele.

\subsection{Chemical and Radiochemical Analysis}

The points of contact for the sample analysis of the slurry and filtrate samples are Mike Urie and Rick Steele.

The following samples should be transferred to the SAL hot cells for prep work and analysis for the entrained solids test if the average filtrate flow at any condition is $>40 \mathrm{~mL} / \mathrm{min}$ :

- One sample of slurry from CUF described in Step 5.3.4

- Initial sample of filtrate taken during Condition 1 described in Step 5.3.2

- Final sample of filtrate taken during Condition 6 described in Step 5.3.3

- Composite filtrate prepared in Step 5.3.6

The following will be performed on the above samples if they are analyzed: TOC/TIC on the original sample, then acid digest followed by GEA, Sr-90 analysis and ICP-AES.

The two samples labeled Tc IX-01 and Tc IX-02 should be transfer to the SAL and Dean Kurath notified of their arrival. These samples will be used for batch contacts with Tc ion exchange resins.

The two $20 \mathrm{~g}$ samples, MN-21 and MN-22 should be transferred to the SAL hot cells for prep work and analysis for the Sr/TRU precipitation test. Once in SAL the samples should be filtered with 0.45 micron disposable syringe filter as soon as possible (or filter in A-cell when taken).

The following samples should be transferred to the SAL hot cells for prep work and analysis from the Sr/TRU Precipitate Removal test:

- Initial sample of filtrate taken during Condition 1 described in Step 5.8.2 (ICP, Sr and GEA)

- Final sample of filtrate taken during Condition 6 described in Step 5.8.3 (ICP, Sr and GEA)

- Composite filtrate prepared in Step 5.8.6 (ICP, Sr and GEA)

- One sample of slurry from CUF described in Step 5.8.4 (acid digest-ICP, Sr and GEA)

Table 3 below shows the sample analysis list for the Sr/TRU precipitation and SR/TRU solids removal test. The table lists the analyses to be performed on samples generated from this test instruction. 
Table 3. Samples and Their Required Analyses (if vial numbers differ, cross out and show actual 3)

\begin{tabular}{|l|c|c|c|c|}
\hline \multicolumn{1}{|c|}{ Process Variable } & $\begin{array}{c}\text { Vial } \\
\text { ID }\end{array}$ & Sample Type & Sample Preparation & Analysis Description ${ }^{(a)}$ \\
\hline AN-107 after entrained solids & MN-21 & as received & 0.45 um filter, acid digest & $\mathrm{Sr} / \mathrm{Am},[\mathrm{OH}]$ \\
\hline AN-107 after Sr/TRU PPT & $\mathrm{MN}-22$ & ppted waste & 0.45 um filter, acid digest & TOC/TIC, Sr/Am, ICP, [OH] \\
\hline $1^{\text {st CUF Permeate Sr/TRU PPT }}$ & $\mathrm{MN}-23$ & CUF filtrate & acid digest & $\mathrm{Sr} / \mathrm{Am}, \mathrm{ICP}$ \\
\hline Final CUF Permeate & $\mathrm{MN}-24$ & CUF filtrate & acid digest & $\mathrm{Sr} / \mathrm{Am}, \mathrm{ICP}$ \\
\hline Composite CUF Permeate & $\mathrm{MN}-25$ & Filtrate & acid digest & $\mathrm{Sr} / \mathrm{Am}, \mathrm{ICP}$ \\
\hline Final CUF Slurry & $\mathrm{MN}-26$ & Slurry & acid digest & $\mathrm{Sr} / \mathrm{Am}, \mathrm{ICP}$ \\
\hline
\end{tabular}

(a) Descriptions of analyses are contained in Table 4.

Table 4. Description of Analyses

\begin{tabular}{|l|l|l|}
\hline \multicolumn{1}{|c|}{ Constituent } & \multicolumn{1}{|c|}{ Analysis Method } & \multicolumn{1}{c|}{ PNNL Procedure No. } \\
\hline Americium-241, Eu isotopes & GEA & PNL-ALO-450 \\
\hline Strontium-90 (Yttrium-90) & Separations and Beta Counting & PNL-ALO-476/431 \\
\hline Hydroxide & $\begin{array}{l}\text { EPA SW-846 Modified Method, } \\
310(3)\end{array}$ & PNL-ALO-228 \\
\hline TOC/TIC & & \\
\hline Metal Ions (see Table 5 list) & ICP-AES & PNL-ALO-211/280 \\
\hline
\end{tabular}


Table 5. Analytical Requirements for Supernate/Filtrate and Centrifuged Solids

\begin{tabular}{|c|c|c|c|}
\hline Analyte & $\begin{array}{c}\text { Centrifuged Solids } \\
\text { Minimum Reportable } \\
\text { Quantity microCi/gm }\end{array}$ & $\begin{array}{c}\text { Supernate/Filtrate } \\
\text { Minimum Reportable } \\
\text { Quantity microCi/ml } \\
\end{array}$ & Analysis Method \\
\hline Strontium-90 & $7.01 E+01$ & $1.5 \mathrm{E}-01$ & $\begin{array}{c}\text { Chemical Separation \& Beta } \\
\text { Count }\end{array}$ \\
\hline Americium-241 & $1.2 \mathrm{E}-03$ & 7.2E-04 & GEA \\
\hline & microgin/gm & microgm $/ \mathrm{ml}$ & \\
\hline $\mathrm{Al}$ & $3.3 E+02$ & $7.5 \mathrm{E}+01$ & \multirow{21}{*}{$\begin{array}{l}\text { Acid Digestion followed by } \\
\text { ICP-AES }\end{array}$} \\
\hline $\mathrm{Ba}$ & $6.0 E+02$ & $7.8 \mathrm{E}+01$ & \\
\hline $\mathrm{Ca}$ & $1.8 \mathrm{E}+02$ & $1.5 \mathrm{E}+02$ & \\
\hline $\mathrm{Cd}$ & $1.1 \mathrm{E}+01$ & $7.5 \mathrm{E}+00$ & \\
\hline $\mathrm{Co}$ & $3.0 \mathrm{E}+00$ & $3.0 \mathrm{E}+01$ & \\
\hline $\mathrm{Cr}$ & $1.2 \mathrm{E}+02$ & $1.5 \mathrm{E}+01$ & \\
\hline $\mathrm{Cu}$ & $1.8 \mathrm{E}+01$ & $1.7 \mathrm{E}+01$ & \\
\hline Eu & NA & $\mathrm{NA}$ & \\
\hline $\mathrm{Fe}$ & $1.4 \mathrm{E}+02$ & $1.5 \mathrm{E}+02$ & \\
\hline $\mathrm{K}$ & $1.5 \mathrm{E}+03$ & $2.0 \mathrm{E}+02$ & \\
\hline $\mathrm{La}$ & $6.0 \mathrm{E}+01$ & $3.5 \mathrm{E}+01$ & \\
\hline $\mathrm{Mg}$ & $5.4 \mathrm{E}+02$ & $1.5 \mathrm{E}+02$ & \\
\hline $\mathrm{Mn}$ & $3.0 \mathrm{E}+02$ & $1.5 \mathrm{E}+02$ & \\
\hline Mo & $6.0 \mathrm{E}+00$ & $9.0 \mathrm{E}+01$ & \\
\hline $\mathrm{Na}$ & $1.5 \mathrm{E}+02$ & $7.5 \mathrm{E}+01$ & \\
\hline $\mathrm{Ni}$ & $1.6 \mathrm{E}+02$ & $3.0 \mathrm{E}+01$ & \\
\hline $\mathrm{Pb}$ & $6.0 \mathrm{E}+02$ & $3.0 \mathrm{E}+02$ & \\
\hline $\mathrm{Si}$ & $3.0 \mathrm{E}+03$ & $1.7 \mathrm{E}+02$ & \\
\hline $\mathrm{Sr}$ & $3.0 \mathrm{E}+02$ & $8.7 E+01$ & \\
\hline $\mathrm{Ti}$ & $1.5 \mathrm{E}+02$ & $1.7 \mathrm{E}+01$ & \\
\hline $\mathrm{U}$ & $6.0 \mathrm{E}+02$ & $6.0 E+02$ & \\
\hline$\overline{\mathrm{Zn}}$ & $6.0 E+00$ & $1.65 \mathrm{E}+01$ & \\
\hline $\mathrm{OH}-$ & & $0.05 \mathrm{M}$ & \\
\hline
\end{tabular}


Date:

Tank Number:

Filter:

Test Conditions:

Operator:

Test Engineer: Jul 16, 1999

water Tess

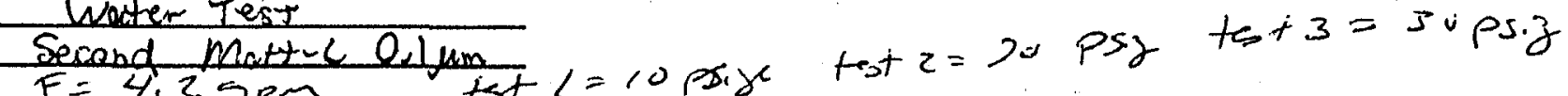

T. Rinhart

Lk Jaguela kkp Bry ks
Jask $213: 25$ 29953

p.l of S

See

$T P-29953-041$

\begin{tabular}{|c|c|c|c|c|c|c|c|c|c|c|c|c|}
\hline $\begin{array}{l}\text { Test } \\
\text { No. }\end{array}$ & Time & $\begin{array}{l}\text { Chiller } \\
\text { Temp. }\end{array}$ & $\begin{array}{l}\text { Slurry } \\
\text { Temp. }\end{array}$ & $\left|\begin{array}{c}\text { Slurry loop } \\
\text { Flowrate }\end{array}\right|$ & $\begin{array}{c}\begin{array}{c}\text { Filter Outlet } \\
\text { Pressure }\end{array} \\
\end{array}$ & $\begin{array}{l}\text { Permeate } \\
\text { Pressure }\end{array}$ & \begin{tabular}{|c|c} 
Filter inlet \\
Pressure
\end{tabular} & $\begin{array}{r}\text { Filtra } \\
\text { Volume }\end{array}$ & $\begin{array}{l}\text { te Flow } \\
\text { Time }\end{array}$ & $\begin{array}{l}\text { rate } \\
\text { Flowrate }\end{array}$ & $\begin{array}{l}\text { Tank } \\
\text { Level }\end{array}$ & Comments \\
\hline 2 & 13.03 & & 23.5 & $3 \mathrm{gpon}$ & Not pxerahp & 2 & 20 & & & & $\bar{L}$ & $R_{3}$ rameter $=30$ \\
\hline 2 & $13: 08$ & & & & $\vec{C}$ & c & 20 & 1 & & & & R y a d 26 \\
\hline 2 & $13: 16$ & & & & & 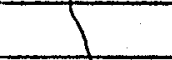 & 18 & & & & & Rotanote $=24$ \\
\hline 2 & $1.3: 23$ & & & & & e & 18 & & & & & Retamator $=25$ \\
\hline 2 & $13: 32$ & & & 4 & t & 2 & 20 & & & 1 & & Rotrmater $=27$ \\
\hline 2 & $13: 49$ & 105 & 26.7 & & \pm & 3 & 20 & & T & & & Ratameter $=27$ \\
\hline 2 & $13: 57$ & 25.5 & 24,6 & $4 g p m$ & & 3 & 20 & & & & & $R=25$ \\
\hline 2 & $14: 02$ & 23,8 & 22,5 & $490 . n$ & & 3 & 20 & & & $\nabla$ & & $R=24$ \\
\hline 2 & $14: 03$ & 23.5 & 22.1 & Ycpm & & & 20 & & & $\triangle$ & & $R=24$ \\
\hline$I$ & $14: 12$ & 23,5 & 22,7 & $-4 \mathrm{spm}$ & & & 10 & & & 7 & & $R=10$ \\
\hline 1 & $14: 15$ & 24.6 & 23.4 & $-480 m$ & & & 10 & & & & & $R=10$ \\
\hline$i$ & $14: 19$ & 24.7 & 24,2 & -4 gen & & & $\sim 9$ & & & & & $R=9$ \\
\hline 1 & $14: 22$ & 25,4 & 24,9 & $1<$ spen & & & 12 & & Z & & & $R=10$ \\
\hline 1 & $14: 26$ & 25.9 & 25.4 & $-4 \mathrm{gen}$ & & & $T .5$ & & 1 & & & $R=10$ \\
\hline 1 & $14: 30$ & 25.5 & 24.6 & $24 \mathrm{sen}$ & & & 4.5 & & & & & $R=q$ \\
\hline$i$ & $14: 32$ & 25.0 & 23.7 & 24 spen & & & 9,5 & ד & & & & $R=9$ \\
\hline 3 & $44: 40$ & 23.2 & 22.2 & $24 \mathrm{sem}$ & & 4 & 30,0 & 7 & & & & $R=45$ \\
\hline 3 & $14 ! 42$ & 23.9 & 23,2 & ncispm & & 4 & 300 & 7 & & & & $R=40$ \\
\hline 3 & $4: 47$ & 25.0 & $24,5 \cdot$ & $4 \operatorname{sen}$ & & 3 & 30.0 & 7 & & & & $R=39 \quad p e r$ \\
\hline 3 & $14: 53$ & 26.1 & 25.5 & $-4 \mathrm{sen}$ & & 3 & 30.0 & & & & & $l=38-9+3 x$ \\
\hline 3 & $15: 00$ & 24.3 & 23,0 & $-4 g p m$ & & 3 & 30.0 & & & & & $R=37$ \\
\hline
\end{tabular}




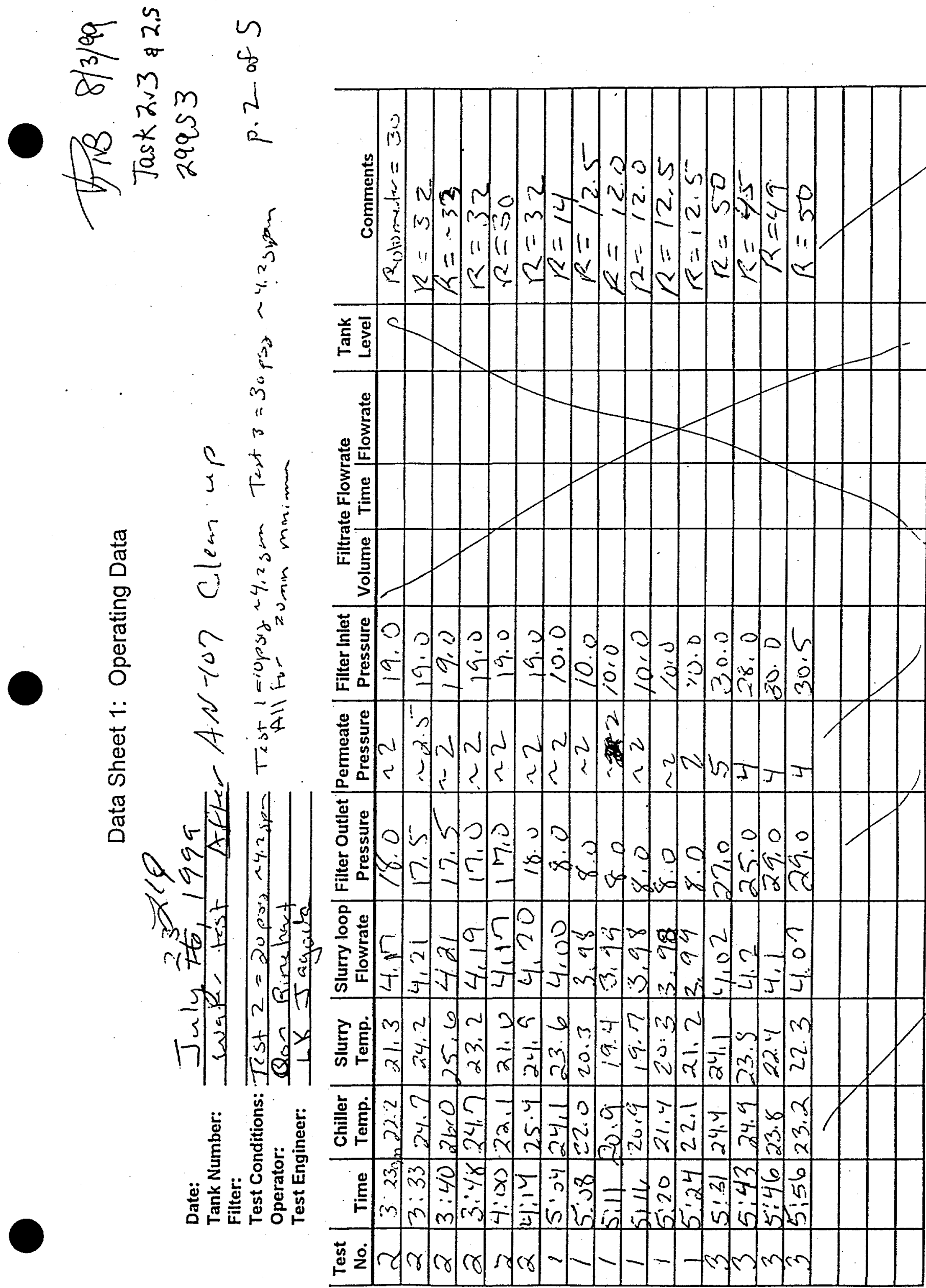


Date:

Tank Number:

July 27,1999

Filter:

Av-10? Archive Se/truppt

Test Conditions:

Operator: 0.1 un Motr $L$ (2nd)

Test Engineer:

$$
\begin{aligned}
& \text { KP Branks } \\
& \text { R Letwau }
\end{aligned}
$$

\begin{tabular}{|c|c|c|c|c|c|c|c|c|c|c|c|c|}
\hline $\begin{array}{l}\text { Test } \\
\text { No. }\end{array}$ & Time & $\begin{array}{l}\text { Chiller } \\
\text { Temp. }\end{array}$ & $\begin{array}{l}\text { Slurry } \\
\text { Temp. }\end{array}$ & $\mid \begin{array}{c}\text { Slurry loop } \\
\text { Flowrate }\end{array}$ & $\begin{array}{c}\text { Filter Outlet } \\
\text { Pressure }\end{array}$ & $\begin{array}{c}\text { Permeate } \\
\text { Pressure }\end{array}$ & $\begin{array}{c}\text { Filter Inlet } \\
\text { Pressure }\end{array}$ & $\begin{array}{c}\text { Filtr } \\
\text { Volume }\end{array}$ & $\begin{array}{l}\text { ate Flowr } \\
\text { Time }\end{array}$ & $\begin{array}{l}\text { ate } \\
\text { Flowrate }\end{array}$ & $\begin{array}{l}\text { Tank } \\
\text { Level }\end{array}$ & Comments \\
\hline 1 & $10: 01$ & 29.4 & 28.4 & 3.9 & 51 & 2 & 54 & 40 & 7.44 & 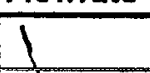 & & Ratameter $=10$ \\
\hline 1 & $10: 07$ & 25.3 & 23.8 & 3.8 & $S^{2}$ & 2 & 56 & 40 & 14.36 & & 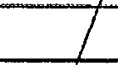 & Ratametar= 6 \\
\hline 1 & $10: 11$ & 23.6 & 21.9 & 3.85 & 52 & 2 & 56 & 30 & 12.83 & & $1-$ & Bozameters 5 \\
\hline$\perp$ & $10: 22$ & 25,5 & 25.1 & 3.9 & SI & 2 & 54 & 30 & 18.13 & & & Rotametar $=4$ \\
\hline 1 & $10: 31$ & 25.9 & 24.7 & 3.8 & 51 & 1 & 54 & 30 & 12.09 & & & Rotametor $=3-4$ \\
\hline 1 & $10: 49$ & 29,2 & 27.9 & 3,8 & 48 & 2 & 51 & 30 & 23.32 & & & \\
\hline 1 & 11102 & aff & 23.9 & 3.9 & 53 & & 57 & 30 & 28.12 & & & Ratameter $=2$ \\
\hline & $11: 09$ & Backp & Ased $f$ & wice at & 20 esi & & & & & & & \\
\hline 2 & $11: 11$ & 31.4 & 32,1 & 4.1 & 37 & $\perp$ & 39.5 & 30 & 14.72 & & & Rotameter $=4$ \\
\hline 2 & $11: 22$ & 225 & 19.6 & 4.0 & 37 & 1 & 40 & 30 & 31.38 & & & Patameteros 2 \\
\hline 2 & 11:31 & 21.1 & 22.1 & 4.0 & 37 & 1 & 40 & 30 & 33.34 & & & \\
\hline 2 & $11: 41$ & 26.0 & 25.3 & 40 & 36 & 1 & 39 & 30 & 30,93 & & & Retameter $=1$ \\
\hline 2 & $11: 54$ & 223 & 20.4 & 4.0 & 37. & 1 & 40.5 & 20 & 25.44 & & & \\
\hline 2 & $12: 05$ & 23.0 & 23.7 & 4.9 & 37 & 1 & 40 & 20 & 25,97 & & & \\
\hline & $12: 08$ & Back & gulsed & twice & at $70 \mathrm{mi}$ & & & & & & & \\
\hline 3 & $12: 14$ & $26.6^{\circ}$ & 24.5 & 2,9 & 68 & 1 & 70 & 30 & 14.56 & & & Rotameter $=4$ \\
\hline & $17: 28$ & Back & ulsed & 5 times & at 70 & & & & & & & \\
\hline 3 & $12: 29$ & 22,6 & 17.9 & 27 & 72 & 1 & 74 & $3 \mathrm{Q}$ & 16.28 & & & Retameter $=4$ \\
\hline 3 & 1239 & 26.9 & 23,4 & 2.7 & 71 & $t$ & 72 & 30 & 34,60 & & & \\
\hline 3 & $12: 52$ & 25.4 & $22 i 1$ & 2.9 & 68 & 1 & 70 & 30 & 20,25 & & & \\
\hline
\end{tabular}




\section{Data Sheet 1: Operating Data}

Date: July 27, 1999

Tank Number: AN-Noh Anchive

Filter: $\quad 0.1 \mu m m_{0} H-L(2 n d$

Test Conditions:

Operator: $\frac{R \cdot L \text { RHace }}{L K \text { Jagala }}$

Test Engineer:

\begin{tabular}{|c|c|c|c|c|c|c|c|c|c|c|c|c|}
\hline $\begin{array}{l}\text { Test } \\
\text { No. }\end{array}$ & Time & $\begin{array}{l}\text { Chiller } \\
\text { Temp. }\end{array}$ & $\begin{array}{l}\text { Slurry } \\
\text { Temp. }\end{array}$ & $\begin{array}{c}\text { Sluiry loop } \\
\text { Flowrate }\end{array}$ & $\begin{array}{c}\begin{array}{c}\text { Filter Outlet } \\
\text { Pressure }\end{array} \\
\end{array}$ & $\begin{array}{c}\text { Permeate } \\
\text { Pressure }\end{array}$ & $\begin{array}{c}\text { Filter Inlet } \\
\text { Pressure } \\
\end{array}$ & $\begin{array}{r}\text { Filtra } \\
\text { Volume } \\
\end{array}$ & $\begin{array}{l}\text { te Flowra } \\
\text { Time |F }\end{array}$ & $\begin{array}{l}\text { ate } \\
\text { Flowrate }\end{array}$ & $\begin{array}{l}\text { Tank } \\
\text { Level } \\
\end{array}$ & Comm \\
\hline 5 & 5.05 & 22.1 & 190 & 2,26 & 52 & 1 & 55 & 30 & 75.10 & & & \\
\hline 6 & $5: 2.3$ & $27 \%$ & 25.5 & .3 .4 & 53 & 1 & 55 & & & $\lambda$ & & $R=4$ \\
\hline 6 & $5: 24$ & 27.4 & 25,5 & $\sim 3,4$ & 53 & 1 & 55 & 30 & 28,417 & & & $n \approx 1$ \\
\hline 6 & $5: 33$ & 26.2 & 22.4 & $\sim 3,46$ & 52 & 1 & 55 & 30 & 45,87 & & & \\
\hline 6 & 543 & 23.2 & 18.6 & -3.45 & 53 & 1 & 55 & 30 & 52.16 & & & \\
\hline 6 & 5,52 & $2 \% .4$ & 30,9 & $2-3.5$ & 52 & $L$ & 55 & 30 & 50,25 & & & \\
\hline 6 & $6: 05$ & 25.1 & 20.9 & -3.5 & 52 & 1 & 55 & 30 & 54.22 & & 5 & \\
\hline 6 & $6: 19$ & 22.9 & 18.7 & 43.5 & 52 & 1 & 55 & 30 & 58.72 & & f & \\
\hline 6 & $6: 25$ & 24,9 & 21.6 & 23.5 & 52 & 1 & 55 & 30 & 56.31 & & & \\
\hline & & & & & & 2 & & & & & & \\
\hline & & & & & & & & & & & & \\
\hline & & & & & & & 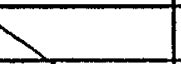 & & & & & \\
\hline & & & & & & & & & & & & 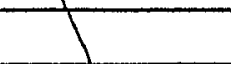 \\
\hline & & & & & & & & & & & & - \\
\hline & & & & & & & & 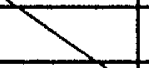 & & & & \\
\hline & & & & $\triangle$ & & & & & & & & 1 \\
\hline & & & & & & & & & $\triangle$ & & & 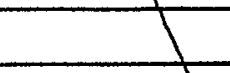 \\
\hline & & & & & $\triangle$ & & & & & 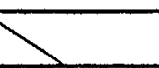 & & \\
\hline & & & & & 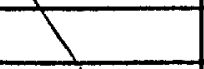 & & & & & 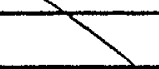 & & \\
\hline & & & & & $\nabla$ & & & & & & & \\
\hline
\end{tabular}


50

Hot Cuff

9ioupm. - Blank filter is in running r zaps

9i3o $0.05 \mu$ filter open (viopvz) r 15 psia

9:40. Bagged up old keep cleanser.

9:s5pm-shut down

$7 / 16 / 99$

8 am Turned on the pump at a Sgpm at / Dpi Running pump thru filter catndige. Wi th blank filter attached.

Pulled off water sample sent thru filter. (0.2um) (dead-end fitter). w/ $10^{\prime \prime} \mathrm{Hg}$ on outside vaculim gauge, filtered very slowly. Drained nater-no partichate, seen. Filled up a seconal time. Again filtered slowly at first then stopped. Na obvious solids an filter. Vacuum system was down. Filters quickly and no obvious solids after 3 times.

9: 50 Turned off system. Flittered material from V9 2 times in $150 \mathrm{~m}$. filter. No obvious solids on fitter.

Replaced 0.1 um Mott w/ new matt filter

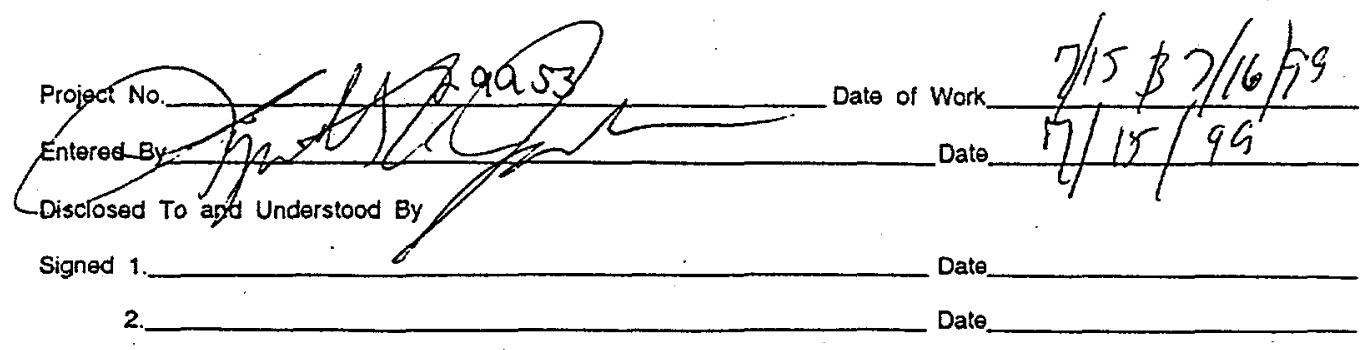


$13: 03 \quad P_{11}=20 \quad T=23.5 \quad P_{\text {out }}=2$ psi

13:08 Rotameter $=26$

13:16 Rotameter= 24

13:23 Ratameter $=25 \quad 24 \mathrm{gpm} \quad P_{\lim }=18$

13:32 Ratameter $=27 \quad P_{\text {sut }}=2 \quad P_{\text {in }}=18$

$$
T=26.7^{\circ} \mathrm{C}
$$
2:06pm - Finish test 2 (20 psig $24.28 \mathrm{pmo}$ )

Goer all Ran I hr. withury litth drop in flux!!

Back pulsed 5 times:

2:10 Starty tist (10 psig 24,2 spin)

$2: 33$ finisled tatel

Back pustiseng 5 time -

$2: 3 \pi$ statry tat \#3 (30psy 24 igspa)

3:uper finistrd tot \#3-in 20 min dropol form $\begin{aligned} & 45=R \\ & 37=R\end{aligned}$

3:20 Hadto tighto a value - done-

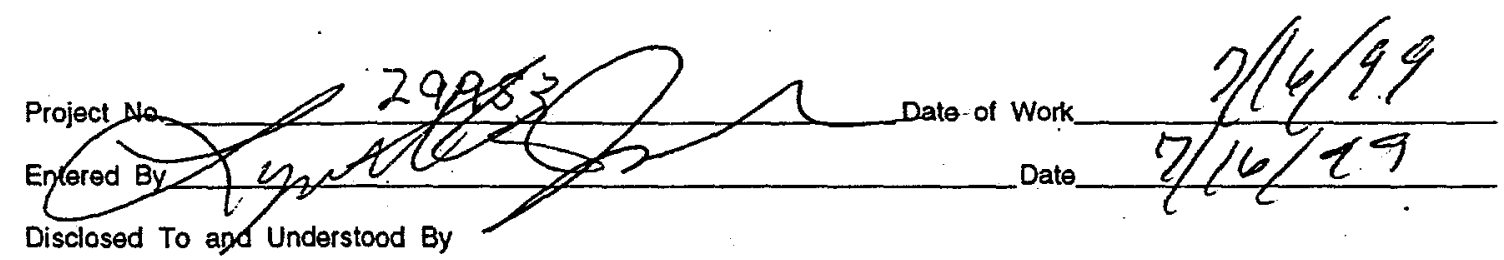

To and Understood $B$

Signed 1.

Date

Date 
$\sim 4: B 0$ pm $A N-107$ shaken and pored into
CUE

-4i45 started system

Cart get pressure above izpsig even with $V$ ' mo still closed.

Identified 2 problems

* Problem with UI opining closing - to retightely

* Building Air is low bo psigmax

si go - Played with VI until bare can reach tzopsig on System.

5:26 Turn system to setup Condition one

$$
\begin{aligned}
& F=4.2 \mathrm{gpm} \\
& P=55 \mathrm{psig} \\
& \text { Sig open } v 4 \\
& T=0 \quad R=10 \\
& T=0.49 \quad R=0 \\
&(49 \mathrm{sec})
\end{aligned}
$$

switch to glass flownety

$$
\text { close } V 6
$$

$$
\begin{aligned}
& 10 \mathrm{ml}=35 \mathrm{sec} \\
& 20 \mathrm{ml}=1: 20 \\
& 30 \mathrm{ml}=3.09
\end{aligned}
$$

closed V4 = collected sample CUFAANI07-0

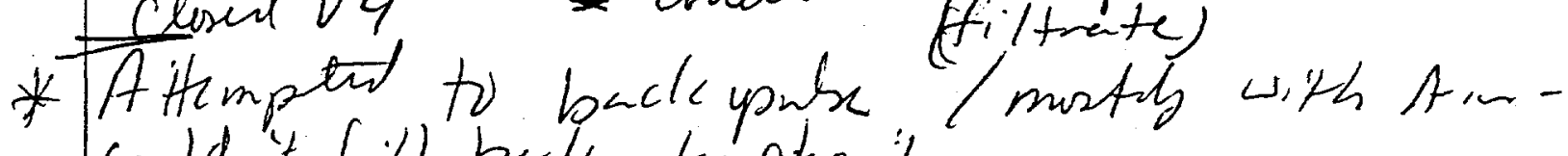
could nit fill buckle pulse chasuibu

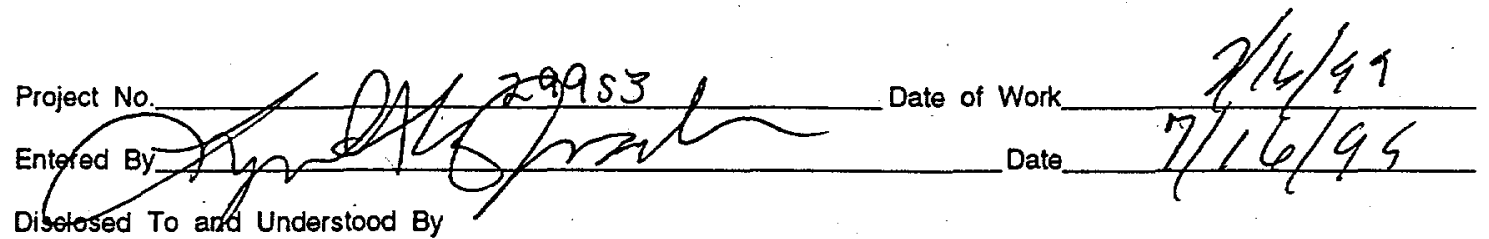

Dibstosed To and Understood By

Signed 1.

Date Date 
$7,16,199$

Set conditions to 4.28pm \$70psid

Hit open 5 me $/ \mathrm{s} /$ seconds

24 closed.

Drained system - recounted almost all volume, lost $119.56 \mathrm{~g}$.

[Probably left much af that lost weight]
in the filter as clogging solids

8:05. Ht of: $2 M \mathrm{NaOH}$ has been piping areal about 1 hr. - Tried to beck pulse 1.44 sucres - so in to add $\mathrm{H}_{2} \mathrm{O}$ from top 3 try agana.

2 back pulses from the top flux is much betta:"!

Refilling and back pulsing normally2 mure bakpulses-

opined VG -Pul $R=10$ - wassual out Rot o moth $\$$ glass flow natter for $130 \mathrm{sec}$

closed U4 - Back pulsing 6 no re tines

8:30 Drainer 9:00 Bach pushed in through top 5 tines -

$9: 12$ running -

9130 Draining - '( 3 fum top - back pubs)

9:40 rainy - iso drain i

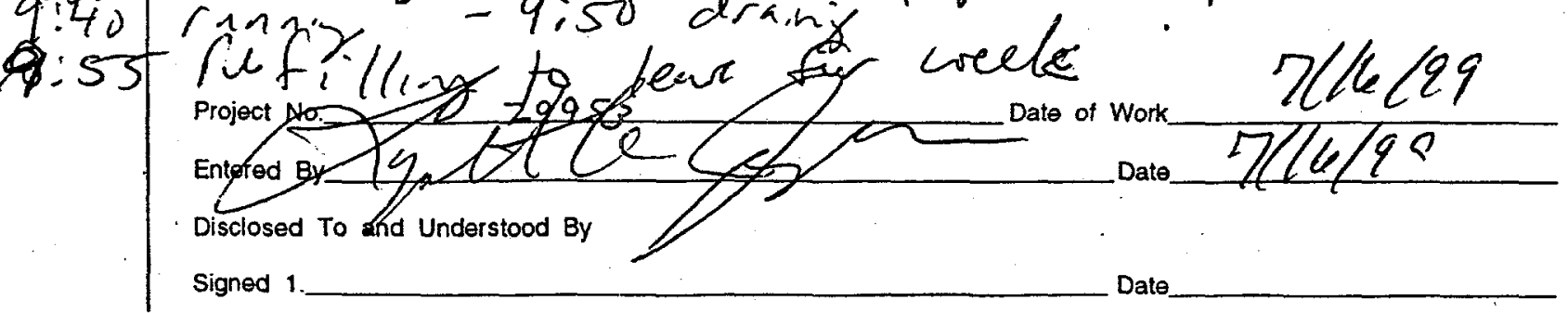


$123 / 9$

12:40 AM. System up \$ running -

Uisual inspection jore-start up shiwed water

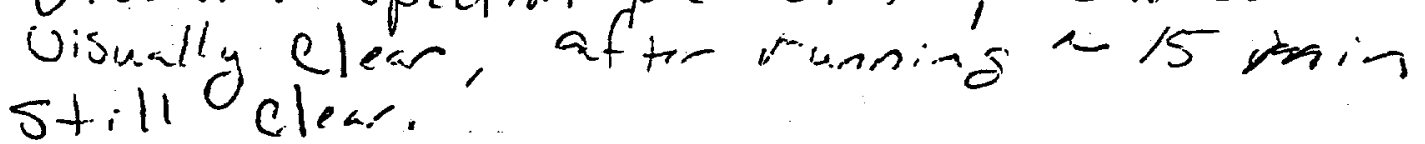

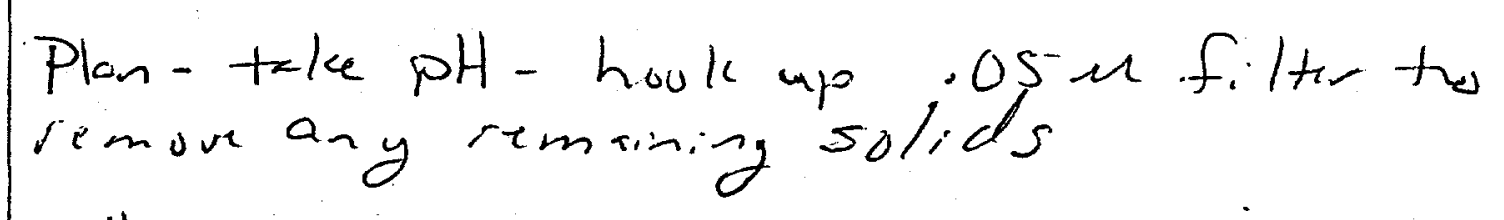

$1: 20 \quad p H \sim \leq 8.0$

$1: 40$ Prained and put 21.5 lifur of fresh 1 , 0

lis5 Runing through $0.05 \mu$ filter

zios Packled of flowrate to 25.2 gpos -

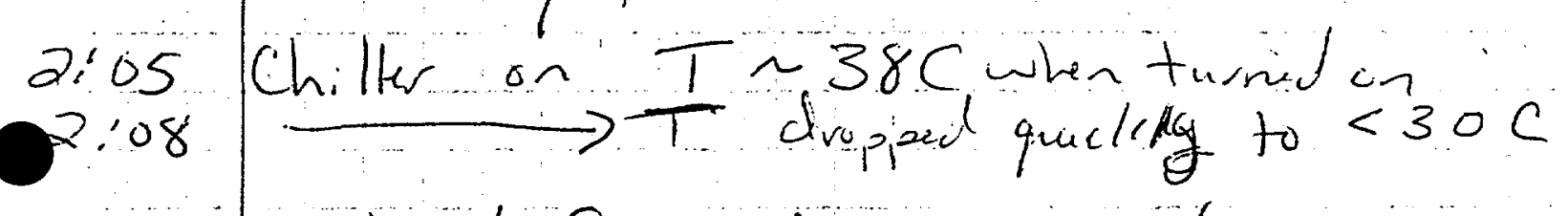

2.15 pulsed flowrate 4 timo (trying to make sure that sulids are knuckel aut of

\begin{tabular}{l|l}
$2: 48$ & pulsed flowrati 5 times \\
$3: 04$ & vio closed ( $0.05 \mathrm{~m}$ off)
\end{tabular}

$3: 06$ Condinues set to 20 psir $24.8 p m$

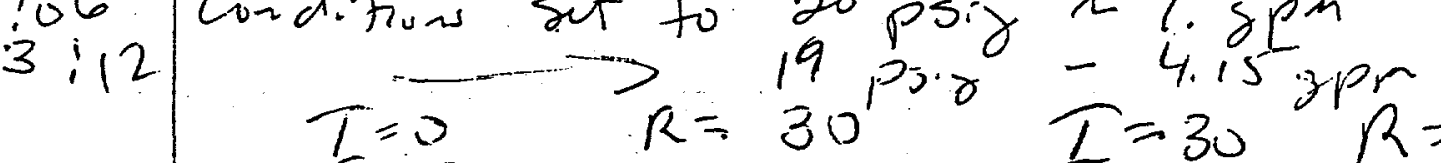

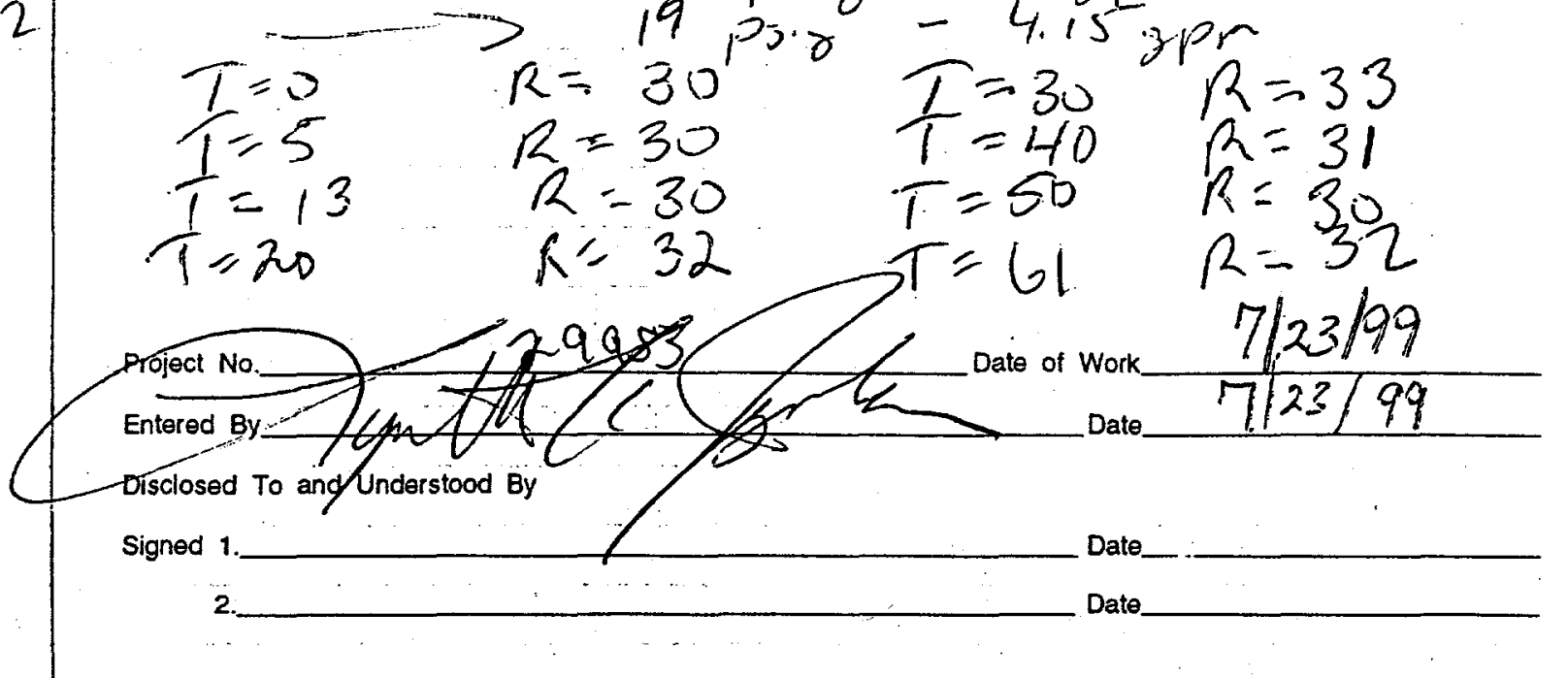


AN-10? Hot CuFF

Clem up \& wafertesting

$7 / 23 / 99$

4:20 Bate pulsed 4 fimes -

4!20 New Ganditans - Test 1 $\sim 4.0$ gph $\$ 10$ psig.

$$
T=0 \quad R=12
$$

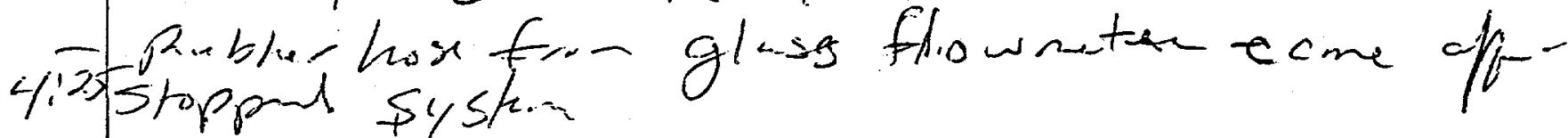

4:45 Fixied glasis fiow meter connecte-

added a $1.0 \mathrm{LE} \mathrm{H}_{2} \mathrm{O}$

siouon set conditwans to 10 psig 24,0 spin

$$
\begin{array}{ll}
T=0 & R=14 \\
T=5 & R=12.5 \\
T=14 & R=12.0 \\
T=20 . & R=12.5
\end{array}
$$

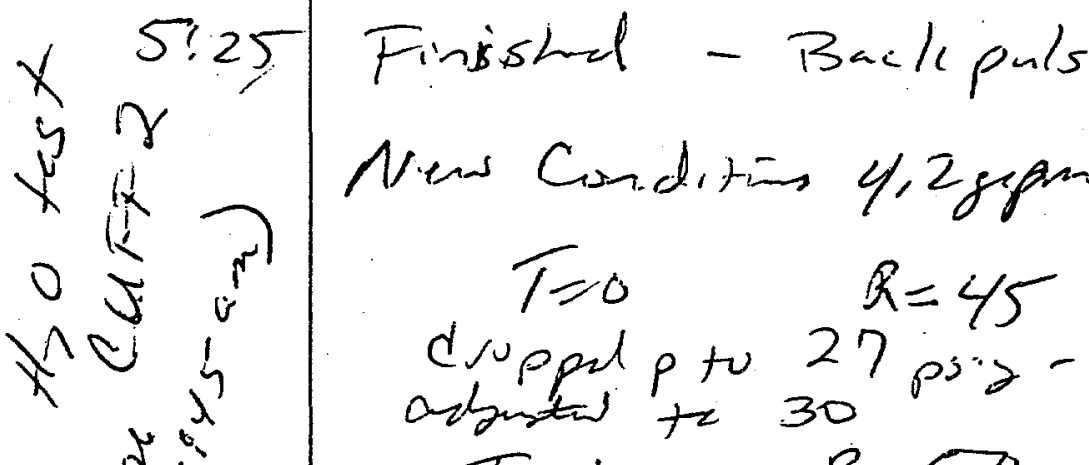

$$
\begin{aligned}
& T=1 \quad R=50
\end{aligned}
$$

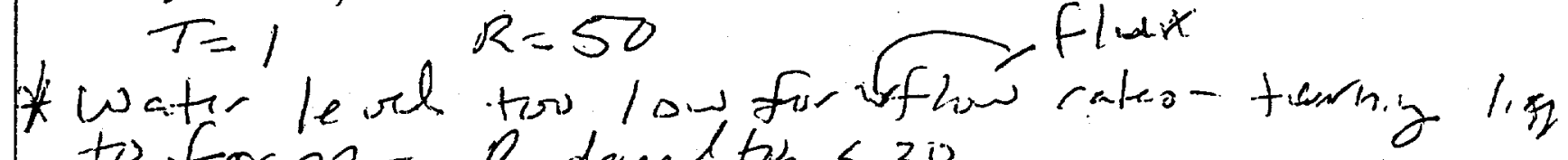
to foan - $R$ drppetso < 30

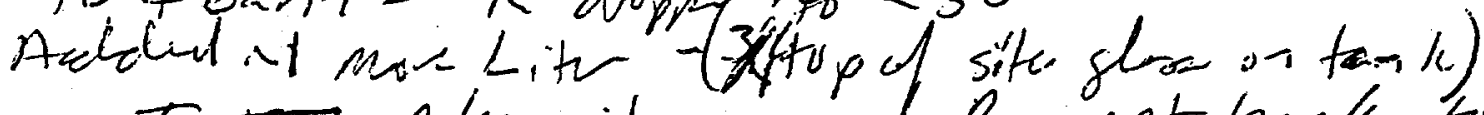

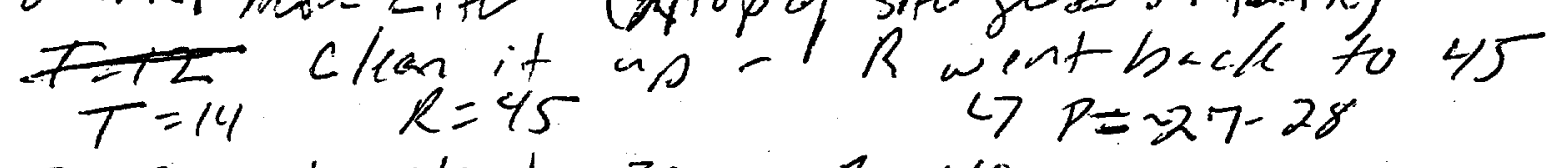

adis pressue back to $30 \quad R=49$,

Pevere

$$
\begin{array}{ll}
T=20 & \beta=49 \\
T & =25
\end{array}
$$

Project No $J=25$ Kags

Dato of Work $\frac{7 / 2 z / 99}{7 / 23 / 99}$ 
7/26/99 Compared 18" TC to Thermometer temp \& " $\alpha$ oyer is at $\sim 40-50^{\circ} \mathrm{C}$ as a check of the calibration. All measure $m$ were within $0,3^{\circ} \mathrm{C}$ of each other in a stirred beater of water.

$$
\begin{aligned}
& 18^{\prime \prime} \mathrm{TC}=54.0^{\circ} \mathrm{C} \\
& 18^{\prime \prime} T \mathrm{C}=54^{\circ} \mathrm{C} \\
& \text { Thermometer }=53.5^{\circ} \mathrm{C} \\
& \text { Thermometer }=53.7^{\circ} \mathrm{C} \\
& 6^{11} \mathrm{TC}=53.8^{\circ} \mathrm{C} \\
& 384-06-\alpha-004
\end{aligned}
$$$$
7 / 26 / 99
$$

- Sr/Tru pet $75 \mathrm{ml}$ (full) 184.3352y

In Naming $50 \mathrm{~mL}($ full) $112.1823 \mathrm{~g}$

$$
\begin{array}{ll}
T c i x-0) & 16.8953 \mathrm{~g} \\
T c \pm x-02 & 17.03019 \\
m_{n}-21 & 17.00319 \\
m_{n}-22 & 16.91839 \\
m_{n-23} & 16.8969 \mathrm{~g} \\
m_{n}-24 & 16.91479
\end{array}
$$

ibliter From AN -107 Archive -2 samples removed $220 \mathrm{~mL}$

trainer TCIX-O1 $43.654 \mathrm{~g}$ - full weight, (using cell Pm 400-calib $M N-21 \quad 41.3259$ - full weight 43.650 s (recheck on $2727 / 99)$

$41.319_{9}$ (recheck 7/27/9a)

13:39 Began adding $\operatorname{Sr}\left(\mathrm{NO}_{3}\right)_{2}$ Solution te AN-107.

$$
T=34.1^{\circ} \mathrm{C}
$$

Some of the Sr solution is lost due to difficulty pouring out of the container (a few drops)

1.3:55 Finished the addition of the. Sr solution.

stirred for 10 minutes after Sr Addition complete tuned stirrer off to ride o-

13:57 Turned off video time stamp

14:04 Turned stirrer back on

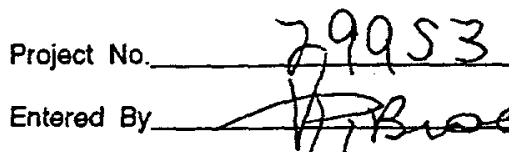

Disclosed To and Understood By
Date of Work 7/26/99

Dato $7 / 26 / 99$

Signed 1

Date Oat e 
Sr/TRU p pt

14:13 Add $\mathrm{NaMnO}_{4}$ Solution

5 $T=33.6^{\circ} \mathrm{C}$

Battles are spilling significantly - they are hard ta pour. Possibly $\sim 2 \mathrm{~mL}$ lost to side of container.

14.17 Addition is complete

14 il 9 Turned off stirrer. The str plate has quite a lot of purple $\mathrm{MnO}_{4}^{2}$.

14:29 Turned on heat $T=38^{\circ} \mathrm{C}$

14.52 Reached $50^{\circ} \mathrm{C}$

$$
15: 37 \quad T=53.2
$$

16:5 - took video of container $18: 55$ - heater off.

* Note over last 3 hrs $T=50.4 \rightarrow 51.8 \mathrm{C}$ e lowest setting on hot plate temperature climbs very slowly. About every $30 \mathrm{~min}$ (as temp approached $S 2 C$ ), the hot plate was turned off (stirrer left om) for 110 min un ti the temp dropped back to almost soc

$$
19: 21 \quad T=48.2
$$

$19: 29 T=47.4$ SCanner T.C. DAS off-

Still mixing will. - Reonoving. T.C Solid sits tighter to reduce

$129199 \quad T=35.4^{\circ} \mathrm{C}$. Put TC. back in

8.18 Took short video

8:20 Turned off stirrer to allow settling. Took external filter off.

8. SS took 2 samples from top of reaction vessel TeIX-02 \& $m_{n-2} 2$.

9:02 Weighed containers

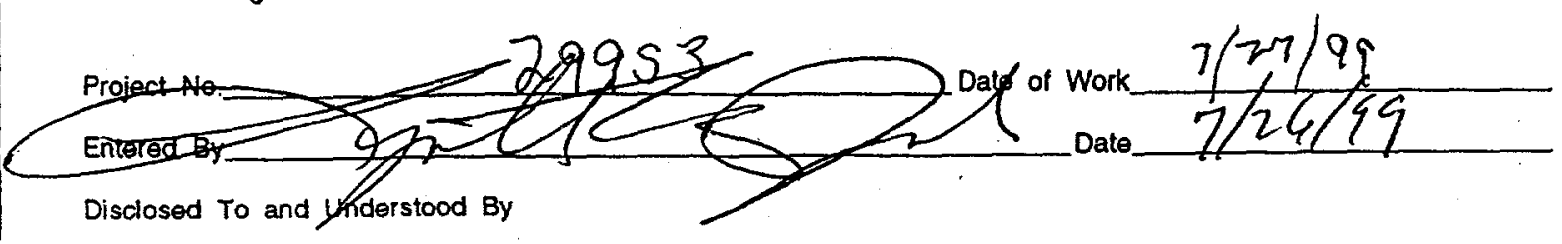


$1-1000$ am started system rotate tux very min minoring

TB 10:06 am took sample $m_{n}-23$ filtrate 10:Boum took sample Mn-24 Filtrate - \#1

Weights of full samples

$$
\begin{array}{ll}
T_{C} I x-7 & 41.345 \mathrm{~g} \\
M_{n}-22 & 40.943 \mathrm{~g} \\
M_{n}-23 & 31.553 \mathrm{~g} \\
M_{n}-24 & 30.440 \mathrm{~g}
\end{array}
$$

2 - 11:10 am started new condition

11:40 am took sample $m_{n}-25$. Filtrate 2

$M_{n-2 S} 32.508 \mathrm{~g}$ (Full sample wt)

$12.55 m_{n-26} 31.399 \mathrm{~g}$ (Full sample wt.)

1:28 For the last 30-40 min the pump has bern making a throwing sound; the pressure has fluxuated with the pump pulses. 'It has also. been drifting upton 75 s down to 67 . Ralph has adjusted it several times.

* Tore wt s taken in cell for Burka $M_{n}-27-30$

$$
\begin{aligned}
& m_{n}-27=16.903 \\
& m_{n}=28=17.098 \\
& m_{n}-29=16.950 \\
& m_{n}=30=16.961
\end{aligned}
$$

Test condition. 3 ended @ : 29-Backpulsing Tines lisps - Taking 2 slurry Stopples. Sample $m_{n}-27=28.845$ (sample + slutty)

* After dumping. first pull back into tank there was Slwryt some residue in the vial which becarothe part of sample. Project No 29953 Date of Work_ $7 / 27 / 99$ Entered By Date $7 / 27 / 99$ Disclosed To and Understood By Signed Date

2. Date 
AN-107 Archive testing

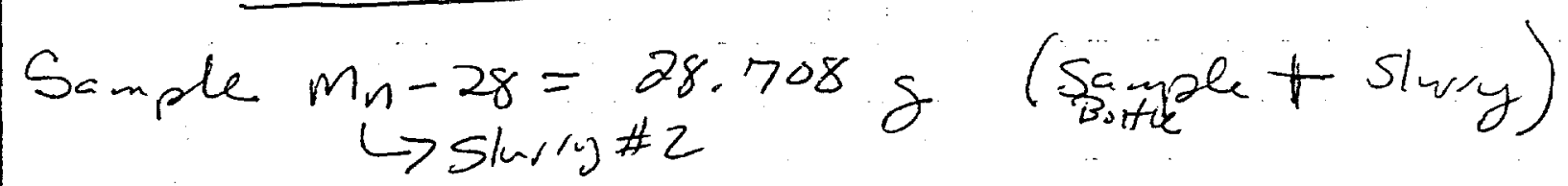

$14: 01$
$201 \mathrm{pm})$ Stating tot 4- 55psig 3.10-3.16 8p?

$\sim 14: 30$. Flusted samplins systan

$14: 5^{\circ}$ took filtrate sample $=m_{1-29}=27.037 \mathrm{~g}$ (scikele

1511 Finished Condition 4

Back pulsoing 4 tims.

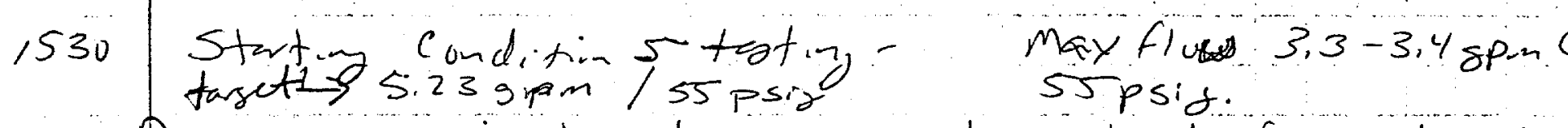

Ar pressurc is to lou to achive hidh flouretese Having buiddio Arr. cheilul-

1601 - Re stating Conditin 5 with a new tarif of 2i.25 gpm $\beta$ SSpsig.

Back pulsed 3 times before stut

Putting in two more sorple bottles

$$
\begin{aligned}
& m_{n 31}-\operatorname{tar}=16.8608 \\
& m_{n 32}=16.9707
\end{aligned}
$$

$4: 44$

Sample $M_{n}-30=33.347 \mathrm{~g}$ (sample botte \& sluriy)

Finish Conditon 5 - Buk pulsin 3 timos

$5: 23$ Start condition 6. $23.5 \mathrm{gpm} / 55 \mathrm{psig}$

Sample $m_{n}-31 \rightarrow$ Filtate $27.244 \mathrm{~g}$ (sample bottle bsluing)

$6: 25$ Finished conditun 6

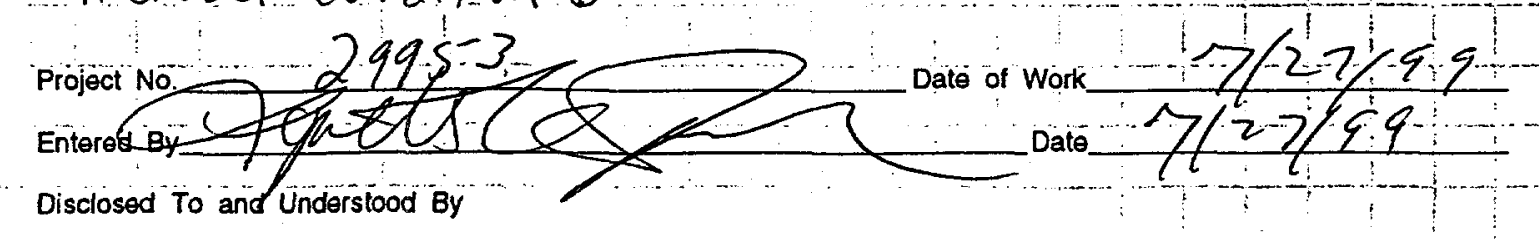


7:05 pm Drained - $850 \mathrm{ml}$ of AN-109 Archive Recouped 7:30 Added IL .2M NaH pumped a rued r 15 min. While pumping allowed to go trough filtrate System 5 min - open and closed V6 3 times to rinse glass flow meter (filed to toptounllow) Then Back pulsed 3 times.

7:53 Draining - Collecting into bottle labeled 1 strange 8:14 Refilled with $1.5 \mathrm{~L} \mathrm{H}_{2} \mathrm{O}$, Running e 50 psid 24.5 gpmance trying to poise tank wats with thesaspatter Bather distal them,

8:25 Drained -

Refilled with 2 L DI $H_{2} \mathrm{O}-$ Ran $15 \mathrm{~min}$. 9:05 pm Shut down

$8 / 99$ 8: $\$ 0$ am Turned on Cur at 30 psi a 4.5 gp 8.30 an Back pulsed \&d drained

8:49 am Aaddedlignid w/ tube to backpulse chamber Performed $S$ times

9:50 am Folded 1.SL DI water into system and ran around for a while at 30 psi \& Sam Rinsed filtrate sample line $\$$ upper loop

10:30 Drained -

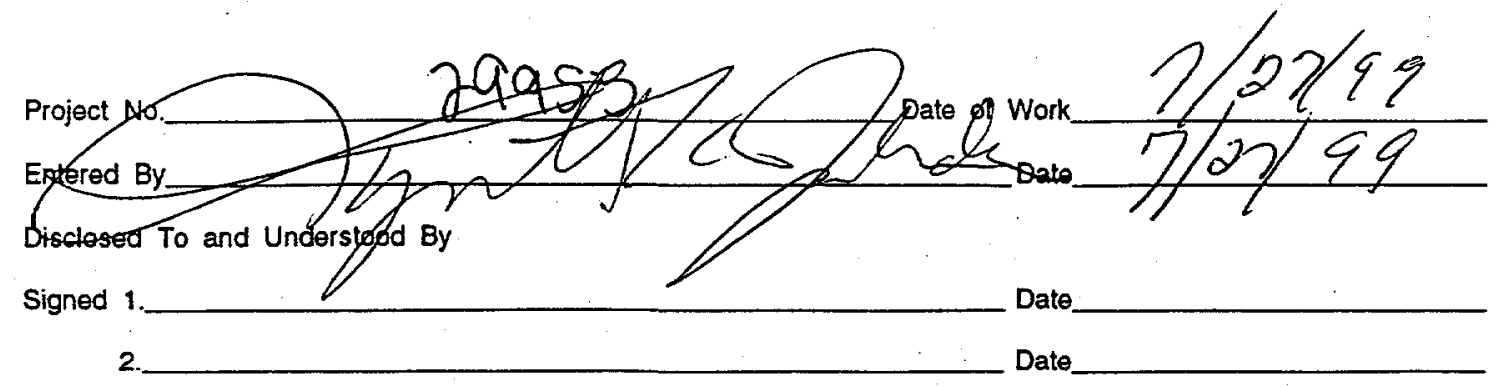


AN-107 Archive - Composite prep.

$1128 / 99$ Preparation of composite $m-32$ (tic 16.970

11:31 am tared total wt sample only \#got indie

After $2 \mathrm{ml} \quad \overline{m_{n}}-24 \quad 2.377 \mathrm{~g}$ total After $\sim 2 \mathrm{ml} m_{n}-254.789 \mathrm{~g}$ total Aftertime $m_{n}-26 \frac{1518}{6}+192 \mathrm{gtotal}$ After $\sim 2 \mathrm{ml} m_{n}-299.543 \mathrm{~g}$ total After $\sim 2 \mathrm{ml} m_{n}-3012.076 \mathrm{~g}$ total After $\sim 2 \mathrm{ml} m_{n}-3114.2118 \mathrm{~g}$ total $1 \mathrm{~g}$ check $\frac{2.342 \mathrm{~g} 1}{14.418 \mathrm{~g}}$

2.3778

$2.412 g_{1}$

$2.403 \mathrm{~g}$
$.351 \mathrm{~g}$
$.533 \mathrm{~g}$
$.342 \mathrm{gr}$
$.4188^{6}$

Total wt. Bute plus composite sash $=31.386 \mathrm{~g}$

1-2:30 Tranferd samples out to soto SAL for ara Samples transfer. TCTx-ol $m_{n}-32 \quad m_{n} 23$ $T_{C} T_{x}-02 m_{n} 21 \quad m_{n 28}$ $m_{n}-31 \quad m_{n} 22 \quad m n 27$

2:45 Refilled with $11.5 \mathrm{~L} \mathrm{H}_{2} \mathrm{O}=$ ran $\sim 30 \mathrm{~min}$ 3!20 Brushed down sides - water now fang \$ bro

3:40 Took pit - $\cong 7,5$ or less - $\therefore$ Can attach filth now.

4:00 Shat down until fomosom 
199

AN-ル

Archive

9:00km - up and running to re rix susspend, solids in systim.

10ila Itoolud yo \$ ruming 0.05 in filter system, 25 psig; - $4.8 \mathrm{gpm}$ - Very Foamy a Cloudy 10is's Packpulsing with Clean to to from the

2:00 Cleaned until 12:00 still a little clondy

1,45 Continued to clader unt.1 lit,5-

cujstal clear visually- Pvi \& viv clusal.

$\because 55 .-$ Testing - 20 psid $\% 4.2 \mathrm{gpm}$

$$
\begin{array}{ll}
T=0 & R=20-21\rangle \\
T=8.5 & R=17
\end{array}
$$

2:05 v4 off-Buk pulsing 10 timas

$2: 29$ Cleasing again - $\$ 2$ \$ 10 open to 0.05 in filter

2.50 Pulsed flow 6-.7 tims to create tubahu/diffent fliow patters.

$3: 15$ - Partialy draned (putf filtin dic harge into wastecintina) Retillud with $2<$ all addent from the top as Clean $\mathrm{H}_{2} \mathrm{O}$ back palsez.

$3: 45$ - Runniy again- Hzo brownish \& clindy.

$4 ! 23$ - buildig air diwn - pump shut off

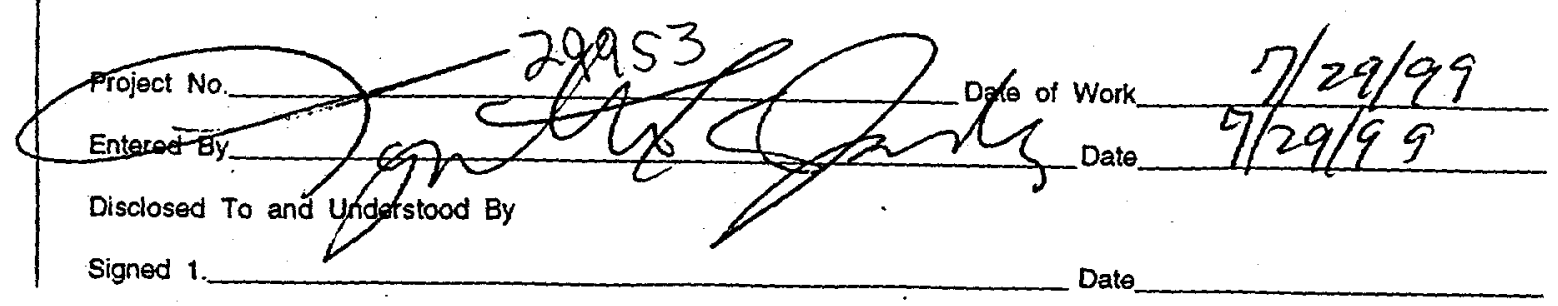

Date 
AN-107 clenrup.

6.

$7 / 3.499$

7:50 Systimup prunning - Uz Bvid open if filkng

$8: 55$ looks clear visully-VLB URo clused-

get conditions to 20 psiz $24.2 .8 \mathrm{pm}$. opm U4 - readjust to $20 / 4.2$ opn

$$
\begin{array}{ll}
T=0 & R=22.5 \\
T=6 & R=20 \\
T=10 & R=20 \\
T=14 & R=20 \\
T=17 & R=18 \\
T=20 & R=17.5
\end{array}
$$

9:23 - Testing shows systim is still not clim =

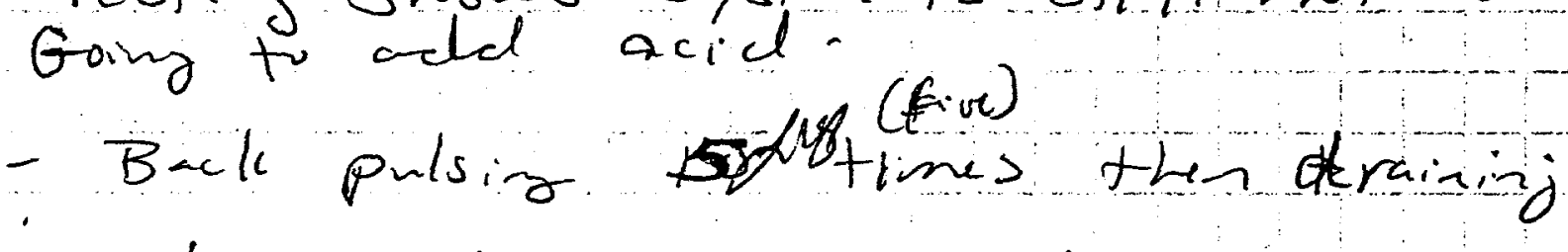

9:24 - Back pulsing butimes then derain

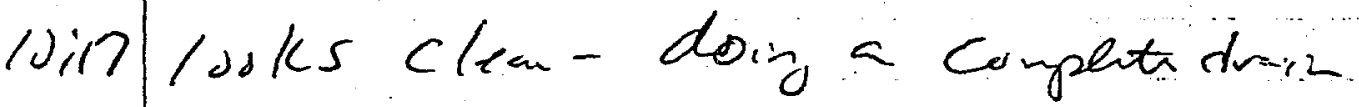

10.39 Pouring Acid in - twrough top. CIL MAHNu 0.2 Mathe 11:20 running acid-25psiz-4ilgpm (pulindafuction 12.46 - Runflarid Finisted - Mry foany12:48 Drainung - Acid greensh now OTQ i:25 Refind Clen Ho - vunniz. (30psig r 45 ga) OPA V4 3 timi - R perz e $60+18$ tills fist.

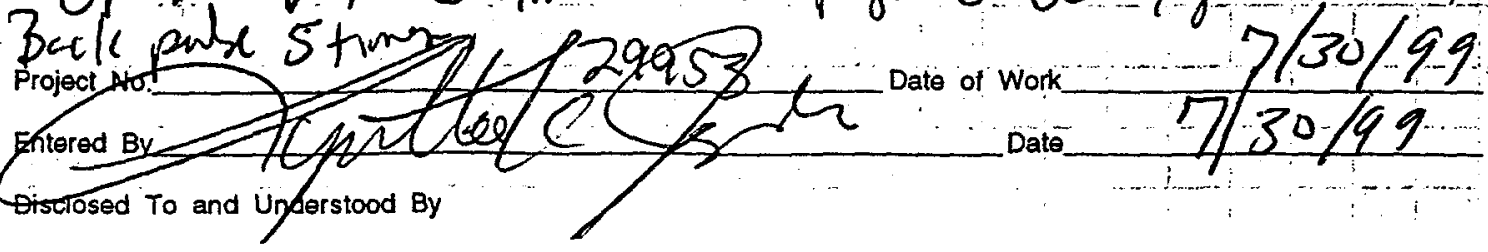


risy Draining:

1:40 * Note - Leak detected in the Backpulsechamber @bottom of Site glass.

2:00 Refilled andrunniz a 30 psir $\sim 4$.

2:13 Stopper/ Draining

$$
\begin{aligned}
& 2: 20 \text { Refilled - Ran- } \\
& 2: 45 \text { Draind } \\
& : \quad \text { PH }=-3-3.5
\end{aligned}
$$

2:55 Refillot funning $p H=3,5-4.0$

$$
\begin{aligned}
& 3: 20 \\
& 3: 30 \\
& \text { 3i46 } P H=4.51 .
\end{aligned}
$$

Shuttry down -
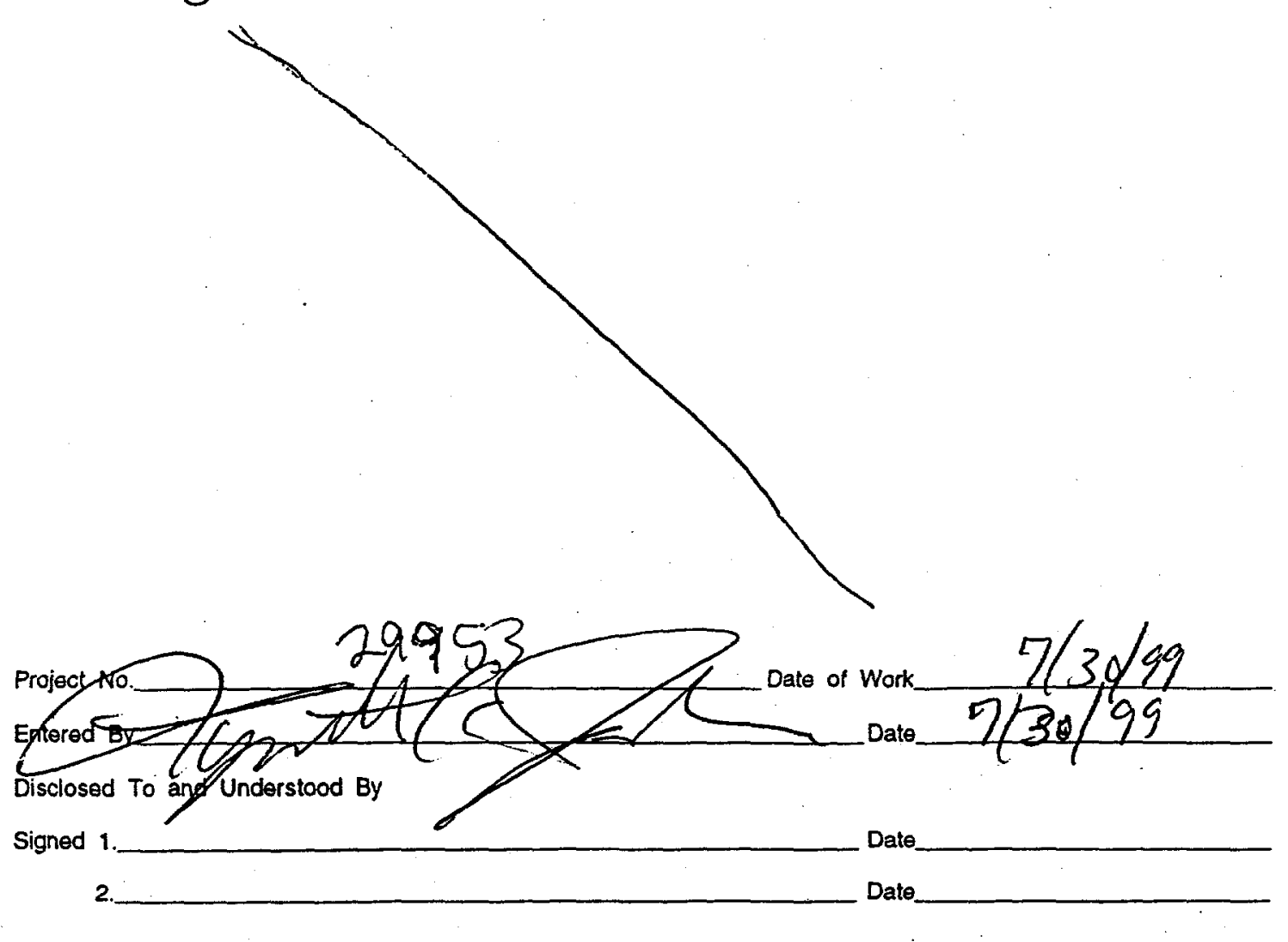
Appendix B: Test Instruction-063 and Log Book Entries

Sr/TRU Removal from Archived AN-107 with Minimal Reagent Addition

Log Book Entries 
TI-29953-063, Rev. 0

Page 1 of 8

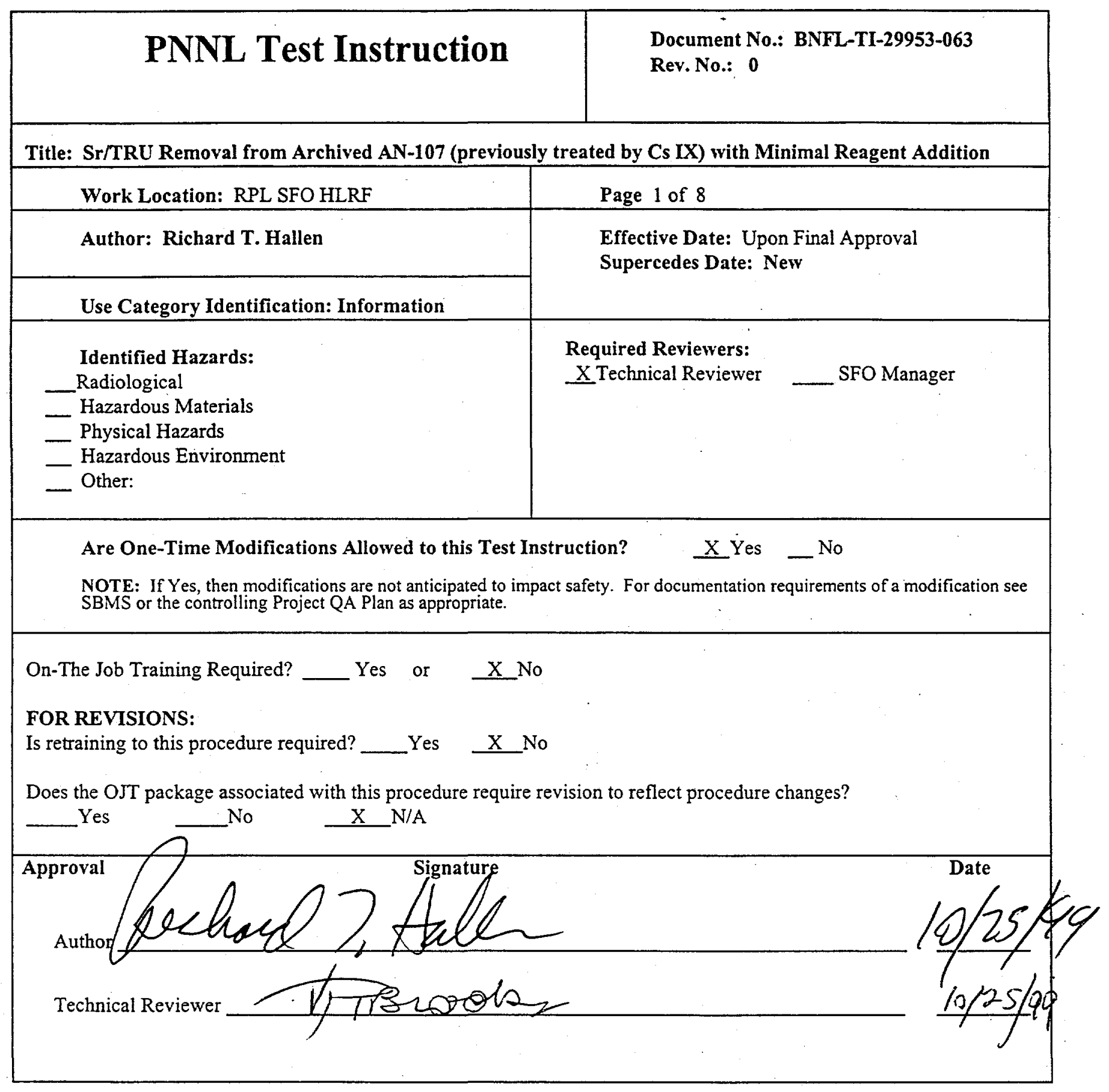




\subsection{Applicability}

This test instruction is to be used to perform studies on permanganate treatment for Sr/TRU removal from archived $\mathrm{AN}-107$ waste that has been previously treated by cesium ion exchange resin and prepare addition treated waste for sulfate removal studies. The precipitation will be conducted in SAL and solids removed by deadend filtration.

Approximately 1-L of AN-107 waste (use C3E4 first then C3E5, and/or C3E6) will be used.

\subsection{Supporting Documents}

This test instruction is a stand-alone document. Background information on permanganate treatment can be found in PNNL Test Plan BNFL-TP-29953-013, which contains an overall description of the project, ES\&H compliance, emergency response, and the hazards assessment and mitigation. Past scoping tests on the permanganate treatment of AN107(cesium removed) are described in detail in test instructions, TI-29953-037, -040, -041, and -043 .

\subsection{Responsible Staff}

The staff responsible for executing this test plan are as follows.

- Task Manager - Dean Kurath

- SFO Manager - Rick Steele

- Test Scientists/Engineers - Kriston Brooks and Rich Hallen

- Hot Cell Technician - Vaughn Hoopes

- Radiological Control Technician

\subsection{Materials, Equipment, Supplies and Reagents Needed}

\subsection{Materials Required}

1. Four $20 \mathrm{~mL}$ glass scintillation vials for samples, pre-labeled on top and side as follows: MR-01 - MR-04.

- 2. One $250 \mathrm{~mL}$ filtrate Storage Bottle.

3. 1-L size disposable filtration unit, 0.45 um filter.

-4. 150 -mL disposable filtration unit, 0.45 um filter.

$\checkmark$. One $150 \mathrm{~mL}$ breaker or bottle for transferring and weighing the Archived AN-107 iaso ine Piastic beake $T=147621$

\subsection{Equipment}

-1. 160 gram balance (largest available in SAL)

-2. Calculator

3. 2-L erlenmeyer flask

4. hot-stir plate

5. Thermometer or thermocouple/reader

6. big stir bar

7 . watch

1.8. Catch pan to use as secondary containment. 


\subsection{Reagents Needed}

1. $48 \mathrm{~mL}$ of $19 \mathrm{M}(50 \mathrm{wt} \%) \mathrm{NaOH}$

2. $57 \mathrm{~mL}$ of $1.0 \mathrm{M} \mathrm{Sr}(\mathrm{NO} 3) 2$

3. $34.2 \mathrm{~mL}$ of $1.0 \mathrm{M} \mathrm{NaMnO} 4$

4. 1 liter of Archive AN-107 - 甘4

4.4 Other Supplies

345

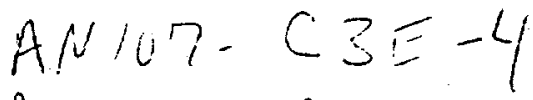

ANiLn-CSE-S

1. Control Copy of this Test Instruction

$\sqrt{2}$. Laboratory Record Book (record LRB\# 13733)

\subsection{Test Instructions for Permanganate Treatment}

The laboratory record book (LRB) shall be used to record other testing information as required by this procedure and all test conditions not stated by this procedure.

Cross-contamination between samples and contamination of samples from outside sources must be minimized at each step. Use new supplies and bottles for each sample as much as possible.

Keep all test materials in sealed containers as much as possible to prevent them from drying.

\subsection{Pre-start}

5.1.1. Inventory materials, equipment, supplies, and reagents to ensure all required items are available. Assure that all materials have been modified for remote handling. (The large Erlenmeyer flask will need to be banded so the waste can be poured out. The 1-liter filter flask is large and hard to handle in the cell, band the flask.)

5.1.2 Do the following and initial and date when completed.

$10 / \frac{2}{R}$ eview the work instructions in this TI.

5.1.3 Record the weights of all the materials/supplies before they are transferred into the hot cell.

Sample vials $\begin{array}{ccc}\underline{\text { ID\# }} & \frac{\text { Empty }}{16.8154} \mathrm{~g} & \frac{\text { Full }}{42.9240} \mathrm{~g} \\ \text { MR-02 } & \frac{16.8161}{\mathrm{MR}-03} \mathrm{~g} & \frac{17.0376}{16.9364 \mathrm{~g}} \\ \text { MR-04 } & 16.8920 \mathrm{~g} & \end{array}$

Stir Bar $\quad 38.4447 \mathrm{~g}$ Erlenmeyer Flask $736 \mathrm{~g}$

Large

Filter unit receiver $\frac{571}{85.1503} \mathrm{~g}$ cap $\frac{15.2208}{18.8575} \mathrm{~g}$
Filter unit

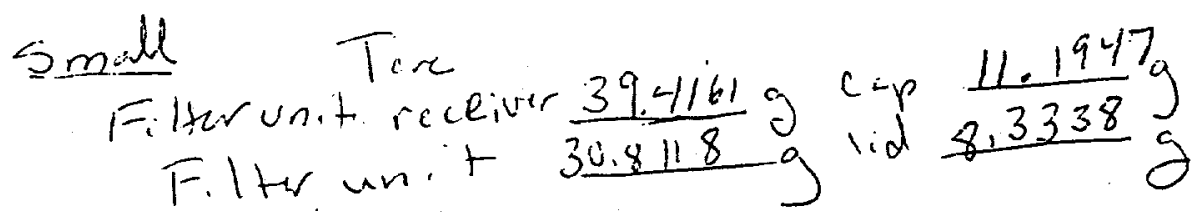


Filtrate storage bottle $587 \mathrm{~g} \mathrm{w} / \mathrm{i}$ id

\subsection{Start-Up}

5.2.1 Obtain the following information:

M\&TE List:

Balance 1 a - (antside of cell) (160g)

Balance 1:

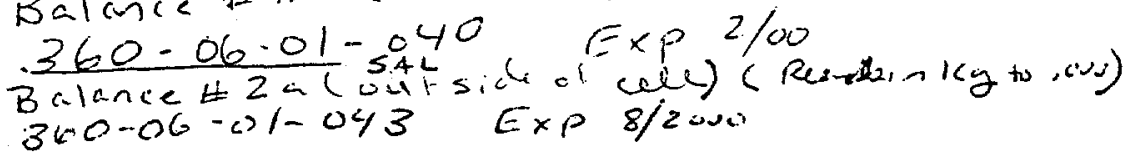

Calib ID

Location SAL Cell 2

Thermocouple or Thermometer: TC-325-415

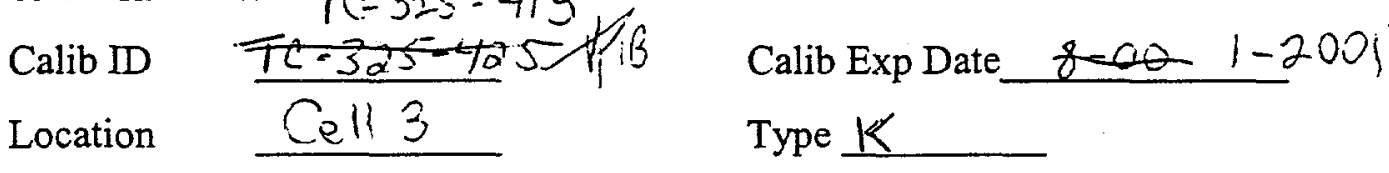

5.2.2 Record the identification number on the bottle of archived AN-107 (verify/identify sample is AN-107 id\#).

Bottle Label(s) $\frac{A N^{\prime} \cdot 107-C 3 E-4}{A N^{\prime}-107-C 3 E-5}$

\subsection{Sr/TRU Removal by Permanganate Treatment}

5.3.1 Setup the ppt reaction equipment as specified. The precipitation is to be conducted in a $2 \mathrm{~L}$ flask. Secondary containment should be used to allow recovery from a possible breach of the $2 \mathrm{~L}$ flask. Place stir bar in flask.

Add $1000 \mathrm{~mL}$ of archived AN-107 to the Erlenmeyer Flask. Because the balance will only measure 160 grams, 10 transfers should be completed, each with approximately $100 \mathrm{~mL}$ of waste.

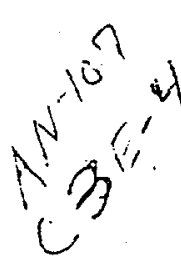

Tare weight bottle

$14.76 .21 \mathrm{~g}$

now add another $100 \mathrm{~mL} *$ now add another $100 \mathrm{~mL}$ now add another $100 \mathrm{~mL}$ now add another $100 \mathrm{~mL}$ now add another $100 \mathrm{~mL}$<smiles>c1cscn1</smiles>
now add another $100 \mathrm{~mL}$ now add another $100 \mathrm{~mL}$ now add another $100 \mathrm{~mL}$ now add another $100 \mathrm{~mL}$

Add $\sim 100 \mathrm{~mL}$ $138.8350 \mathrm{~g}$

$132,3573 \mathrm{~g}$

$125.9800 \mathrm{~g}$

$129,9138 \mathrm{~g}$

$131.0341 \mathrm{~g}$ $123.1172 \mathrm{~g}$ $131.3619 \mathrm{~g}$ $129.4123 \mathrm{~g}$ $137,0690 \mathrm{~g}$ $131.0906 \mathrm{~g}$

\section{After Waste}

Pour in Flask

$14.9370 \mathrm{~g}$ transfer $1=12.3 .8780 \mathrm{~g}$

$14.9057 \mathrm{~g}$ transfer $2=117.41516 \mathrm{~g}$

$15.0023 \mathrm{~g}$ transfer $3=110.9777 \mathrm{~g}$

$14.9302 \mathrm{~g}$ transfer $4=114,9336 \mathrm{~g}$

$15.0090 \mathrm{~g}$ transfer $5=116.0251 \mathrm{~g}$

$14.966 .4 \mathrm{~g}$ transfer $6=108.1508 \mathrm{~g}$

is $15.0333 \mathrm{~g}$

$0 / 1+\frac{14.9678}{14962}$

$14,9162 \mathrm{~g}$

i5.0100 $\mathrm{g}$

transfer $7=416,3289 \mathrm{~g}$

transfer $8=114.8445$

transfer $9=122.152 \%$

transfer $10=116.0806 \mathrm{~g}$

Total $=1,160,8736 \mathrm{~g}$

fon the $8^{\text {th }}$ addition more sample was added to to the cup before weighing so an aug. of the other nime wts was used. 
Density $=$ $\mathrm{g} / \mathrm{mL}$ Total volume $=$ Total $\mathrm{mass} /$ density $=$ $\mathrm{mL}$

Turn on stirrer. Turn on the temperature recording devise. Record temperatures of cell and

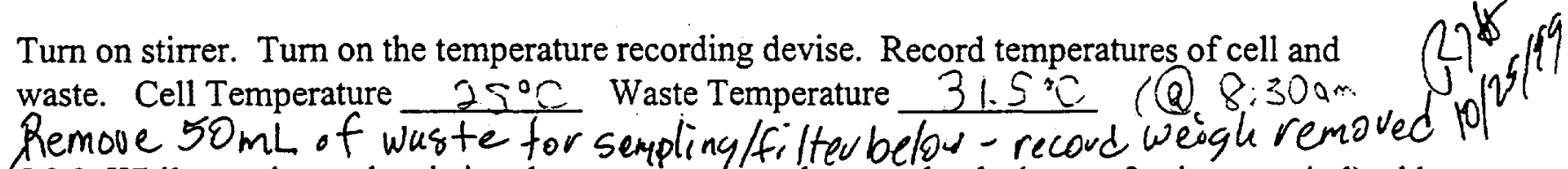
5.3.2 While continuously stirring the waste, personnel are to slowly (over a 2 minute period) add $48 \mathrm{~mL}$ of $19 \mathrm{M}(50 \mathrm{wt} \%) \mathrm{NaOH}$. This is the entire content of the bottle labeled $19 \mathrm{M} \mathrm{NaOH}$.

Tare bottle of $19 \mathrm{M} \mathrm{NaOH} 98.0334$ (w+outsich f cell)

Tare Empty bottle

Weight Added

7

6:53 Added
gier 3 mintes

5.3.3 While continuously stirring the waste, personnel are to slowly (over a 5 minute period) add $57 \mathrm{~mL}$ of $1.0 \mathrm{M} \mathrm{Sr}\left(\mathrm{NO}_{3}\right)_{2}$. This is the entire content of the bottle labeled $1 \mathrm{M} \mathrm{Sr}$.

Tare bottle of $1 \mathrm{M} \mathrm{Sr} 91.3135$ (wt. 0-tsicle of celi)

Tare Empty bottle

Weight Added

$\frac{2 \hat{2} \cdot \hat{\sigma} 641}{6.0494}$

$6: 12-6: 18 \mathrm{am}$

frdded jr

5.3.4 While stirring, slowly (over a 5 minute period) add $34.2 \mathrm{~mL}$ of $1 \mathrm{M} \mathrm{NaMnO}_{4}$. This is the entire content of the bottle labeled $1 \mathrm{M} \mathrm{NaMnO} 4$

Tare bottle of $1 \mathrm{M} \mathrm{NaMnO} 497.2778$ (unt. outside of (ell)

Tare Empty bottle 57.9487

$7.27 \quad 5 \% a, 4$

Weight Added

3932919

$7: \overline{3}$ complete.

5.3.5 Allow the waste to thoroughly mix after addition of all of the reagents, i.e. stir for 30 minutes.

Begin heatig 8:2,2 an

5.3.6 Heat the waste mixture at $50 \pm 5^{\circ} \mathrm{C}$ with stirring for 4 hours. Record temperature.
Staticd 4 hirs 8,33 am $-45^{\circ} \mathrm{C}$ dollect above $-50 \mathrm{C}$

$>$ While the waste is digesting for 4 hours, transfer 20 -mL of waste the vial MR-01 and record the weight of sample. This sample will be the unfiltered control, and is to be digested with acid as is for analytical. Duplicate samples need to be digested and submitted for analyses. Then filter approximately $30 \mathrm{~mL}$ of the original waste with $0.45 \mathrm{um}$ filter. Use the filtrate to determine the density of the Archived AN-107 in duplicate using volumetric flasks (use $10 \mathrm{~mL}$ ball flask)

Tare flask 14.2162 Flask plus $10 \mathrm{~mL}$ of waste Weight of $10 \mathrm{~mL}$ of waste

Tare flask 9.3997 Flask plus $10 \mathrm{~mL}$ of waste
(1)

$\frac{26.8939}{12.6297}$

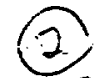
22.078 density of waste $1.268 \mathrm{~g} / \mathrm{mL}$

6.5159 
Transfer $20 \mathrm{~mL}$ of the filtrate to vial MR-02 and record the weight. This sample is the filtered control. Sample in duplicate, acid digest, and submit for analyses.

12.41 pin-stierier and heatr of

5.3.7 After 4 hours of digesting, turn off the stirrer and allow the waste to cool to $25 \pm 5^{\circ} \mathrm{C}$. If possible, use a video recorder to document the settling behavior of the waste mixture. Record the volume of settled solids if possible. $\mathrm{mL}$ See video-mayke $100 \mathrm{ml}$ deir siper:

\subsection{Solids Removal with the Deadend Filter Unit}

5.4.1 Tare the 1-L receiver bottle/lid and filter assembly/lid of the filtration unit (preferably before it is sent into the cell). Make sure receiver bottle is banded for remote handling.

Tare of receiver bottle _ $\quad$ and lid $586 \mathrm{~g}$ Tare of the filter assembly 104,2824 and lid A with lid see section 51 this instrection.

5.4.2 Assemble 1-L filtration unit and filter all of treated waste in the erlenmeyer flask Some solids should have settled on cooling/setting. Decant most of the supernate from the flask to the filter. The supernate should filter faster without all of the solids/cake on the filter unit. When approximately half the material has been filtered, swirl the bottle to suspend the solids. Continue filtering the slurry. If excessive solids remain in the bottom of the bottle, small amounts of filtrate can be used to rinse the solids from the bottle. Record weight of empty flask if possible. Filter the solids until compacted on filter and no free liquid remains. Disassemble filter unit and weigh. If necessary to get filtrate to Sandy Fiskum by $\mathrm{COB}$ Wednesday, stop filtration and transfer $250 \mathrm{~mL}$ of waste to a tared, $250 \mathrm{~mL}$ storage bottle. $\frac{\text { Done inst }}{\text { Tare of }}$

Tare of the filter assembly/lid and wet solids

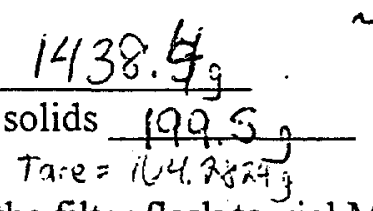

$$
\begin{aligned}
& 700 \mathrm{~mL} \\
& \text { Weight of filtrate } \frac{587 \mathrm{~g} \text { tare }}{2}=851.4 \\
& \text { Weight of wet solids } 95.217 \mathrm{~g} \text {. } \\
& =56.7729 \mathrm{stir}
\end{aligned}
$$

5.4.3 Transfer $20-\mathrm{mL}$ of filtrate from the filter flask to vial MR-03. Determine the density of the filtrate in duplicate using volumetric flasks (use at least $10 \mathrm{~mL}$ ball flask, prefer $25 \mathrm{~mL}$.)

Tare flask 19.90815

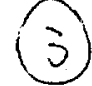

Flask plus $25 \mathrm{~mL}$ of filtrate

Weight of $25 \mathrm{~mL}$ filtrate $\operatorname{sij} 3483$

Tare flask 20.3640 (4)

Flask plus $25 \mathrm{~mL}$ of filtrate 51,0622

Weight of $25 \mathrm{~mL}$ filtrate 31.4403 density of filtrate $12576 \mathrm{~g} / \mathrm{mL}$

Transfer the remaining treated, archived AN-107 filtrate to the sample storage bottle. Collect the solids on the filter and save for future work.

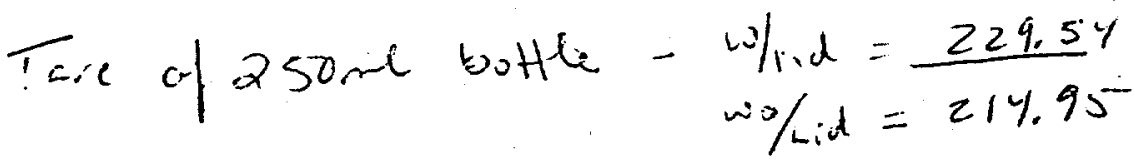
density of filtrate $1.2599 \mathrm{~g} / \mathrm{mL}$ 


\subsection{Experimental Clean Up and Sample Disposition.}

Clean up all of the equipment used.

Do not discard any samples without written instructions from the task manager. Duplicate samples were collected at all sampling points. The duplicates are to be retained until review of the analytical data is completed and notification is writing is received to dispose of these samples.

\subsection{Sample Analysis}

The point of contact for the sample analysis is Mike Urie and Rick Steele.

Prepare and submit all samples in duplicate. Analyze all samples for the following: Am/Eu by GEA, Sr-90 analysis, Tc-99 beta scintillation without oxidation, and $\mathrm{Na}$ by ICP-AES (report all detected analytes).

Table 1. Samples and Their Required Analyses

\begin{tabular}{|l|c|c|c|c|}
\hline \multicolumn{1}{|c|}{ Process Variable } & $\begin{array}{c}\text { Vial } \\
\text { ID }\end{array}$ & Sample Type & Sample Preparation & Analysis Description $^{(a)}$ \\
\hline Archived AN-107 & MR-01 & as received & acid digest & $\mathrm{Am} / \mathrm{Eu} / \mathrm{Sr} / \mathrm{Tc}, \mathrm{Na}$ \\
\hline Archived AN-107 & $\mathrm{MN}-02$ & as received & $0.45 \mathrm{um}$ filter, acid digest & $\mathrm{Am} / \mathrm{Eu} / \mathrm{Sr} / \mathrm{Tc}, \mathrm{Na}$ \\
\hline Treated AN-107 & $\mathrm{MN}-03$ & filtrate & acid digest & $\mathrm{Am} / \mathrm{Eu} / \mathrm{Sr} / \mathrm{Tc}, \mathrm{Na}$ \\
\hline
\end{tabular}

(a) Descriptions of analyses are contained in Table 2.

Table 2. Description of Analyses

\begin{tabular}{|l|l|l|}
\hline \multicolumn{1}{|c|}{ Constituent } & \multicolumn{1}{|c|}{ Analysis Method } & \multicolumn{1}{c|}{ PNNL Procedure No. } \\
\hline Americium-241, Eu isotopes & GEA & PNL-ALO-450 \\
\hline Strontium-90 (Yttrium-90) & Separations and Beta Counting & PNL-ALO-476/431 \\
\hline Tc-99 & $\begin{array}{l}\text { Beta Counting without chemical } \\
\text { oxidation }\end{array}$ & \\
\hline Metal Ions (see Table 5 list) & ICP-AES & PNL-ALO-211/280 \\
\hline
\end{tabular}


Table 3. Analytical Requirements for Supernate/Filtrate

\begin{tabular}{|c|c|c|}
\hline Analyte & $\begin{array}{c}\text { Supernate/Filtrate } \\
\text { Minimum Reportable } \\
\text { Quantity microCi/gm }\end{array}$ & Analysis Method \\
\hline Americium-241 & $1 \mathrm{E}-03$ & GEA \\
\hline Europium-154 & $1 \mathrm{E}-03$ & $\overline{\text { GEA }}$ \\
\hline Europium-155 & $1 E-03$ & $\overline{\text { GEA }}$ \\
\hline Strontium-90 & $1 \mathrm{E}-01$ & $\begin{array}{c}\text { Chemical Separation \& Beta } \\
\text { Count }\end{array}$ \\
\hline Technetium-99 & $1 E-02$ & $\begin{array}{l}\text { Beta Scintillation without } \\
\text { sample oxidation }\end{array}$ \\
\hline & microgm/gm & \\
\hline$\overline{\mathrm{Al}}$ & NR & \multirow{21}{*}{$\begin{array}{l}\text { Acid Digestion followed by } \\
\text { ICP-AES }\end{array}$} \\
\hline$\overline{\mathrm{Ba}}$ & NR & \\
\hline $\mathrm{Ca}$ & NR & \\
\hline $\mathrm{Cd}$ & NR & \\
\hline$\overline{\mathrm{Co}}$ & NR & \\
\hline $\mathrm{Cr}$ & $\mathrm{NR}$ & \\
\hline $\mathrm{Cu}$ & NR & \\
\hline$\overline{\mathrm{Eu}}$ & NR & \\
\hline$\overline{\mathrm{Fe}}$ & $\mathrm{NR}$ & \\
\hline $\mathrm{K}$ & NR & \\
\hline$\overline{L a}$ & NR & \\
\hline $\mathrm{Mg}$ & NR & \\
\hline $\mathrm{Mn}$ & NR & \\
\hline Mo & NR & \\
\hline $\mathrm{Na}$ & $2.3 E+05$ & \\
\hline$\overline{\mathrm{Ni}}$ & NR & \\
\hline$\overline{\mathrm{Pb}}$ & $\overline{N R}$ & \\
\hline $\mathrm{Si}$ & NR & \\
\hline $\mathrm{Sr}$ & NR & \\
\hline$\overline{\mathrm{Ti}}$ & NR & \\
\hline $\mathrm{U}$ & $\overline{\mathrm{NR}}$ & \\
\hline$\overline{Z n}$ & NR & \\
\hline
\end{tabular}

$\mathrm{NR}$ no minimum reportable quantity but report data for all analytes detected 
Treatment of Archived AN-107 with minimal reagent additi double per Mike Johnson

$$
\text { to }
$$$$
\begin{array}{lll}
1 \mathrm{M} \mathrm{Sr} & 0.0285 \text { Liter } & \text { or } \\
1 \mathrm{M} \mathrm{MnO} 4 & 0.0171 \text { Liter } & \text { or }
\end{array}
$$

or.

or

or
0.912 moles

0.057 moles

0.0342 moles

Balance number: $\frac{380-06-01-0 / 3}{2 / 00}$

Makeup $50 \% \mathrm{NaOH}$ solution $-19 \quad \mathrm{M}$ use $\mathrm{NaOH}$ pellets

40 grams/mole (FW) (lot \# $1012 E G$ ) ACS reagent $-97+0 / 0$

Tare

add $\quad 36.48$ grams $\mathrm{NaOH}$

24.8879 grams

add $\quad 36.48 \mathrm{~g}$ water 91.9663 grams

actual weight of $\mathrm{NaOH}$ added

grams

actual weight of water added

grams

Label bottle with ID, $50 \% \mathrm{NaOH}$ total eight $98.0319 \mathrm{gram}$

Makeup $\mathrm{Sr}(\mathrm{NO} 3) 2$ solution $48 \mathrm{ml}$

use $\mathrm{Sr}(\mathrm{NO} 3) 2$

211.63 grams/mole (FW) (lot \#

Tare

add $100 \mathrm{~mL}$ bottle

$\frac{21.9174 \text { grams }}{\text { bottle }+\operatorname{Sr}(\mathrm{NO}) 2} \frac{33.9904 \text { grams }}{91.3185 \text { gram }}$

12.0629 grams $\mathrm{Sr}(\mathrm{NO}) 2$

add

$57 \mathrm{~g}$ of water $\% 1.3185$ grams

actual weight of $\mathrm{Sr}(\mathrm{NO} 3) 2$ added

actual weight of water added

grams

Label bottle with ID, IM Sr $\left(\mathrm{NO}_{3}\right)_{2} 57 \mathrm{~mL} 91.319 / \mathrm{grame}$

grams

Makeup NaMnO4 solution

use $\mathrm{NaMnO} 4 . \mathrm{H} 2 \mathrm{O}$

159.94 grams/mole (FW) (lot \#

Tare

$100 \mathrm{~mL}$ bottle

add

5.46995 grams NaMnO4

add

57.6883 grams

bottle + NaMnO4 63.1533 grams

$34.217 .1 \mathrm{~g}$ of wat 97.2223 grams

actual weight of $\mathrm{KMnO} 4$ added

actual weight of water added

grams

Date prepared: $10 / 25 / 95$

Prepared by:

$1 \mathrm{MNaMnO}_{4}$

grams

Work Package Number:

$$
453400 \quad 34.2 \mathrm{~mL}
$$

$97.2792 \mathrm{~g}$

W53400

Copy 
RECEIVED

OCT 251999

EUGENE V. Wi rRREY
River Protection Project Waste Treatment Plant

3000 Ceorge Washington Way Richland, WA 99352

Tel: (509) $371-3500$

Fax: (509) $371-3504$
Mr. Eugene Morrey

Pacific Northwest National Laboratory

P.O. Box 999, MSIN P7-28

Richland. Washington 99352

Dear Eugene:
Direct tel: $509-376-1982$

Direct fax: $509-376-7127$

CCN\#: $\quad 007525$

OCT 211999

\section{Contract No. DE-AC06-96RL13308 - W375 - PREPARATION OF ADDITIONAL ARCHIVED AN-107 SOLUTION FOR SULFATE SEPARATION TESTS}

References:

1. Document, BNFL-TI-29953-061, revision 0, "Sulfate Removal Studies from AN107 Aichived Waste," Battelle Pacific Northwest Division, Riclland, Washington, dated October 18, 1999.

2. CCN\# 004960, M. E. Johnson, BNFL Inc. to E. V. Morrey, Battelle, "Conditions for Precipitation of Sr/TRU in Archived 241-AN-107 Sample," Battelle, dated July 28, 1999.

This letter specifies conditions for conducting Sr/TRU precipitation with $\sim 500$-ml of archived AN-107 solution that has previously been treated to separate cesium using crystalline silicotitanate. BNFL Inc. is requesting Battelle prepare the pretreated archived AN-107 solution for use in additional sulfate removal tests.

Battelle is conducting tests with the archived AN-107 solution to evaluate methods for separating sulfate from Envelope C waste solutions (ref. 1). The archived AN-107 solution had previously been processed through a column that contained crystalline silico-titanate to separate cesium.

Battelle used a small portion of the archived AN-107 solution to demonstrate Sr/TRU separation using sodium permanganate and strontium nitrate. Battelle then used all available pretreated, archived AN-107 solution for sulfate separation tests. Battelle needs to conduct the Sr/TRU precipitate process with additional archived AN-107 solution.

Battelle personnel conducted Sr/TRU precipitation and filtration tests with the archived AN-107 solution using the following test conditions.

$>$ Starting Conditions for the archived AN-107 solution

- Na:

- Volume:

- Am-241:

- Eu-154:
$5.68 \mathrm{M}$

$881.9 \mathrm{ml}$

$0.174 \mu \mathrm{Ci} / \mathrm{gm}$

$0.232 \mu \mathrm{Ci} / \mathrm{gm}$
Density:

$1.256 \mathrm{gm} / \mathrm{ml}$

Co-60:

Eu-155:
$0.0616 \mu \mathrm{Ci} / \mathrm{gm}$

$0.166 \mu \mathrm{Ci} / \mathrm{gm}$ 
- Sr-90: $\quad 38.5 \mu \mathrm{Ci} / \mathrm{gm}$

$>$ Reagents Concentrations and Conditions

- Free hydroxide (calculated) was $0.8 \mathrm{M}$,

- Final $\mathrm{NaMnO}_{4}$ molarity was $0.05 \mathrm{M}$,

- Final $\mathrm{Sr}\left(\mathrm{NO}_{3}\right)_{2}$ molarity was $0.075 \mathrm{M}$

- Heat mixture to $50^{\circ} \mathrm{C}$ for 4-hours, then cool and filter

$>$ Final Conditions for the archived AN-107 solution before filtration

- Na: 4.83M Density: $1.226 \mathrm{gm} / \mathrm{ml}$

- Volume: $\quad 1014.53 \mathrm{ml} \quad$ Dilution factor: 1.1247 (mass basis)

- Am-241: $\quad 0.00485 \mu \mathrm{Ci} / \mathrm{gm} \quad$ Co-60: $\quad 0.0545 \mu \mathrm{Ci} / \mathrm{gm}$

- Eu-154: $\quad 0.0135 \mu \mathrm{Ci} / \mathrm{gm} \quad$ Eu-155: $\quad 0.0097 \mu \mathrm{Ci} / \mathrm{gm}$

- Sr-90: $\quad 1.52 \mu \mathrm{Ci} / \mathrm{gm}$

BNFL Inc. has selected Sr/TRU precipitation conditions different than those originally specified for the archived AN-107 sample in order to reduce the amounts of manganese hydroxide and strontium carbonate added to the high-level waste.

BNFL Inc. requests Battelle personnel to react $\sim 500-\mathrm{ml}$ of archived $\mathrm{AN}-107$ solution with sodium hydroxide, $1 \mathrm{M}$ sodium permanganate, and $1 \mathrm{M}$ strontium nitrate solutions to achieve final added concentrations of $\sim 0.8 \mathrm{M} \mathrm{OH}$ (calculated), $0.03 \mathrm{M}( \pm 5 \%) \mathrm{MnO}_{4}$, and $0.05 \mathrm{M}( \pm 5 \%) \mathrm{Sr}$. Battelle personnel are to constantly mix the slurry, heat the slurry to $50^{\circ} \mathrm{C}$ for 4 -hours, then cool and dead-end filter using a $0.45-\mu \mathrm{m}$ filter. Battelle personnel are to sample and analyze the archived AN-107 supernate before and after reagent additions to determine the supernate density, concentrations of $\mathrm{Na}, \mathrm{Sr}-90, \mathrm{Am}-241, \mathrm{Eu}-154, \mathrm{Eu}-155$, and Tc-99 by beta scintillation without sample oxidation. The minimum reportable quantities for $\mathrm{Na}, \mathrm{Sr}-90, \mathrm{Am}-241, \mathrm{Eu}-154, \mathrm{Eu}-155$, and $\mathrm{Tc}-99$ are $2.3 \mathrm{E}+05 \mu \mathrm{gm} / \mathrm{gm}, 0.1 \mu \mathrm{Ci} / \mathrm{gm}, 1 \mathrm{E}-03 \mu \mathrm{Ci} / \mathrm{gm}, 1 \mathrm{E}-03 \mu \mathrm{Ci} / \mathrm{gm}, 1 \mathrm{E}-03 \mu \mathrm{Ci} / \mathrm{gm}$, and $0.01 \mu \mathrm{Ci} / \mathrm{gm}$, respectively.

Battelle should accumulate costs for this activity as part of the sulfate removal task authorized by Mr. Bill Roberson to Ms. Whelan on October 14, 1999. A final charge control package should be submitted to BNFL Inc. for all sulfate removal tasks in November 1999.

Yours sincerely,

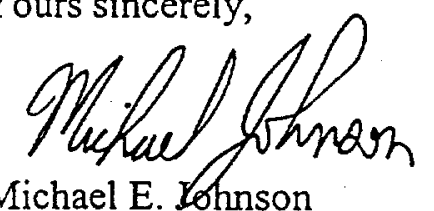

Pretreatment Technical Manager

$\mathrm{MEJ} / \mathrm{ctf}$ 
cc:

Fittro, C.T. w/o

Slaathaug, E. w/o

Johnson, M.E. w/o

$\mathrm{PDC}$ w/o
BNFL Inc.

BNFL Inc.

BNFL Inc.

BNFL Inc.
A212

E213

B268

K110 
$T(-063$

65

atment of Archived AN-107 with minimal reagent additi double per Mike Johnson page 65

500

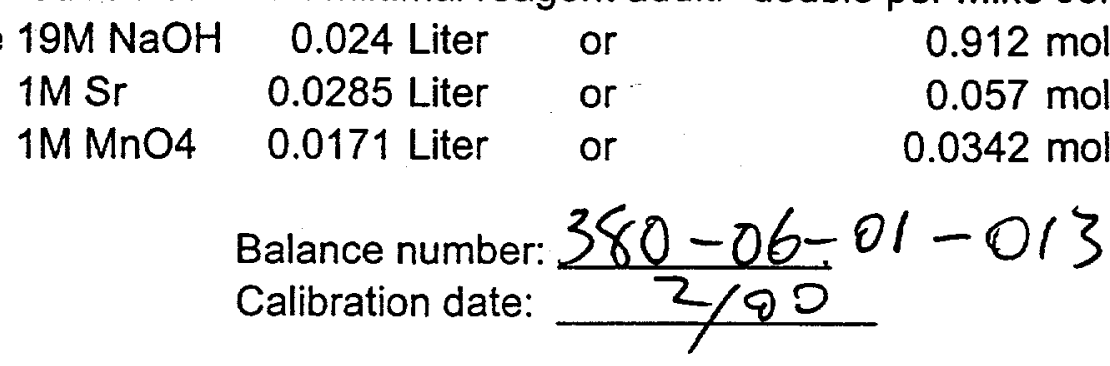

lakeup $50 \% \mathrm{NaOH}$ solution $\sim 19 \quad \mathrm{M}$ se $\mathrm{NaOH}$ pellets

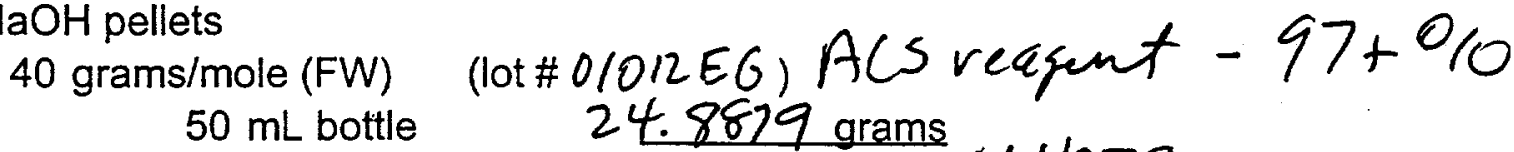

are

dd 24.8879 grams

bottle $+\mathrm{NaOH} 61.4279$ grams

add $\quad 36.48 \mathrm{~g}$ water 92.9663 grams

actual weight of $\mathrm{NaOH}$ added

grams

actual weight of water added

grams

abel bottle with ID, $50 \% \mathrm{NaOH}$ total weight $98.0319 \mathrm{gram}$

lakeup $\mathrm{Sr}(\mathrm{NO} 3) 2$ solution se $\mathrm{Sr}(\mathrm{NO} 3) 2$

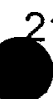

dd $48 \mathrm{mc}$

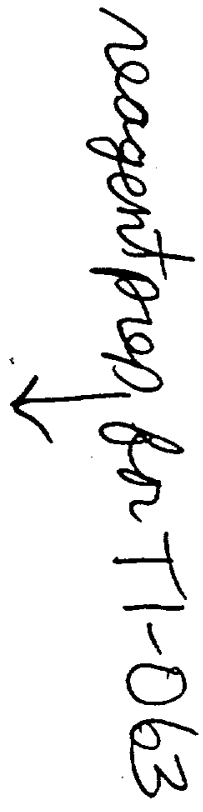

abel bottle with ID, IM Sr $\left(\mathrm{NO}_{3}\right)_{2} 57 \mathrm{~mL} 91.3191$ gram e

grams

grams

lakeup $\mathrm{NaMnO} 4$ solution

se $\mathrm{NaMnO} 4 . \mathrm{H} 2 \mathrm{O}$

159.94 grams/mole (FW) (lot \#

are

$100 \mathrm{~mL}$ bottle

dd $\quad 5.46995$ grams NaMnO4

add

57.6883 grams

bottle + NaMnO4 63.1533 grams

$34.217 .1 \mathrm{~g}$ of wat 97.2223 grams

actual weight of $\mathrm{KMnO} 4$ added

actual weight of water added

grams

grams

late prepared: $10 / 25 / 95$

$1 \mathrm{MNaMnO}^{4} 97.2792 \mathrm{~g}$

Work Package Number:

$\checkmark 53400$

$34.2 \mathrm{~mL}$

Project No Date of Work

Entered By

Disclosed To gand Understood By

Date

Simon 1 
$\hat{N}^{0^{20}} 0^{b^{3}}$

Added Il of solwion Archie. AN -10? to $1000 \mathrm{me}$ flask.

Capped o stored over night (last night)
Calibrated balance wi weights in cell

$$
\begin{aligned}
& \frac{\text { Weight of Cal. Wt }}{100 \mathrm{~g}} \frac{\text { Werigt Measured }}{100.09} \\
& \begin{array}{ll}
1000_{9} & 979.99 \\
5000_{9} & 4999.79
\end{array} \\
& \frac{6.97 / 300}{30^{2}}
\end{aligned}
$$

Wright of flask la 9s.9g (w/ rubber stopper) (61.lgans)

Adding $\operatorname{Sr}\left(\mathrm{NO}_{3}\right)_{2}$ we see white flacks in black solution increased w/ mare So addition.

Quite a end flecks offerer completed. As it stirs, the

flecks are getting smaller a the solution. is lighter bro Color.

Added Nailnoy. Solution the red dark brown again. Where flecks not seen anymore. Solution is miknchaciate braw

Weight of flock 2175.19 (u/ rubier stages)

Began 4 hr heat at 8:33

Sampled intro from the $50 \mathrm{ml}$ pulled before any chemical addict.

$$
\begin{aligned}
& \text { MRR-OI 42.9240 g Initial LAt }=16.8154 \mathrm{~g} \\
& \text { MRrok } \quad I_{\text {ital }} C_{\text {N }}=16.8161 \mathrm{~g}
\end{aligned}
$$

Project No

Date of Work

Entered

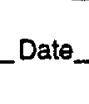

$10 / 2.7 / 99$

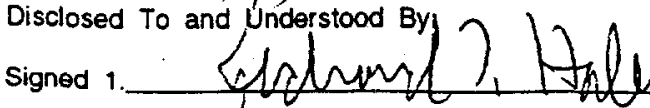

$-12 / 14 / a n$

Date 
12:33 Time for hr digestion finished.

12.4 Temp ranged from $47,5-53.4 \mathrm{C}$ over 4 hrs. Finished with 4 hr e digestion.

Camera recording.

lion $46.4 \mathrm{C}=$ Twist

$1: 26 T=44,1$

$2: 00 T=40.4$

$2 ! 36 T=37.3$

$2: 51: T=36,3$

$3 ; 22 T=34,5$

$4: 061=32.7$

4,18 in 32.3

4i30 Filtering - The solution is filtering very well Their is already $700+$ me of filtrate 11 the collection bottle. Susiliz to add last 1/2 to the * Stir bar slid into the filter. will retene later.

sion Filtucle is mid like.

$\therefore$ 6:05pm Mostly completed filtration of treated archive AN-107

Iojagipg Filled $250 \mathrm{~mL}$ container wy treated, filtered archive fir Mieasilred density of treated, filtered archive AN -jo? Filled MR -03 43.93649 - vial w lid

Weighed receiver bottle of filter unit. AO

Weight of big flask + stopper $=869.3 \mathrm{~g}$

Original tare wo stopper $=736 \mathrm{~g}$

Stopper $=85.29$

Date of Work

Project No

Disclosed To and Ghderstood By /l 1. Dato $10 / 28 / 99$

- $12 / 14 / 99$

2.

Date 


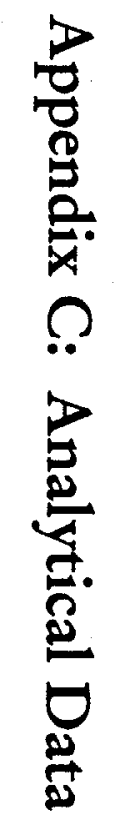




\section{Battelle PNNL/325 B/dg/RPG/Inorganic Analysis ...}

ICPAES Data Report

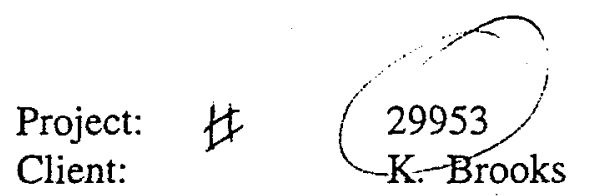
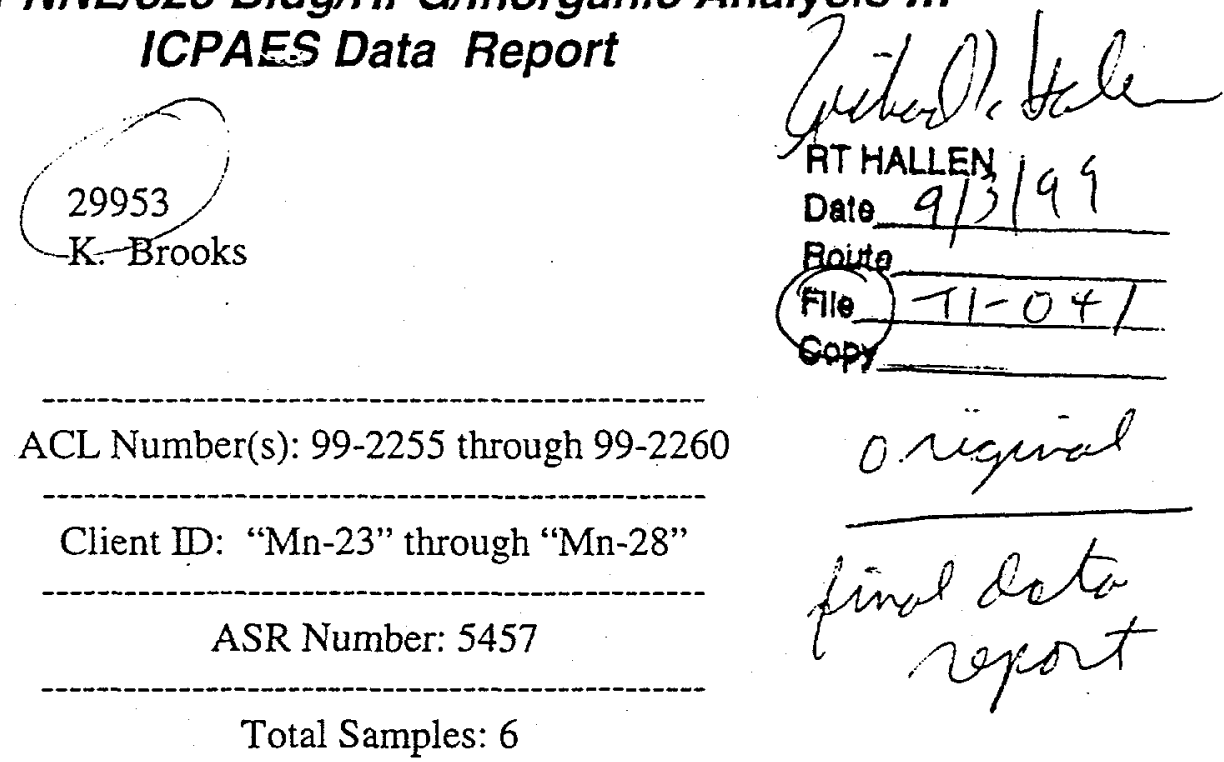

Procedure: PNL-ALO-211, "Determination of Elements by Inductively Coupled Argon Plasma Atomic Emission Spectrometry" (ICP-AES).

Analyst: DR Sanders

Analysis Date (Filename): 08-04-99 (A0538)

See Chemical Measurement Center 98620: ICP-325-405-1 File for Calibration and Maintenance Records.

M\&TE Number:

ICPAES instrument -- WB73520

Mettler AT400 Balance -- Ser.No. 360-06-01-029
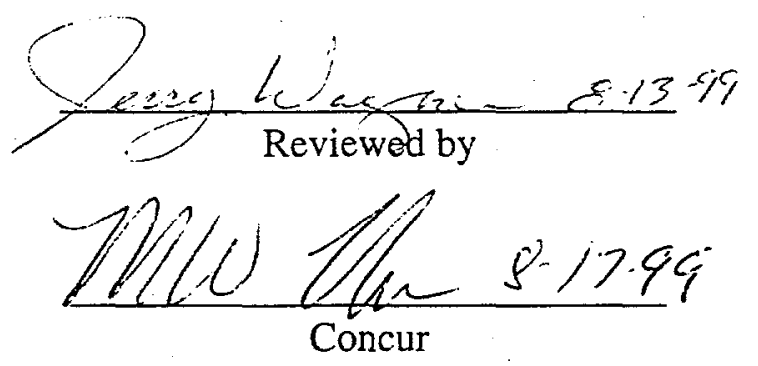

$8 / 13 / 99$ 


\section{Battelle PNNL/325 Bldg/RPG/Inorganic Analysis ... ICPAES DataReport}

Six radioactive aqueous samples, Mn-23 through Mn-28 (ACL\# 99-2255 through 99-2260), were analyzed by ICPAES after preparation by the Sample Receiving and Preparation Laboratory (SRPL). Samples were prepared by SRPL using PNL-ALO-128 acid digestion procedure. All samples were prepared using plastic labware. Approximately $5 \mathrm{ml}$ aliquots of sample solution were weighed, processed and diluted to a final volume of $20 \mathrm{ml}$. All liquid samples were caustic, salt solutions prior to processing. Sample Mn-28 (ACL\# 99-2260) was filtered after being diluted to $20 \mathrm{ml}$ using 0.45 um membrane filter.

All results reported are in $\mu \mathrm{g} / \mathrm{g}$ including liquid samples as requested by client. All results have been corrected for preparation and analytical dilution. Volumes and weights are recorded on bench sheets (included with raw data, etc.). Analytes of interest include $\mathrm{Al}, \mathrm{Ba}, \mathrm{Ca}, \mathrm{Cd}, \mathrm{Co}, \mathrm{Cr}$, $\mathrm{Cu}, \mathrm{Fe}, \mathrm{K}, \mathrm{La}, \mathrm{Mg}, \mathrm{Mn}, \mathrm{Mo}, \mathrm{Na}, \mathrm{Ni}, \mathrm{Pb}, \mathrm{Si}$, Ti, U, and $\mathrm{Zn}$. No changes have been made relative to the preliminary report provided earlier to the client.

All quality control checks met tolerance requirements for analytes of interest except as noted below. Following is a list of quality control check measurement results relative to ICPAES analysis tolerance requirements under MCS-033.

Five fold serial dilution:

(Aqueous samples) All results were within tolerance limit of $\leq 10 \%$ after correcting for dilution.

Duplicate RPD (Relative Percent Difference):

(Aqueous samples) All analytes of interest were recovered within tolerance limit of $\leq 20 \%$ relative percent difference (RPD).

Post-Spiked Samples (Group A):

(Aqueous samples) All analytes of interest were recovered within tolerance of $75 \%$ to $125 \%$.

Post-Spiked Samples (Group B):

(Aqueous samples)

All analytes of interest were recovered within tolerance of $75 \%$ to $125 \%$.

Blank Spike:

(Aqueous samples)

All analytes of interest in the blank spike were recovered within tolerance limit of $80 \%$ to $120 \%$.

$\underline{8 / 13 / 99}$ 


\section{Battelle PNNL/325 BIdg/RPG/Inorganic Analysis ... ICPAES Data Report}

Matrix Spiked Sample:

(Aqueous samples) All analytes of interest in the matrix-spike were recovered within tolerance limit of $75 \%$ to $125 \%$ except for $\mathrm{Ba}$ and $\mathrm{Pb}$. Matrix-spike recovery for barium in sample Mn-22 (ACL\# 99-2259) was only about $5 \%$. Lead recovery in the same sample was about $41 \%$. Low recovery for the two analytes may be caused by moderate to high concentration of sulfate in the sample. Post-spike and blank-spike recovery for all analytes of interest was recovered within tolerance limit of $75 \%$ to $125 \%$.

Quality Control Check Standards:

Concentration of all analytes of interest was within tolerance limit of $\pm 10 \%$ accuracy in the standards: QC_MCVA and QC_MCVB.

Calibration Blank (ICP98.0) concentration was less than two times IDL.

High Calibration Standard Check:

Verification of the high-end calibration accuracy for all analytes of interest except lanthanum and uranium was within $\pm 5 \%$ tolerance. The high-end calibration accuracy for lanthanum was somewhat low, about $-6.9 \%$ and uranium was also low by about $-5.7 \%$. This will cause results for lanthanum and uranium concentration to appear lower than what is actually present in the samples. Lanthanum and uranium concentration measurements were all below EQL (and below MRQ).

Process Blank:

(Aqueous samples) All analytes of interest were within tolerance limit of $\leq \mathrm{EQL}$ or $<5 \%$ of sample concentration.

$\underline{\text { Laboratory Control Standard (LCS): }}$

(Aqueous samples) No LCS was prepared for PNL-ALO-128 acid digested samples.

Analytes other than those requested by the client are for information only. Please note bracketed values listed in the data report are within ten times instrument detection limit and have a potential uncertainty much greater than $15 \%$. See attached ICPAES data results.

$\underline{8 / 13 / 99}$ 


\section{Battelle PNNL/325 BIdg/RPG/Inorganic Analysis ... $\checkmark \quad$ ICPAES Data Report}

Comments:

1) "Final Results" have been corrected for all laboratory dilution performed on the sample during processing and analysis unless specifically noted.

2) Detection limits (DL) shown are for acidified water. Detection limits for other matrices may be determined if requested.

3) Routine precision and bias is typically $\pm 15 \%$ or better for samples in dilute, acidified water (e.g. $2 \% \mathrm{v} / \mathrm{v} \mathrm{HNO}_{3}$ or less) at analyte concentrations greater than ten times detection limit up to the upper calibration level. This also presumes that the total dissolved solids concentration in the sample is less than $5000 \mu \mathrm{g} / \mathrm{mL}(0.5$ per cent by weight).

4) Absolute precision, bias and detection limits may be determined on each sample if required by the client.

5) The maximum number of significant figures for all ICP measurements is 2 . 
Battelle PNNL/RPG/Inorganic Analysis ... ICPAES Data Report Page 1 of 2

\begin{tabular}{|c|c|c|c|c|c|c|}
\hline $\begin{array}{c}\text { Det. Limit } \\
(\mathrm{jg} / \mathrm{mL})\end{array}$ & $\begin{array}{c}\text { Multiplier= } \\
\text { ALOH= } \\
\text { Client ID }= \\
\text { Run Date= } \\
\text { (Analyte) }\end{array}$ & \begin{tabular}{|c|}
3.2 \\
99-2255-PB 1 \\
Process Blank \\
$\begin{array}{c}8 / 4 / 99 \\
u g / 9\end{array}$ \\
\end{tabular} & 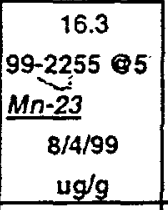 & \begin{tabular}{|c|}
16.4 \\
$99-2256$ Q5 \\
$M n-31$ \\
$8 / 4 / 99$ \\
$u g / g$ \\
\end{tabular} & \begin{tabular}{|c|}
16.3 \\
$99-2257 @ 5$ \\
$M n-32$ \\
$8 / 4 / 99$ \\
$u g / g$ \\
\end{tabular} & $\begin{array}{c}15.9 \\
99-2258 @ 5 \\
M n-21 \\
8 / 4 / 99 \\
u g / g \\
\end{array}$ \\
\hline \multirow{3}{*}{$\begin{array}{l}0.015 \\
0.060 \\
0.080\end{array}$} & \multirow{3}{*}{$\begin{array}{l}\text { Ag } \\
\text { Al } \\
\text { As }\end{array}$} & $=$ & - & - & - & - \\
\hline & & - & 119 & 105 & 106 & 133 \\
\hline & & - & - & - & $=$ & - \\
\hline 0.050 & B & - & 13.8 & 16.4 & 13.8 & 18.5 \\
\hline 0.010 & $\mathrm{Ba}$ & - & [0.33] & - & $=$ & {$[1.3]$} \\
\hline 0.010 & $\mathrm{Be}$ & $=$ & $=$ & - & - & = \\
\hline 0.100 & $\mathrm{Bi}$ & - & - & - & $=$ & - \\
\hline 0.100 & $\mathrm{Ca}$ & - & 130 & 129 & 129 & 227 \\
\hline 0.015 & $\mathrm{~cd}$ & - & 23.2 & 22.6 & 22.5 & 27.0 \\
\hline 0.100 & $\mathrm{Ce}$ & - & - & - & - & {$[9.7]$} \\
\hline 0,025 & Co & - & [1.8] & {$[1.8]$} & [1.8] & [2.0] \\
\hline 0.020 & Cr & - & 35.7 & 36.9 & 36.1 & 58.6 \\
\hline 0.015 & $\mathrm{Cu}$ & {$[0.13]$} & 11.5 & 14.1 & 12.7 & 12.8 \\
\hline 0.050 & Dy & - & - & - & - & - \\
\hline 0.100 & Eu & - & - & $=$ & $=$ & - \\
\hline 0.025 & $\mathrm{Fe}$ & {$[0.13]$} & 8.00 & 7.56 & 5.82 & 445 \\
\hline 2.000 & K & $=$ & 604 & 584 & 592 & 665 \\
\hline 0.025 & $\mathrm{La}$ & - & {$[0.77]$} & {$[0.71]$} & {$[0.74]$} & 9.46 \\
\hline 0.005 & Li & - & {$[0.34]$} & {$[0.26]$} & {$[0.25]$} & {$[0.25]$} \\
\hline 0.100 & $\mathrm{Mg}$ & - & - & - & - & - \\
\hline 0.005 & $\mathrm{Mn}$ & - & 1.13 & {$[0.48]$} & {$[0.50]$} & 44.1 \\
\hline 0.030 & Mo & - & 13.2 & 12.9 & 12.9 & 15.0 \\
\hline 0.100 & $\mathrm{Na}$ & {$[0.75]$} & 84,600 & 84,200 & 86,200 & 104,000 \\
\hline 0.100 & Nd & $=$ & [2.6] & {$[2.9]$} & [2.9] & 29.0 \\
\hline 0.030 & $\mathrm{Ni}$ & - & 189 & 184 & 185 & 217 \\
\hline 0.100 & $P$ & - & 166 & 162 & 163 & 184 \\
\hline 0.060 & $\mathrm{~Pb}$ & - & 69.5 & 66.9 & 67.4 & 134 \\
\hline 0.300 & $\mathrm{Pd}$ & - & - & - & {$[4.9]$} & {$[16]$} \\
\hline 0.300 & Rh. & - & - & - & - & {$[4.8]$} \\
\hline 0.075 & Ru & - & 13.0 & 12.5 & 12.7 & 14.8 \\
\hline 0.050 & Sb & - & $=$ & - & $=$ & $=$ \\
\hline 0.050 & Se & - & {$[1.0]$} & {$[0.94]$} & {$[1.0]$} & {$[1.00]$} \\
\hline 0.100 & $\mathrm{Si}$ & - & 38.2 & 43.8 & 34.4 & 41.9 \\
\hline 1.000 & Sn & - & - & - & $=$ & - \\
\hline 0.005 & Sr & - & 115 & 171 & 159 & 1.14 \\
\hline 0.500 & $\mathrm{Te}$ & - & $=$ & - & $=$ & - \\
\hline 0.800 & Th & $=$ & - & $=$ & - & - \\
\hline 0.005 & $\mathrm{Ti}$ & - & - & - & $=$ & 0.943 \\
\hline 0.250 & $\mathrm{TI}$ & - & - & - & - & - \\
\hline 2.000 & u & - & [40] & [38] & [41] & [48] \\
\hline 0.015 & $\underline{v}$ & - & - & - & - & $=$ \\
\hline 0.500 & $w$ & - & {$[60]$} & [59] & [59] & [70] \\
\hline 0.010 & $Y$ & - & [0.44] & {$[0.59]$} & {$[0.56]$} & 2.81 \\
\hline 0.020 & $\mathrm{Zn}$ & {$[0.18]$} & 5.19 & 5.48 & 5.39 & 9.36 \\
\hline 0.025 & $\mathbf{Z}_{r}$ & - & {$[1.1]$} & {$[1.2]$} & {$[0.94]$} & 14.3 \\
\hline & & Note: 1) Overa & than 10-tin & it is estimat & $-15 \%$ & \\
\hline & & 2) Values in bra & ithin 10-time & it with errors & $15 \%$ & \\
\hline & & 3) "-.." indicate $m$ & is below det & e detection lim & dby & \\
\hline & & multiolving "det & column) by & o of each colun & & \\
\hline
\end{tabular}


Battelle PNNL/RPG/Inorganic Analysis ... ICPAES Data Report Page 2 of 2

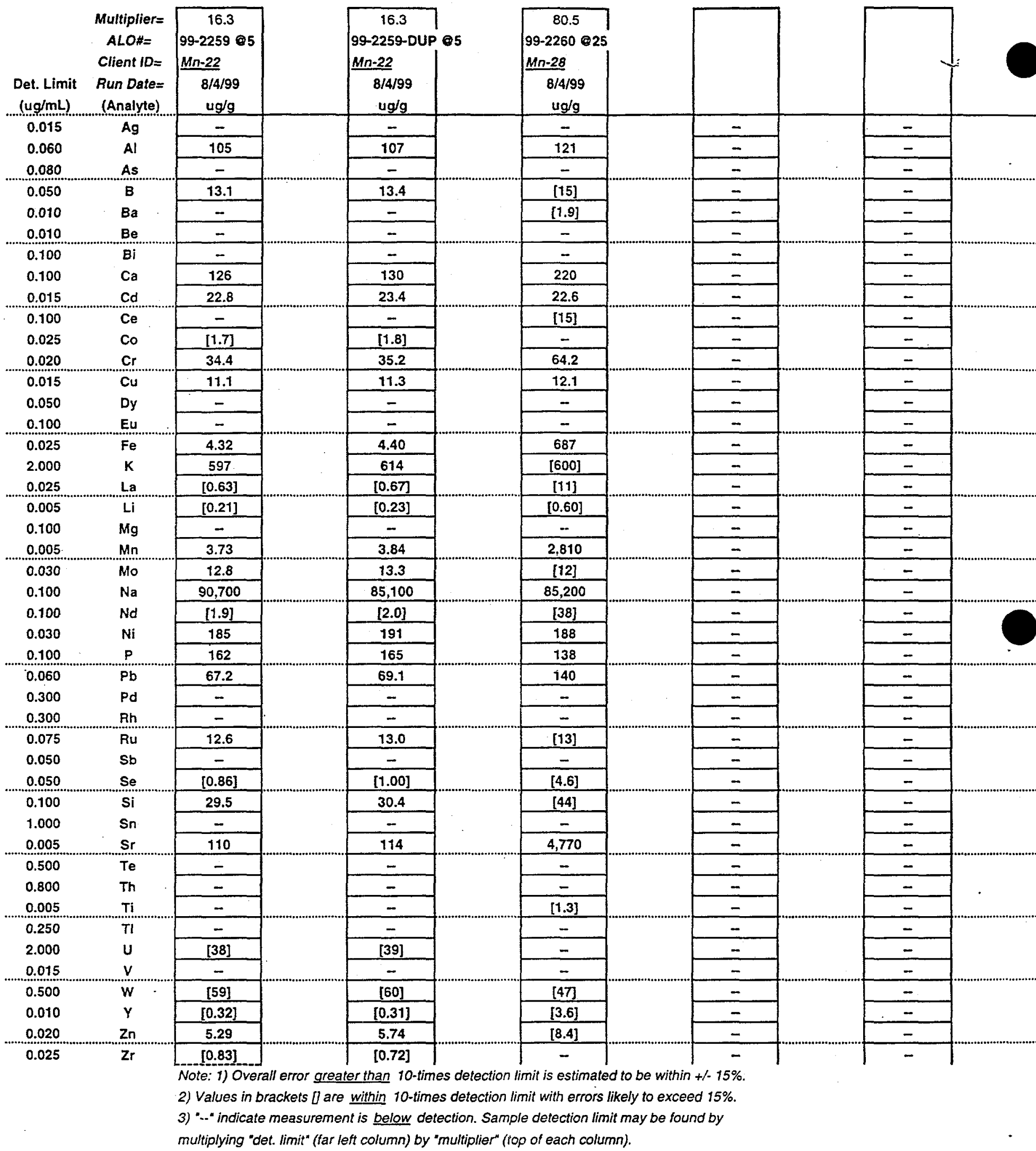


Battelle Pacific Northwest Laboratory

Radiochemical Processing Group-325 Building

Radioanalytical Applications Team
ASR \#

5457

WP\#

\section{W51304}

File: L:Iradchem $h y$ droxidelasr 5457

Analysis Date: 13 Print Date: $8 / 4 / 99$

Hydroxide and Alkalinity Determination

Governing Procedures: PNL-ALO-228: Determination of Hydroxyl (OH-) and

Alkalinity of Aqueous Solutions, Leachates and Supernates and Operation of Brinkman 636 Auto-Titrator

Equip \# WB76843

Lab Loc. $\quad 525$

\begin{tabular}{|c|c|}
\hline Titrant & Molarity \\
\hline $\mathrm{HCl}$ & $\mathbf{0 . 2 0 3 4}$ \\
\hline
\end{tabular}

\begin{tabular}{|c|c|}
\hline Std. \& Spike & Molarity \\
\hline $\mathrm{NaOH}$ & $\mathbf{0 . 1 0 1 8}$ \\
\hline
\end{tabular}

\begin{tabular}{|c|c|c|c|c|}
\hline RPG \# & Sample ID & & $\begin{array}{r}\text { Sample } \\
\text { Vol. (mL) }\end{array}$ & $\begin{array}{l}\text { Sample } \\
\text { Wt. (g) }\end{array}$ \\
\hline $99-2258$ & $\mathrm{Mn}-21$ & & 0.100 & 0.1271 \\
\hline $99-2258$ & $\mathrm{Mn}-21$ & Replicate & 0.200 & 0.2547 \\
\hline $99-2259$ & $M n-22$ & & 0.200 & 0.2485 \\
\hline $99-2259$ & $M n-22$ & Replicate & 0.200 & 0.2494 \\
\hline QC Data: & & & & \\
\hline Reag. Blk. & & & 5.00 & \\
\hline Standard 1 & $0.1018 \mathrm{~N} \mathrm{NaOH}$ & & 5.000 & 5.0036 \\
\hline Standard 2 & $0.1018 \mathrm{~N} \mathrm{NaOH}$ & & 5.000 & 5.0196 \\
\hline 99-2258MS & \multicolumn{2}{|c|}{$\mathrm{Mn}-21+2 \mathrm{~mL} 0.1 \mathrm{~N} \mathrm{NaOH}$} & 0.100 & 0.1256 \\
\hline 99-2259MS & \multicolumn{2}{|c|}{$\mathrm{Mn}-22+2 \mathrm{~mL} \mathrm{0.1N} \mathrm{NaOH}$} & 0.100 & 0.1229 \\
\hline \multicolumn{5}{|c|}{2} \\
\hline Buffer & \multicolumn{2}{|c|}{ VWR Lot \# } & CMS\# & Expire Date \\
\hline 10 & \multicolumn{2}{|c|}{$981659-24$} & 144109 & Jul-00 \\
\hline 4 & \multicolumn{2}{|c|}{$981583-24$} & 144107 & Jun-00 \\
\hline 7 & \multicolumn{2}{|c|}{$981894-24$} & 144108 & Aug-00 \\
\hline
\end{tabular}

Titrator

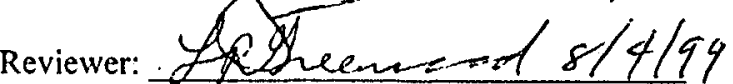

$\mathrm{OH}$

\begin{tabular}{|r|r|r|r|r|r|}
\cline { 2 - 6 } $\begin{array}{c}\text { Initial } \\
\text { pH } \\
\text { reading }\end{array}$ & $\begin{array}{c}\text { 1st Equivalence } \\
\text { Point } \\
\text { Titrant } \\
\text { Vol. }(\mathrm{mL})\end{array}$ & \multicolumn{1}{c|}{$\begin{array}{c}\text { Found } \\
\text { millimoles } \\
\text { base }\end{array}$} & $\begin{array}{c}\text { Molarity } \\
\text { base }\end{array}$ & $\begin{array}{r}\text { millimole } \\
\text { RPD }\end{array}$ \\
\hline 11.558 & 0.423 & 10.624 & 0.086 & 0.86 & \\
\hline 11.759 & 0.855 & 10.750 & 0.174 & 0.87 & $1.06 \%$ \\
\hline 11.702 & 0.723 & 10.67 & 0.147 & 0.74 & \\
\hline 11.707 & 0.724 & 10.699 & 0.147 & 0.74 & $0.14 \%$ \\
\hline 6.143 & & & & & \\
\hline 12.026 & 2.492 & 7.918 & 0.5069 & $99.6 \%$ & Std 1 \\
\hline 11.89 & 2.486 & 7.578 & 0.5057 & $99.3 \%$ & Std 2 \\
\hline 11.846 & 1.338 & 10.611 & 0.272 & $91.2 \%$ & MS \\
\hline 11.702 & 1.292 & 10.640 & 0.263 & $92.9 \%$ & MS \\
\hline
\end{tabular}

Performance checks

Balance \# 360--01-06-037

\begin{tabular}{|c|c|c|c|}
\hline 360--01-06-037 & Vol. & Wt. \\
\hline Pipet \# & H30762 & 5.00 & 4.944 \\
\hline Pipet \# & 2734494 & 0.500 & 0.496 \\
\hline Pipet \# & 120737 & 0.100 & 0.1013 \\
\hline Pipet \# & 120737 & 0.200 & 0.1997 \\
\hline
\end{tabular}

Boute

Fir T1-0屯

copy origihal

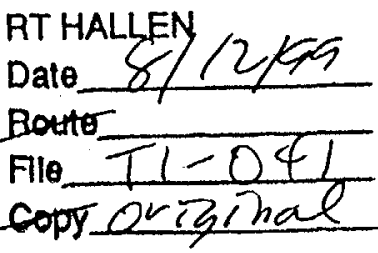


Battelle Pacific Northwest Laboratory

Radiochemical Processing Group-325 Building

Radioanalytical Applications Team

Hydroxide and Alkalinity Determination

Governing Procedures: PNL-ALO-228: Determination of Hydroxyl (OH-) and

Alkalinity of Aqueous Solutions, Leachates and Supernates

and

Operation of Brinkman 636 Auto-Titrator

Equip \# WB76843

Lab Loc. $\quad 525$

\begin{tabular}{|lr|}
\hline Titrant & Molarity \\
\hline $\mathrm{HCl}$ & $\mathbf{0 . 2 0 3 4}$ \\
\hline
\end{tabular}

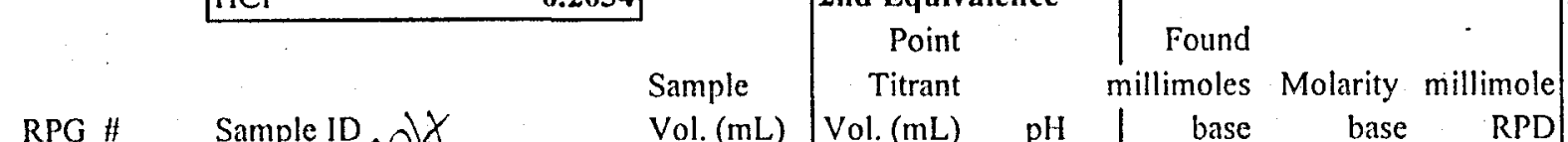

$\mathrm{CO3}$

\begin{tabular}{|c|c|c|c|c|c|c|c|c|c|c|c|}
\hline RPG \# & Sample ID & & \multirow{2}{*}{$\begin{array}{r}\text { Vol. (mL) } \\
0.100\end{array}$} & \multirow{2}{*}{\begin{tabular}{|r|} 
Vol. $(\mathrm{mL})$ \\
0.859 \\
\end{tabular}} & \multirow{2}{*}{$\frac{\mathrm{pH}}{7.658}$} & base & base & \multicolumn{2}{|c|}{ RPD Vol. (mL) } & $\mathrm{pH}$ & \\
\hline $99-2258$ & \multirow{3}{*}{$\begin{array}{l}\mathrm{Mn}-21 \\
\mathrm{Mn}(-22) 2 \\
\mathrm{Mn}-22\end{array}$} & \multirow{2}{*}{0} & & & & 0.089 & 0.887 & & 1.314 & 4.427 & 0. \\
\hline $99-2258$ & & & 0.200 & 1.720 & 7.793 & 0.176 & 0.880 & $0.81 \%$ & 2.617 & 4.526 & 0 . \\
\hline $99-2259$ & & 0 & 0.200 & 1.460 & 7.670 & 0.150 & 0.750 & & 2.210 & 4.573 & 0. \\
\hline $99-2259$ & $\mathrm{Mn}-22$ & Replicate & 0.200 & 1.454 & 7.808 & 0.148 & 0.742 & $0.95 \%$ & 2.211 & 4.581 & 0. \\
\hline & & & & & & & & & & & \\
\hline racy & & & & & & & \multicolumn{2}{|c|}{ CO3 \% Recovered } & & & \\
\hline Standard 1 & $0.1018 \mathrm{~N} \mathrm{NaOH}$ & & 5.000 & 2.559 & 4.054 & 0.01363 & 0.003 & sample & & \multirow{2}{*}{\multicolumn{2}{|c|}{$\mathrm{HCO} 3$}} \\
\hline Standard 2 & $0.1018 \mathrm{~N} \mathrm{NaOH}$ & & 5.000 & 2.566 & 3.879 & 0.01627 & 0.003 & sample & & & \\
\hline 99-2258MS & \multicolumn{2}{|c|}{$\mathrm{Mn}-21+2 \mathrm{~mL} 0.1 \mathrm{~N} \mathrm{NaOH}$} & 0.100 & 1.825 & 7.723 & 0.09906 & $112.1 \%$ & sample & 2.324 & 4.573 & 0. \\
\hline 99-2259MS & \multicolumn{2}{|c|}{$\mathrm{Mn}-22+2 \mathrm{~mL} 0.1 \mathrm{~N} \mathrm{NaOH}$} & 0.100 & 1.715 & 7.7 & 0.08604 & $115.3 \%$ & sample & 2.146 & 4.495 & 0. \\
\hline
\end{tabular}

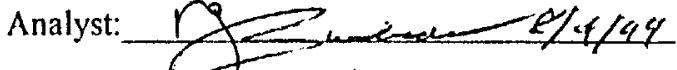

Reviewer:

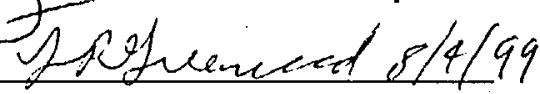

$\mathrm{HCO} 3$

3rd Equivalence

Point

Found

millimoles Molarity millimole

Prep record on $0.2034 \mathrm{M} \mathrm{HCl}$ is on following page. 


\section{Chem Rec 51a}

Prep date: 4/18/99

Preparation of Standardized $0.2 \mathrm{M} \mathrm{HCl}$

WP\# $\mathrm{K} 51300$

Standardized $0.1021 \mathrm{M} \mathrm{NaOH}$ will be re-checked and then used to standardized the $\sim 0.1 \mathrm{M} \mathrm{HCl}$ solution. The 0.1021 M NaOH was prepared in Chem Rec_37 ( see Chem Rec_37 --prep.date 2-25-98 for original data) and re-verified against NIST SRM84j Potassium Acid Phthalate KHC8H404 (KAP) $=204.23 \mathrm{~g} /$ mole -- Barcode \# 52232 --- (see below verification check).

The re-standardized value of $0.1018 \mathrm{M} \mathrm{NaOH}$ was reassigned to this $\mathrm{NaOH}$ solution with a revised Expiration Date of Feb. 2000.

Prepared 1- liters of $-0.2 \mathrm{M} \mathrm{HCl}$ by diluting $100 \mathrm{~mL}$ of $1.029 \mathrm{M} \mathrm{HCl}$ (Chemrec_10) to $0.5 \mathrm{~L}$ with Dl. $\mathrm{H} 2 \mathrm{O}$.

$20 \mathrm{~mL}$ aliquots of $0.2 \mathrm{M} \mathrm{HCl}$ were were neutralized to the phenopthalien endpoint using the re-standardized $0.1018 \mathrm{M}$ $\mathrm{NaOH}$. The volume of $\mathrm{NaOH}$ is accurate to $+1-0.02 \mathrm{~mL}$ and the pipitting error is estimated to be $<1 \%$ @ $1 \mathrm{~s}$. Thus total error is $<3 \%$ for the measurements

$\mathrm{NaOH}$ Molarity veification

\begin{tabular}{|c|c|c|c|c|}
\hline Verification Test \# & Wt. of KAP & $\begin{array}{c}\text { Vol. of } 0.102 \mathrm{TMNaOH} \\
\text { to neutralize }\end{array}$ & $\begin{array}{l}\text { NaOH Molarity }=a^{*} \\
1000 / b * 204.23\end{array}$ & $\begin{array}{l}\text { Molarity Error } \\
+1 \text { - @ } 1 \mathrm{~s}\end{array}$ \\
\hline$T$ & 0.80894 & 38.95 & 0.1017 & \\
\hline 2 & 0.80582 & 38.84 & 0.1016 & \\
\hline 3 & 0.96233 & 46.12 & 0.1022 & \\
\hline \multicolumn{3}{|r|}{ Ave $=$} & $\frac{0.1018}{\text { re-certified value }}$ & 0.0003 \\
\hline
\end{tabular}

\begin{tabular}{|c|c|c|c|c|}
\hline Titration Id. & $\begin{array}{l}\text { aliquot of } \\
\text { sample }\end{array}$ & $\begin{array}{c}\text { Vo. of } 0.1078 \mathrm{M} \text { NaOH } \\
\text { to neutralize }\end{array}$ & $\begin{array}{l}\text { Molarity of Acidin } \\
\text { Sample }\end{array}$ & $\begin{array}{l}\text { Molarity Error } \\
+1-@ 1 \mathrm{~s}\end{array}$ \\
\hline 1 & 20.00 & 39.88 & 0.2030 & \\
\hline 2 & 20.00 & 39.92 & 0.2032 & \\
\hline 3 & 20.00 & 40.04 & 0.2038 & \\
\hline & & Ave Molarity $\mathrm{HCl}=$ & 0.2034 & 0.00042 \\
\hline
\end{tabular}

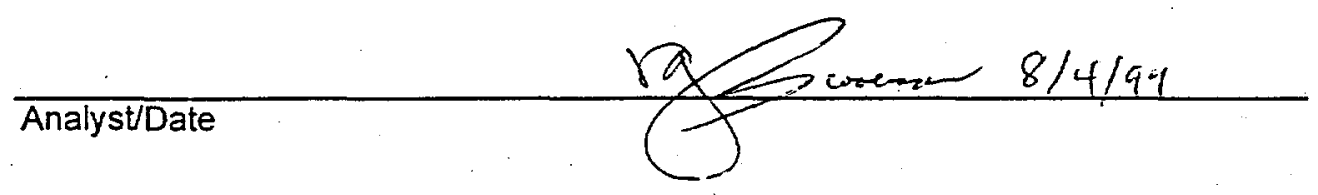


Battelle Pacific Northwest Laboratory

Radiochemical Processing Group-325 Building

$99-2255$

Radioanalytical Applications Team

$8 / 6 / 99$

Client: Brooks

Cognizant Scientist:

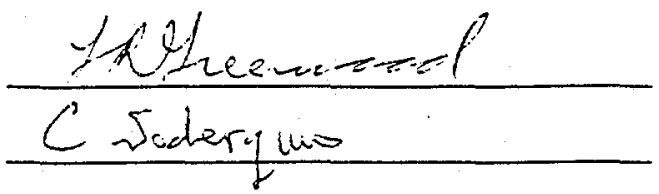

Date: $8-6-99$

Concur :

Date: $8-6.99$

Sr-90 (PNL-ALO-476, 431)

Gamma (PNL-ALO-450)

Measured Activities (uCi/m)

\begin{tabular}{|c|c|c|c|c|c|c|c|c|}
\hline $\begin{array}{l}\text { ALO ID } \\
\text { Client ID }\end{array}$ & $\begin{array}{l}\text { Co-60 } \\
\text { Error \% } \\
\end{array}$ & $\begin{array}{l}\text { Eu- } 152 \\
\text { Error \% }\end{array}$ & $\begin{array}{l}\text { Cs-137 } \\
\text { Error \% } \\
\end{array}$ & $\begin{array}{l}\text { Eu- } 154 \\
\text { Error \% }\end{array}$ & $\begin{array}{l}\text { Sb- } 125 \\
\text { Error \% } \\
\end{array}$ & $\begin{array}{c}\text { SnSb- } 126 \\
\text { Error \% } \\
\end{array}$ & $\begin{array}{l}\text { Eu. } 155 \\
\text { Error \% }\end{array}$ & $\begin{array}{l}\text { Am-241 } \\
\text { Error \% }\end{array}$ \\
\hline $99-2255 P B$ & $<2 . E-5$ & $<4 . E-5$ & $<2 . E-5$ & $<4 . E-5$ & $<3 . E-5$ & $<1 . E-5$ & $<5$. E. 5 & $<9 . E-5$ \\
\hline \multicolumn{9}{|l|}{ Process Blank } \\
\hline 99.2255 & $6.21 E-2$ & $<2 . E-3$ & $6.52 E-2$ & $2.20 E-2$ & $<9 . \mathrm{E}-4$ & $4.31 E-4$ & $1.65 \mathrm{E}-2$ & $9.48 E-3$ \\
\hline $\mathrm{Mn}-23$ & $2 \%$ & & $2 \%$ & $2 \%$ & & $22 \%$ & $3 \%$ & $8 \%$ \\
\hline $99-2256$ & $6.02 \mathrm{E}-2$ & $<2 . E-3$ & $4.03 E \cdot 2$ & $2.95 E-2$ & $1.12 \mathrm{E}-3$ & $3.89 E-4$ & $2.15 \mathrm{E}-2$ & $9.77 E-3$ \\
\hline $\mathrm{Mn}-31$ & $2 \%$ & & $2 \%$ & $2 \%$ & $25 \%$ & $16 \%$ & $3 \%$ & $8 \%$ \\
\hline 99.2257 & $6.22 E-2$ & $<2 . \mathrm{E}-3$ & $4.45 E-2$ & $2.86 E-2$ & $<9 . E \cdot 4$ & $2.69 E-4$ & $2.17 \mathrm{E}-2$ & $1.09 E-2$ \\
\hline $\mathrm{Mn} \cdot 32$ & $2 \%$ & & $2 \%$ & $2 \%$ & & $17 \%$ & $3 \%$ & $7 \%$ \\
\hline $99-2258$ & $7.74 E-2$ & $5.02 \mathrm{E}-3$ & $2.83 E-2$ & $2.91 E-1$ & $<2 . E \cdot 3$ & $<6 . E-4$ & $2.08 E-1$ & $2.19 E-1$ \\
\hline$M n-21$ & $2 \%$ & $8 \%$ & $2 \%$ & $2 \%$ & & & $3 \%$ & $5 \%$ \\
\hline $\begin{array}{l}99-2259 \\
\mathrm{Mn}-22\end{array}$ & $\begin{array}{c}6.68 E-2 \\
2 \%\end{array}$ & $<2 . E \cdot 3$ & $\begin{array}{c}2.31 E-2 \\
2 \%\end{array}$ & $\begin{array}{c}1.65 \mathrm{E}-2 \\
2 \%\end{array}$ & $<8 . E \cdot 4$ & $\begin{array}{c}3.89 E-4 \\
16 \%\end{array}$ & $\begin{array}{c}1.19 E-2 \\
4 \%\end{array}$ & $\begin{array}{c}5.56 E-3 \\
15 \%\end{array}$ \\
\hline 99-2259 Dup 1 & $6.68 \mathrm{E}-2$ & $<2 . E \cdot 3$ & $2.34 E-2$ & $1.73 E-2$ & $<8 . E-4$ & $3.86 \mathrm{E}-4$ & $1.19 \mathrm{E}-2$ & $7.27 E-3$ \\
\hline$M n-22$ & $2 \%$ & & $2 \%$ & $2 \%$ & & $18 \%$ & $4 \%$ & $15 \%$ \\
\hline RPD & $0 \%$ & & $1 \%$ & $5 \%$ & & $1 \%$ & $0 \%$ & $27 \%$ \\
\hline 99-2259 Dup 2 & $6.55 E-2$ & $<2 . E-3$ & $2.20 E-2$ & $1.64 \mathrm{E}-2$ & $<8 . E-4$ & $2.87 E-4$ & $1.21 E-2$ & $5.04 E-3$ \\
\hline $\mathrm{Mn}-22$ & $2 \%$ & & $2 \%$ & $2 \%$ & & $21 \%$ & $5 \%$ & $17 \%$ \\
\hline $99-2260$ & $6.38 E-2$ & $6.14 E-3$ & $3.05 E-2$ & $3.59 E-1$ & $<2 . E-3$ & $<6 . E-4$ & $2.59 E-1$ & $2.63 \mathrm{E}-1$ \\
\hline$M n-28$ & $2 \%$ & $9 \%$ & $3 \%$ & $1 \%$ & & & $3 \%$ & $11 \%$ \\
\hline
\end{tabular}

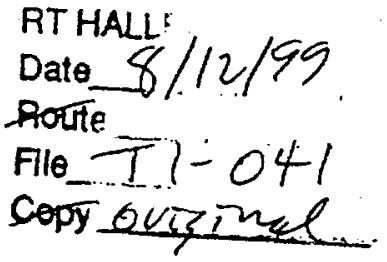


Battelle Pacific Northwest Laboratory

Radiochemical Processing Group-325 Building

99-2255

Radioanalytical Applications Team

$8 / 6 / 99$

Client: Brooks '

Cagnizant Scientist:

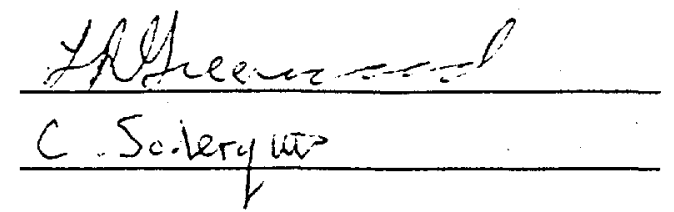

Date: $8-6-79$

Concur :

Date :

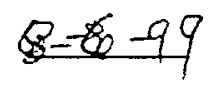

Sr-90 (PNL-ALO-476, 431)

Gamma (PNL-ALO-450)

Measured Activities (uCi/g)

\begin{tabular}{|c|c|c|c|c|c|c|c|c|}
\hline $\begin{array}{l}\text { ALO ID } \\
\text { Client ID }\end{array}$ & $\begin{array}{c}\text { Co-60 } \\
\text { Error \% } \\
\end{array}$ & $\begin{array}{l}\text { Eu-152 } \\
\text { Error \% }\end{array}$ & $\begin{array}{l}\text { Cs-137 } \\
\text { Error \% } \\
\end{array}$ & $\begin{array}{l}\text { Eu-154 } \\
\text { Error \% }\end{array}$ & $\begin{array}{l}\text { Sb- } 125 \\
\text { Error \% }\end{array}$ & $\begin{array}{c}\text { SnSb- } 126 \\
\text { Error } \%\end{array}$ & $\begin{array}{l}\text { Eu- } 155 \\
\text { Error \% } \\
\end{array}$ & $\begin{array}{l}\text { Am-241 } \\
\text { Error \% }\end{array}$ \\
\hline $\begin{array}{l}99-2255 P B \\
\text { Pracess Blank }\end{array}$ & $<2 . E-5$ & $<4 . E-5$ & $<2 . E-5$ & $<4 . E-5$ & $<3 . E-5$ & $<1 . E-5$ & $<5 . E-5$ & $<9 . E .5$ \\
\hline $99-2255$ & $5.09 E-2$ & $1.64 E-3$ & $5.34 E-2$ & $1.80 E-2$ & $7.37 E-4$ & $3.53 E-4$ & $1.35 E-2$ & $7.77 E-3$ \\
\hline $\mathrm{Mn}-23$ & $2 \%$ & & $2 \%$ & $2 \%$ & & $22 \%$ & $3 \%$ & $8 \%$ \\
\hline $99-2256$ & $4.94 \mathrm{E}-2$ & $1.64 \mathrm{E}-3$ & $3.30 \mathrm{E}-2$ & $2.42 E-2$ & $9.18 E-4$ & $3.19 \mathrm{E}-4$ & $1.76 E-2$ & $8.01 \mathrm{E}-3$ \\
\hline$M n-31$ & $2 \%$ & & $2 \%$ & $2 \%$ & $25 \%$ & $16 \%$ & $3 \%$ & $8 \%$ \\
\hline $99-2257$ & $5.09 \mathrm{E}-2$ & $1.64 \mathrm{E}-3$ & $3.64 E-2$ & $2.34 E-2$ & $7.37 E-4$ & $2.20 E-4$ & $1.73 E \cdot 2$ & $8.92 E-3$ \\
\hline$M n-32$ & $2 \%$ & & $2 \%$ & $2 \%$ & & $17 \%$ & $3 \%$ & $7 \%$ \\
\hline $99-2258$ & $6.16 \mathrm{E}-2$ & $4.00 E-3$ & $2.25 E-2$ & $2.32 E-1$ & $1.59 E-3$ & $4.78 E-4$ & $1.66 E-1$ & $1.74 E-1$ \\
\hline$M n-21$ & $2 \%$ & $8 \%$ & $2 \%$ & $2 \%$ & & & $3 \%$ & $5 \%$ \\
\hline $\begin{array}{l}99.2259 \\
M n-22\end{array}$ & $\begin{array}{c}5.45 E-2 \\
2 \%\end{array}$ & $1.63 \mathrm{E}-3$ & $\begin{array}{c}1.88 \mathrm{E}-2 \\
2 \%\end{array}$ & $\begin{array}{c}1.35 \mathrm{E}-2 \\
2 \%\end{array}$ & $6.52 E-4$ & $\begin{array}{c}3.17 \mathrm{E}-4 \\
16 \%\end{array}$ & $\begin{array}{c}9.7 O E-3 \\
4 \%\end{array}$ & $\begin{array}{c}4.53 E-3 \\
15 \%\end{array}$ \\
\hline 99.2259 Dup 1 & $5.44 \mathrm{E}-2$ & $1.63 \mathrm{E}-3$ & $1.91 E-2$ & $1.41 \mathrm{E}-2$ & $6.52 \mathrm{E}-4$ & $3.15 E-4$ & $9.70 \mathrm{E}-3$ & $5.92 E-3$ \\
\hline$M n-22$ & $2 \%$ & & $2 \%$ & $2 \%$ & & $18 \%$ & $4 \%$ & $15 \%$ \\
\hline RPD & $0 \%$ & & $1 \%$ & $5 \%$ & & $1 \%$ & $0 \%$ & $27 \%$ \\
\hline 99-2259 Dup 2 & $5.33 E-2$ & $1.63 E-3$ & $1.79 E-2$ & $1.34 \mathrm{E}-2$ & $6.51 \mathrm{E}-4$ & $2.34 E-4$ & $9.85 E-3$ & $4.10 \mathrm{E}-3$ \\
\hline $\mathrm{Mn}-22$ & $2 \%$ & & $2 \%$ & $2 \%$ & & $21 \%$ & $5 \%$ & $17 \%$ \\
\hline 99.2260 & $5.15 \mathrm{E}-2$ & $4.95 E-3$ & $2.46 \mathrm{E}-2$ & $2.90 \mathrm{E}-1$ & $1.61 E-3$ & $4.84 E-4$ & $2.09 \mathrm{E}-1$ & 2. $12 \mathrm{E}-1$ \\
\hline$M n-28$ & $2 \%$ & $9 \%$ & $3 \%$ & $1 \%$ & & & $3 \%$ & $11 \%$ \\
\hline
\end{tabular}


Client : Brooks

Cognizant Scientist:

Concur :

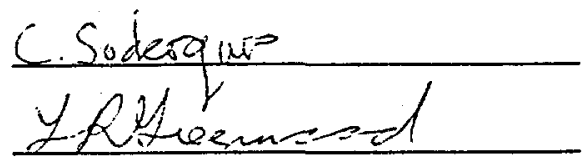

Date: $\quad \frac{8 \cdot 6-99}{\text { Date }: \quad 8-6-99}$

Sr-90 (PNL-ALO-476, 431)

Gamma (PNL-ALO-450)

ALO ID

Client ID

99-2255PB

Process Blank

99-2255

$\mathrm{Mn}-23$

99-2255DUP

$\mathrm{Mn}-23$

RPD

99-2256

Mn-31

99-2257

$\mathrm{Mn}-32$

99-2258

$\mathrm{Mn}-21$

99-2259

$\mathrm{Mn}-22$

99-2260

$\mathrm{Mn}-28$

Matrix Spike

Reagent Spike

Blank

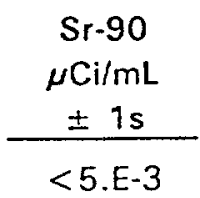

$1.96 \mathrm{E}+0$

$\pm 4 \%$

$2.22 E+0$

$\pm 4 \%$

$12 \%$

$1.99 E+0$

$\pm 4 \%$

1.220

$2.22 E+O$

$\pm 4 \%$

1.221

4. $84 E+1$

$\pm 4 \%$

$1.87 E+0$.

$\pm 3 \%$

1.228

$3.31 E+1$

$\pm 3 \%$

1.240

Sample
Density,
$\mathrm{g}$ per $\mathrm{mL}$

1.221

1.221

1.256

$88 \%$

$102 \%$

$<5$. E-3
$1.63 E+0$

$\pm 4 \%$

$1.82 E+0$

$\pm 4 \%$

$3.85 E+1$

$\pm 4 \%$

$1.52 E+0$

$\pm 3 \%$

2. $67 \mathrm{E}+1$

$\pm 3 \%$ 
Radioanalytical Applications Team

Client : Brooks

Cognizant Scientist:

Concur :

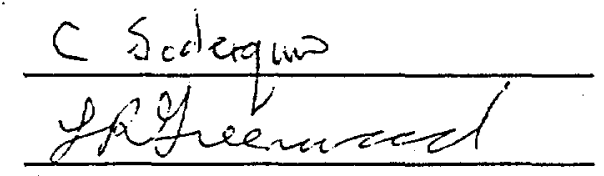

$\begin{array}{ll}\text { Date : } & \frac{8-6-99}{8 / 6 / 49} \\ \text { Date : } & 8 / 6 / 4\end{array}$

Sr-90 (PNL-ALO-476, 431)

Gamma (PNL-ALO-450)

ALO ID

Client ID

99-2255

$\mathrm{Mn}-23$

$99-2256$

$\mathrm{Mn}-31$

99-2257

$\mathrm{Mn}-32$

99-2258

$\mathrm{Mn}-21$

99-2259

$\mathrm{Mn}-22$

99-2259 Dup 1

$\mathrm{Mn}-22$

99-2259 Dup 2

$\mathrm{Mn}-22$

$99-2260$

$\mathrm{Mn}-28$.
Densities of Samples

\begin{tabular}{ccccc} 
Gross & Tare & Net & Volume & Density \\
\hline $14.1799 \mathrm{~g}$ & $8.0603 \mathrm{~g}$ & $6.1196 \mathrm{~g}$ & $5.01 \mathrm{~mL}$ & $1.221 \mathrm{~g} / \mathrm{mL}$
\end{tabular}

$14.3510 \mathrm{~g} 8.2358 \mathrm{~g}$

$6.1152 \mathrm{~g} \quad 5.01 \mathrm{~mL} \quad 1.220 \mathrm{~g} / \mathrm{mL}$

14.1705 g 8.0474

$6.1231 \mathrm{~g} \quad 5.01 \mathrm{~mL} \quad 1.221 \mathrm{~g} / \mathrm{mL}$

$14.4554 \mathrm{~g}$

$8.1599 \mathrm{~g}$

$6.2955 \mathrm{~g}$

$5.01 \mathrm{~mL} \quad 1.256 \mathrm{~g} / \mathrm{mL}$

$14.2015 \mathrm{~g} \quad 8.0536 \mathrm{~g}$

$6.1479 \mathrm{~g}$

$5.01 \mathrm{~mL} \quad 1.226 \mathrm{~g} / \mathrm{mL}$

$14.3323 \mathrm{~g}$

$8.1806 \mathrm{~g}$

$6.1517 \mathrm{~g}$

$5.01 \mathrm{~mL}$

$1.227 \mathrm{~g} / \mathrm{mL}$

$14.2551 \mathrm{~g} \quad 8.0797 \mathrm{~g}$

$6.1754 \mathrm{~g}$

$5.01 \mathrm{~mL}$

$1.232 \mathrm{~g} / \mathrm{mL}$

Average, $\mathrm{n}=3 \quad 1.228 \mathrm{~g} / \mathrm{mL}$ $\pm \quad 0.2 \%$

$\begin{array}{lllll}14.3292 \mathrm{~g} & 8.1147 \mathrm{~g} & 6.2145 \mathrm{~g} \quad 5.01 \mathrm{~mL} \quad 1.240 \mathrm{~g} / \mathrm{mL}\end{array}$

Volume is known to $\pm 0.2 \%, 1 \mathrm{~s}$. 
Analytical Chemistry Laboratory (ACL) Analytical Services Request (ASR) (Cover Page ... information applicable tp all samples in series)

Requested By:

Brouks Mriston

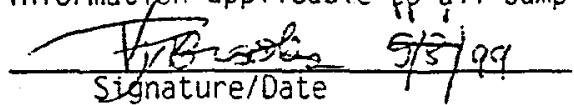

$\frac{6-2233}{\text { Phone }}$

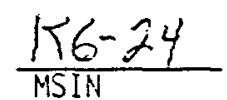

Requester. Please Complete All Fields In This Section. Unless Specified "Optional" or ASR is a Revision

Request ID (optiona1):

PNL Project Number (if known): 2.9953

Work Order/Pkg.: 1453400

Cost Estimate (\$):

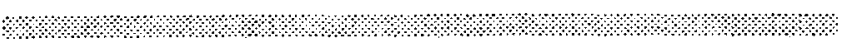
Protocol Requirement: XNone_RCRA_CERCLA.or

Other (specify):

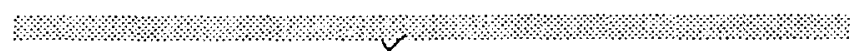
Hold Time Requirement: XNone _RCRA_CERCLA or

Other (specify):

\%ి

TPA Support:

$X^{\text {No. or }}$

Milestone No.:

\%њ

QA Plan:

_MCS-033, or

Other ACL QA Plan (specify): $56 M$

Additional QA Requirements: XNo. or

Reference Doc.:

$\% \cdots \cdots \cdots \cdots \cdots \cdots \cdots \cdots \cdots \cdots$

ACL COC Req'd (PNL-ALO-010): XNo _Yes

ঝ

Sample Storage Requirements: \o _Refrigerate. or

Other (specify):

\%

Date Sampled (optional):

Time Sampled (optional):
Matrix:_Samples vary (specify on Request Page). or

Liquid: XAqueous _organic _Muti-phasic

Solid: _Soil _Sludge _Sediment _Glass

_Filter _Smear Metel _organic _other Solids

Solid/Liquid Mixture: _ Gas: _

Biological: -Tissue Urine _Feces

१ै

Process Knowledge: _Sample Information Check List.

or Reference Doc.:

PCBs Present: Xivo _Yes

१ै।

Sample Disposition ...

Untreated Sample(5): _Return Xoispose _Store. or

Reference Doc.:

Prep'd Sample(s): XDispose _Return _Store. or Reference Doc.:

१७ Additional Instructions: No. or

Reference Doc: :

\%া Date Report Req'd: $\quad \mid z-1-99$

Send Report to:

Rich Hallen

MSIN: $52-12$ Phone: $375-6919$

Fax (optional): $372-4732$

For ACL Use Only ... Do Not Complete This Section

Date Delivered: $11 / 1 / 99$

ACL Numbers:

Time Delivered (optional):

Deliv. By (if known):

Mike MANA

Received by:

Fu Hoopes

Resp. ACl Mgr. :

Signatureloate:

Job Group (optional):

Sample Group (optional):

PNL Impact Level: - 1 - $2-3$

OO Review Req'd: XNo _Yes ACL Waste: XNo _Yes

ASR Number:

Revision: _Yes 
Analytical Chemistry Laboratory (ACL) Analytical Services Request (ASR) (Request Page ... information specific to individual samples)
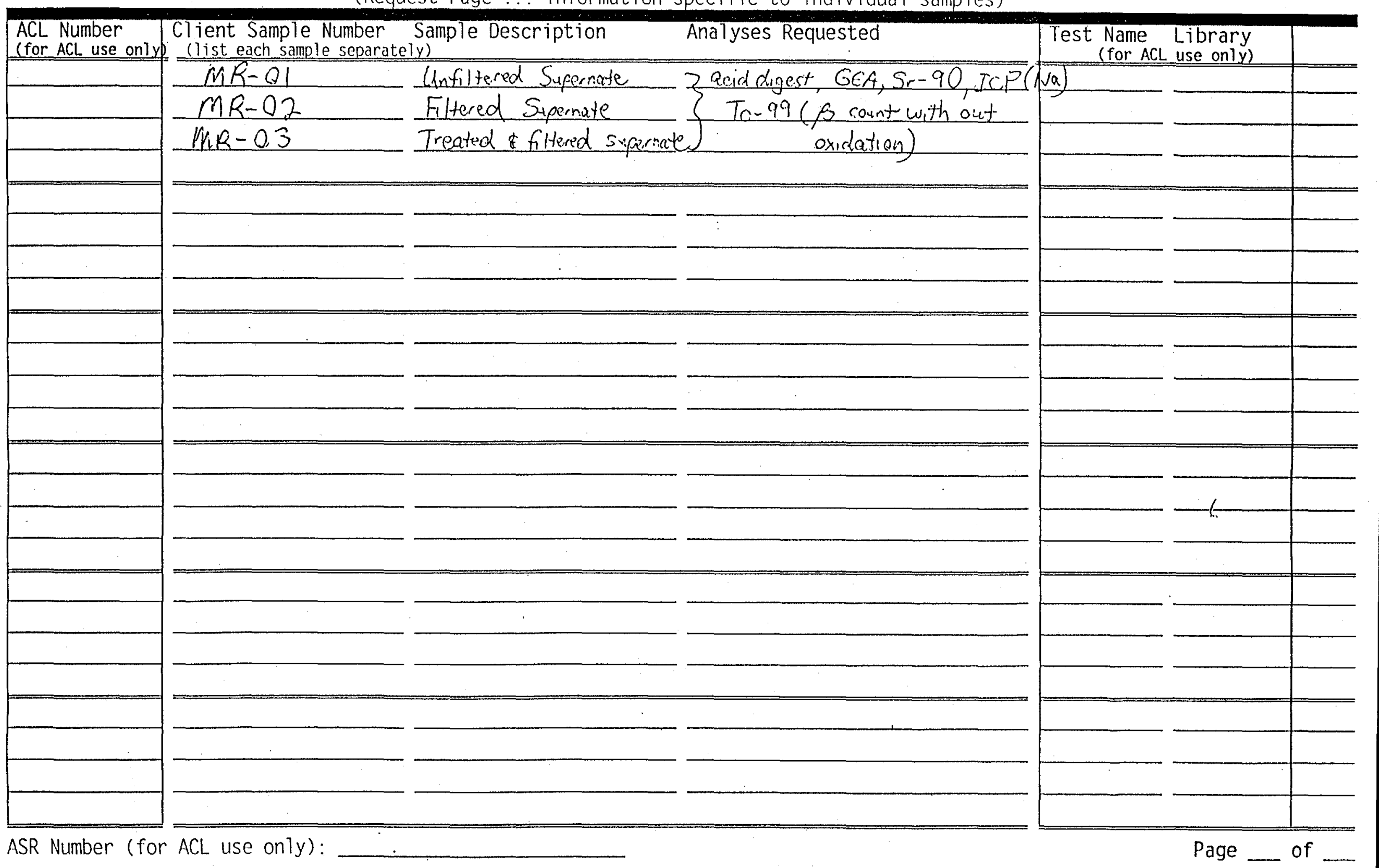


\section{Battelle PNNL/325 Bldg/RPG/Inorganic Analysis ... $\checkmark \quad$ ICPAES Data Report}

Project:

Client:
29953

K.P. Brooks
ACL Number(s): 00-0292 through 00-0294

Client ID: "MR-01" through "MR-03"

ASR Number: 5570

Total Samples: 3

Procedure: PNL-ALO-211, "Determination of Elements by Inductively Coupled Argon Plasma Atomic Emission Spectrometry" (ICP-AES).

Analyst: D.R. Sanders

Analysis Date (Filename): 11-12-99 (A0552)

See Chemical Measurement Center 98620: ICP-325-405-1 File for Calibration and Maintenance Records.

M\&TE Number:

ICPAES instrument -- WB73520

Mettler AT400 Balance -- Ser.No. 360-06-01-029

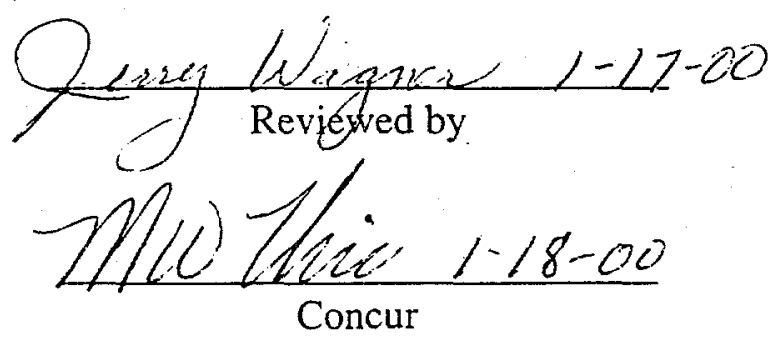




\section{Battelle PNNL/325 Bldg/RPG/Inorganic Analysis ... ICPAES Data Report}

Three radioactive aqueous samples, MR-01 through MR-03 (ACL\# 00-0292 through 00-0294) were analyzed by ICPAES after samples were processed by the Shielded Analytical Laboratory (SAL). ALO-128 acid digestion procedure was used to process the three samples and a process blank. Approximately 5 to $6 \mathrm{ml}$ sample aliquots were processed and diluted to a corrected final volume of approximately 23 to $24 \mathrm{ml}$. Sodium was the only analyte requested. Analytical dilutions of 5-fold to 50-fold were necessary due to the high concentration of sodium present in the sample.

Measurement results have been corrected for preparation and analytical dilution. Sample results are reported as $\mu \mathrm{g} / \mathrm{g}$ as requested. Weights and volumes used have been recorded on bench sheets and are included with this report. Analytes reported other than sodium are for information only.

Quality control check-standard results for sodium met tolerance requirements except as noted below. Following is a list of quality control measurement results relative to ICPAES analysis tolerance requirements under MCS-033.

Five fold serial dilution:

(Aqueous sample) All results for sodium in the diluted sample is within tolerance limit of $\leq 10 \%$ after correcting for dilution.

Duplicate RPD (Relative Percent Difference):

(Aqueous sample) Sodium is recovered within tolerance limit of $\leq 20 \%$ relative percent difference (RPD).

Post-Spiked Samples (Group A):

(Aqueous sample) Sodium was recovered within tolerance of $75 \%$ to $125 \%$.

Blank Spike:

(Aqueous sample) None.

Matrix Spiked Sample:

(Aqueous sample) None.

Quality Control Check Standards (aqueous sample):

Concentration for Sodium is within tolerance limit of $\pm 10 \%$ accuracy for QC_MCVA, ICP98.0 and QC_SSTMCV check standards.

$1 / 17 / 00$ 


\section{Battelle PNNL/325 Bldg/RPG/Inorganic Analysis ... ICPAES Data Report}

High Calibration Standard Check (aqueous sample):

Verification of the high-end calibration concentration for sodium is within tolerance of $\pm 5 \%$ accuracy.

Process Blank:

(Aqueous sample) Sodium was detected in the process blank but at a concentration less than $5 \%$ of the concentration measured in any of the samples and is within tolerance limits.

Laboratory Control Standard (LCS):

(Aqueous sample) None prepared for ALO-128 acid digestion procedure.

Please note bracketed values listed in the data report are within ten times instrument detection limit and have a potential uncertainty much greater than $15 \%$.

Comments:

1) "Final Results" have been corrected for all laboratory dilution performed on the sample during processing and analysis unless specifically noted.

2). Detection limits (DL) shown are for acidified water. Detection limits for other matrices may be determined if requested.

3) Routine precision and bias is typically $\pm 15 \%$ or better for samples in dilute, acidified water (e.g. $2 \% \mathrm{v} / \mathrm{v} \mathrm{HNO}_{3}$ or less) at analyte concentrations greater than ten times detection limit up to the upper calibration level. This also presumes that the total dissolved solids concentration in the sample is less than $5000 \mu \mathrm{g} / \mathrm{mL}(0.5$ per cent by weight).

4) Absolute precision, bias and detection limits may be determined on each sample if required by the client.

5) The maximum number of significant figures for all ICP measurements is 2 . 
Battelle PNNL/RPG/Inorganic Analysis ... ICPAES Data Report Page 1 of 1

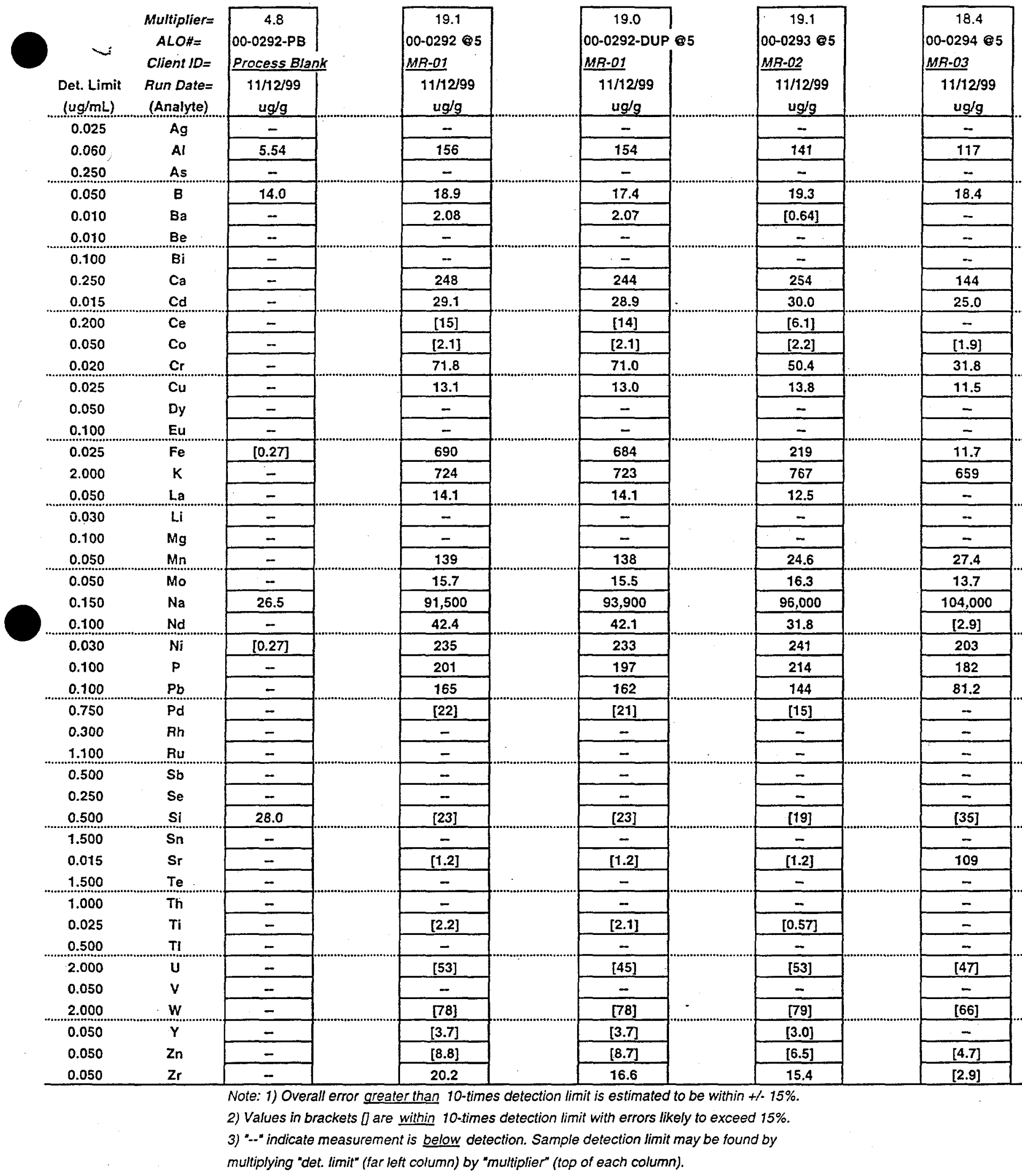




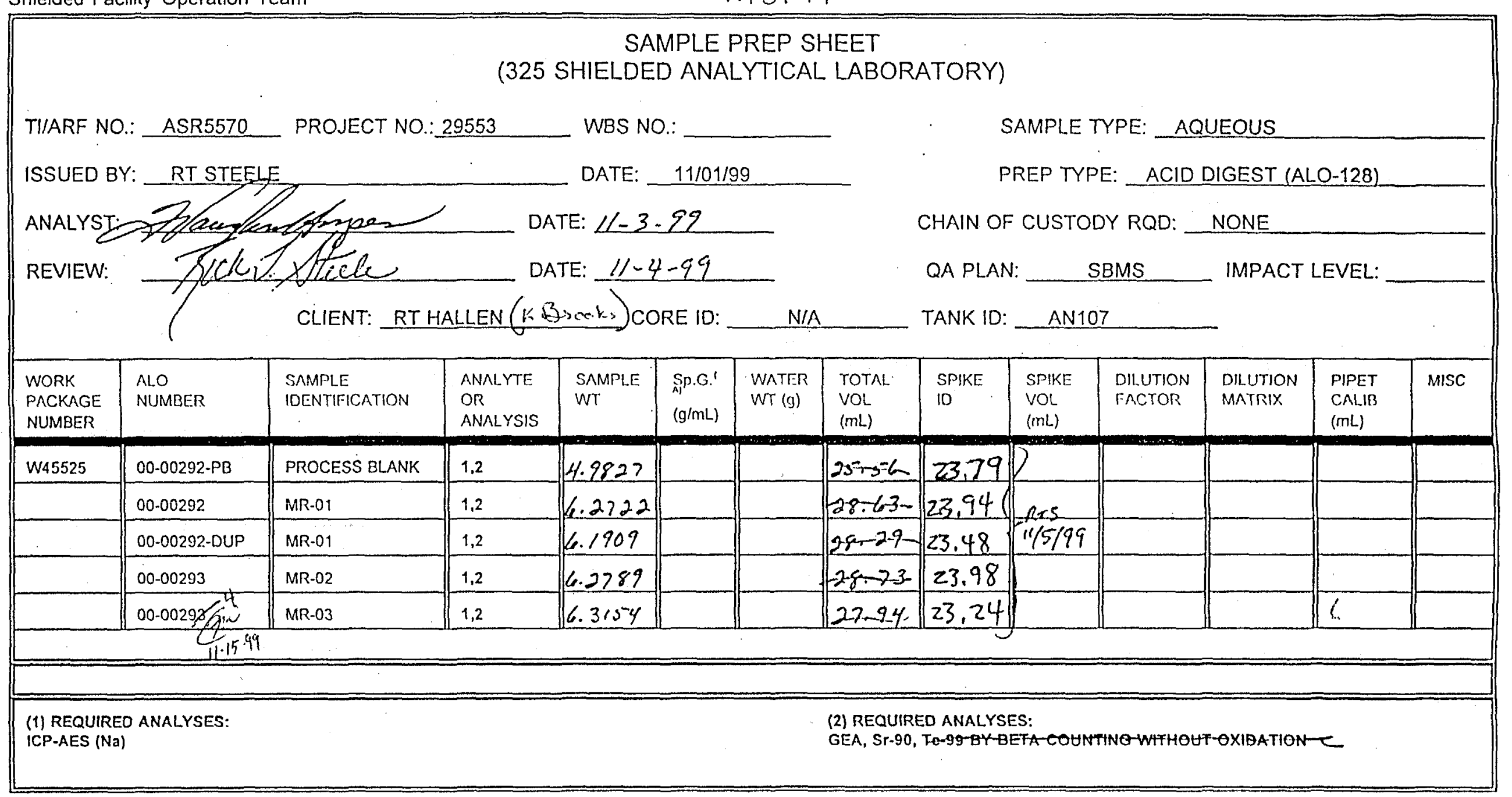


Battelle Pacific Northwest Laboratory

Radiochemical Processing Group-325 Building

Radioanalytical Applications Team

00-0292

$2 / 8 / 00$

Client: Brooks

Cognizant Scientist:

Date:

Concur :

Date :

Measured Activities (uCi/g)

\begin{tabular}{|c|c|}
\hline $\begin{array}{l}\text { ALO ID } \\
\text { Client ID }\end{array}$ & $\begin{array}{c}\text { Sr-90 } \\
\text { Error \% } \\
\end{array}$ \\
\hline $00-0292$ & $3.82 E+1$ \\
\hline MR-01 & $3 \%$ \\
\hline 00-0292DUP & $2.87 E+1$ \\
\hline MR-01 & $3 \%$ \\
\hline RPD & $28 \%$ \\
\hline $00-0293$ & $4.01 E+1$ \\
\hline MR-02 & $3 \%$ \\
\hline $00-0294$ & $9.97 E-1$ \\
\hline MR-03 & $3 \%$ \\
\hline Reagent Spike & $106 \%$ \\
\hline Blank Spike & $99 \%$ \\
\hline Blank & $\begin{array}{c}7.69 \mathrm{E}-3 \\
3 \%\end{array}$ \\
\hline
\end{tabular}

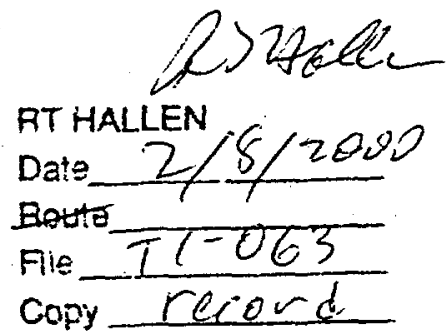


Battelle Pacific Northwest Laboratory

Radiochemical Processing Group-325 Building

Radioanalytical Applications Team

Client: Brooks

Cognizant Scientist:

ALO ID

Client ID

00-0292PB

Process Blank

00-0292

MR-01

00-0292DUP

MR-01

RPD

$00-0293$

MR-02

$00-0294$

MR-03
Concur :

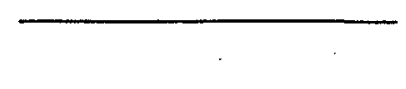

Measured Activities (uCi/g)
Date :

Date :
$2 / 8100$

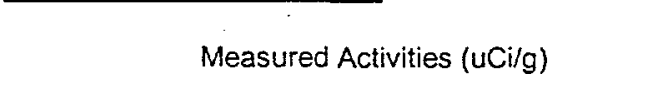

\begin{tabular}{ccccc}
$\begin{array}{c}\text { Co-60 } \\
\text { Error } \%\end{array}$ & $\begin{array}{c}\text { Cs-137 } \\
\text { Error } \%\end{array}$ & $\begin{array}{c}\text { Eu-154 } \\
\text { Error } \%\end{array}$ & $\begin{array}{c}\text { Eu-155 } \\
\text { Error } \%\end{array}$ & $\begin{array}{c}\text { Am-241 } \\
\text { Error } \%\end{array}$ \\
\hline$<3 . \mathrm{E}-5$ & $\begin{array}{c}3.52 \mathrm{E}-4 \\
6 \%\end{array}$ & $<7 . \mathrm{E}-5$ & $<7 . \mathrm{E}-5$ & $<9 . \mathrm{E}-5$ \\
& & & & \\
$6.04 \mathrm{E}-2$ & $2.06 \mathrm{E}-2$ & $2.88 \mathrm{E}-1$ & $1.93 \mathrm{E}-1$ & $2.47 \mathrm{E}-1$ \\
$4 \%$ & $13 \%$ & $2 \%$ & $6 \%$ & $11 \%$ \\
$6.33 \mathrm{E}-2$ & $2.53 \mathrm{E}-2$ & $2.77 \mathrm{E}-1$ & $1.94 \mathrm{E}-1$ & $2.72 \mathrm{E}-1$ \\
$4 \%$ & $11 \%$ & $2 \%$ & $5 \%$ & $11 \%$ \\
$5 \%$ & $20 \%$ & $4 \%$ & $1 \%$ & $10 \%$ \\
$6.27 \mathrm{E}-2$ & $2.06 \mathrm{E}-2$ & $1.73 \mathrm{E}-1$ & $1.21 \mathrm{E}-1$ & $1.49 \mathrm{E}-1$ \\
$3 \%$ & $8 \%$ & $2 \%$ & $5 \%$ & $11 \%$ \\
$5.16 \mathrm{E}-2$ & $2.08 \mathrm{E}-2$ & $2.15 \mathrm{E}-2$ & $1.51 \mathrm{E}-2$ & $1.31 \mathrm{E}-2$ \\
$4 \%$ & $10 \%$ & $9 \%$ & $17 \%$ & $25 \%$
\end{tabular}
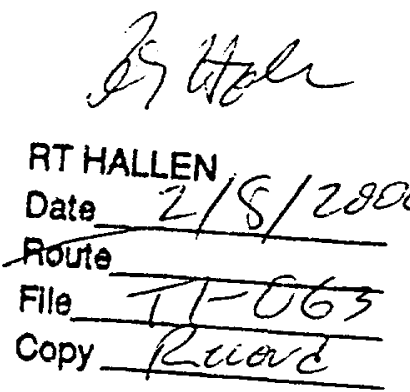
Battelle Pacific Northwest Laboratory

Radiochemical Processing Group-325 Building 00-0292

Radioanalytical Applications Team

$2 / 8 / 00$

Client: Brooks

Cognizant Scientist:

Date :

Concur :

Measured Activities (uCi/g)

ALO ID

Client ID

00-0292PB

Process Blank

00-0292

MR-01

00-0292DUP

MR-01

RPD

00-0293

MR-02

00-0294

MR-03

Reagent Spike
Date :

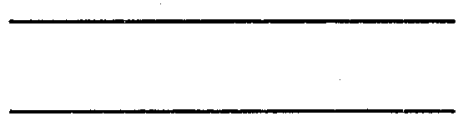

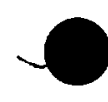




\section{Appendix D: Staff and Role/Responsibility}




\begin{tabular}{|l|l|}
\hline Staff Member & Role/Responsibility \\
\hline Richard Hallen & Scientist/Technical Leader - Sr/TRU Precipitation \\
\hline Kriston Brooks & $\begin{array}{l}\text { Engineer/CUF System, Entrained Solids Removal, Sr/TRU } \\
\text { Precipitation, and Precipitate Removal }\end{array}$ \\
\hline Lynette Jagoda & $\begin{array}{l}\text { Engineer Associate/CUF System, Entrained Solids Removal, } \\
\text { Sr/TRU Precipitation, and Precipitate Removal }\end{array}$ \\
\hline Gita Golcar & Scientist/Particle Size Analyses \\
\hline Don Rinehart & Technician/Hot Cell Tests-Sr/TRU PPT/CUF Operation \\
\hline Ralph Lettau & Technician/Hot Cell Tests-Sr/TRU PPT/CUF Operation \\
\hline Dave Ortiz & Technician/Hot Cell CUF Operation and Cleaning \\
\hline Vaughn Hoopes & Technician/Hot Cell sample prep. \\
\hline Mac Zumhoff & Technician/Hot Cell Operations \\
\hline
\end{tabular}


PNWD-3033

\section{DISTRIBUTION}

No. of

Copies

\section{OFFSITE}

No. of

Copies

\section{ONSITE}

2 DOE/Office of Scientific and Technical 5 Information
British Nuclear Fuels, Limited M. E. Johnson (4) BN-FL

A. Thompson BN-FL

14 Pacific Northwest National Laboratory

\begin{tabular}{lr}
\hline K. P. Brooks & K6-24 \\
R. T. Hallen (5) & K2-12 \\
L. K. Jagoda & K6-24 \\
D. E. Kurath & P7-28 \\
E. V. Morrey & P7-28 \\
Technical Report Files (5)
\end{tabular}

K. P. Brooks

. T. Hallen (5)

$\mathrm{K} 2-12$

K6-24

P7-28

E. V. Morrey

(5)

Distr.1 